Aus der Abteilung Hämatologie und Onkologie

(Prof. Dr. med. L. Trümper)

im Zentrum Innere Medizin

der Medizinischen Fakultät der Universität Göttingen

\title{
Etablierung der Organotypischen Hirnschnitt-Kokultur als Tumor-Invasionsmodell
}

\author{
INAUGURAL - DISSERTATION \\ zur Erlangung des Doktorgrades \\ der Medizinischen Fakultät der \\ Georg-August-Universität zu Göttingen
}

vorgelegt von

Raphaela Agatha Maria Lohaus

aus

Gladbeck

Göttingen 2013 
Dekan: Prof. Dr. med. H. K. Kroemer

I. Berichterstatterin: Prof. Dr. med. C. Binder

II. Berichterstatter: Prof. Dr. med. P. Ströbel

Tag der mündlichen Prüfung: 25. Februar 2013 


\section{Inhaltsverzeichnis}

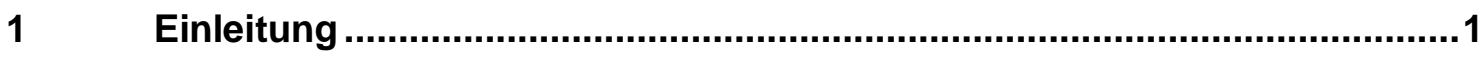

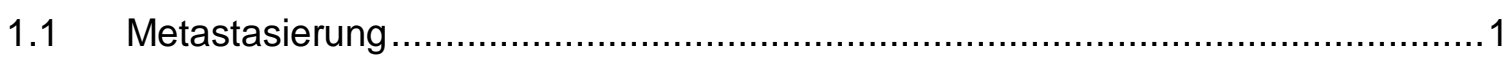

1.2 Tumor-assoziierte Makrophagen im Primärtumor ……………….......................

1.3 Die Rolle der residenten Makrophagen im Metastasenorgan ..............................

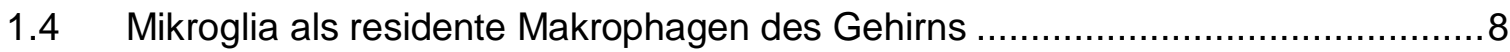

1.5 Existiert Tumor-assoziierte Mikroglia? ......................................................11

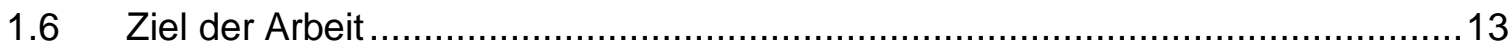

$2 \quad$ Material und Methoden ........................................................................15

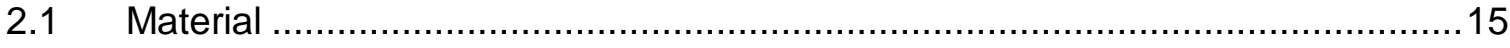

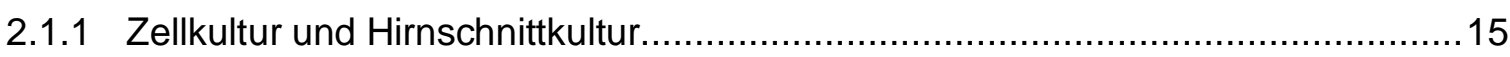

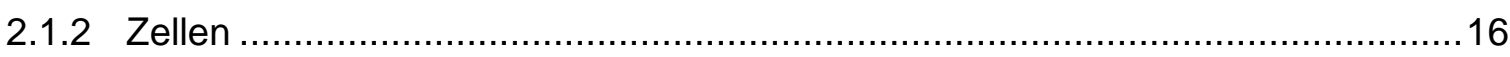

2.1.3 Stabil transfizierte Zellen ......................................................................

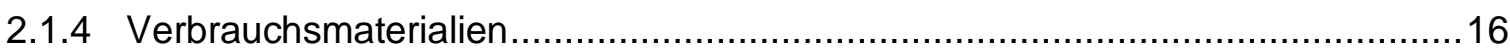

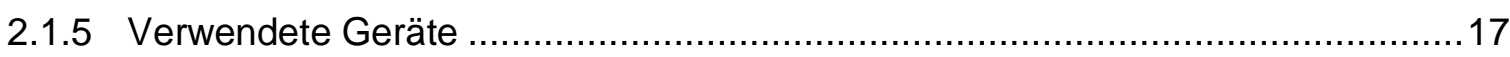

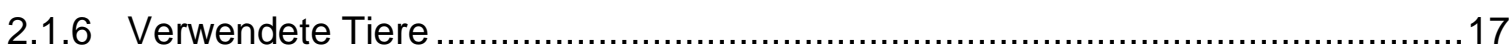

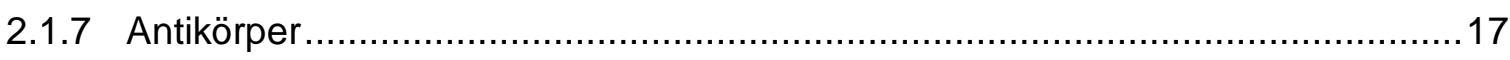

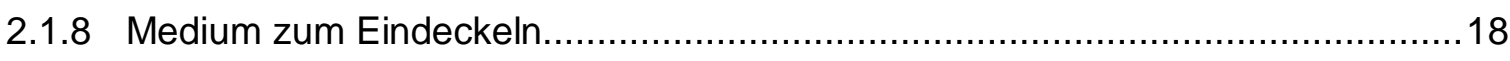

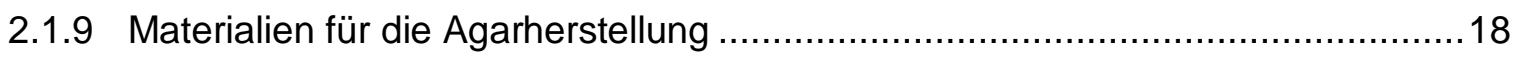

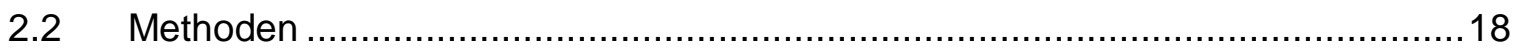

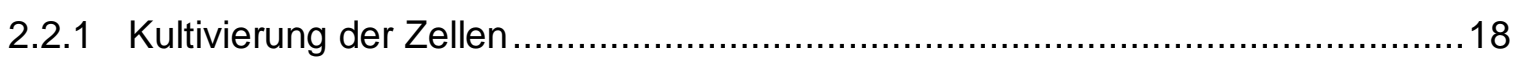

2.2.2 Auszählung der Zellen ..........................................................................19

2.2.3 Die Methode der Organotypischen Hirnschnittkultur ........................................19

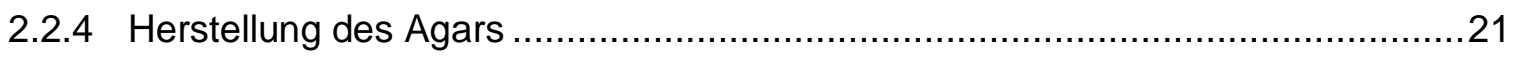

2.2.5 Herstellung des Präparationsmediums ………………………………......21

2.2.6 Herstellung des Inkubationsmediums ..........................................................21

2.2.7 Herstellung der Organotypischen Hirnschnitte ...............................................22

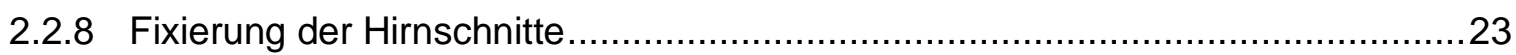

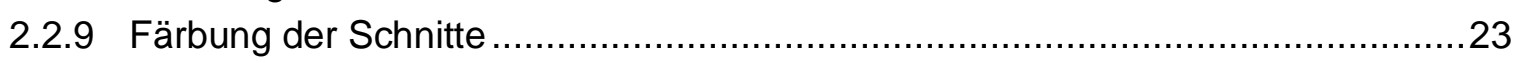

2.2.10 Auswertung der Schnitte unter dem Konfokalmikroskop .....................................23

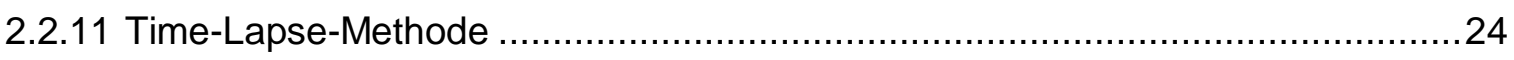

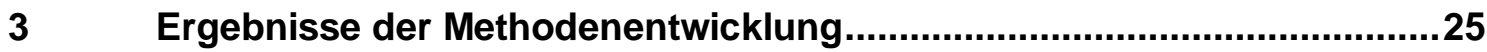

3.1 Etablierung der Organotypischen Hirnschnittkultur .........................................25

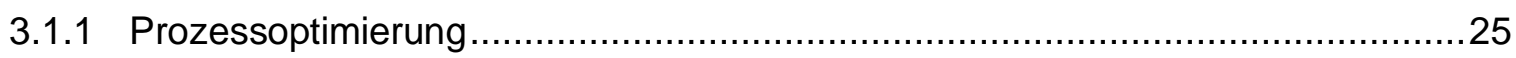

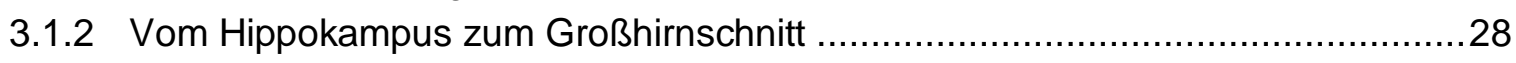

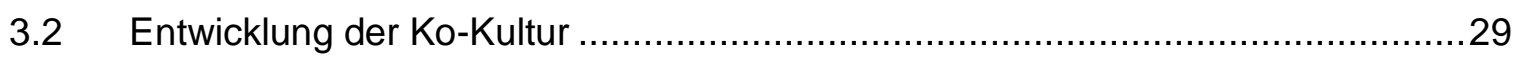

3.2.1 Die Tumorzellen werden auf dem Schnitt platziert............................................29

3.2.2 Die Tumorzellen werden auf der Membran ausgesät........................................32

3.2.3 Die Tumorzellen werden in Extrazelluläre Matrix (ECM) eingebettet ...................33 
3.2.4 Der Hirnschnitt wird beim Pipettieren des tumorzellhaltigen ECM-Tropfens abgeschirmt

3.3 Die Mikroglia werden in dem Hirnschnitt angefärbt ....................................... 36

3.4 Sichere Transferierung des Hirnschnitts auf den Objektträger ...........................36

$4 \quad$ Ergebnisse der Experimente mit Ko-Kulturen .............................................38

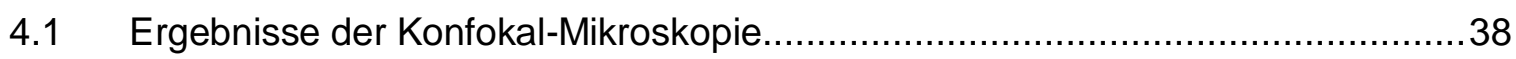

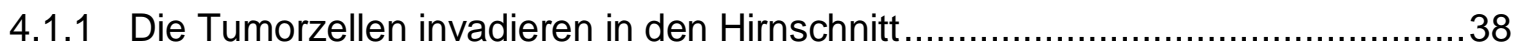

4.1.2 Mikrogliazellen sammeln sich an der Seite des Tumorzelltropfens ......................39

4.1.3 Im Kontakt mit Tumorzellen zeigen Mikroglia eine typische Morphologie ...........41

4.1.4 Mikroglia invadieren in den Tumorzelltropfen ...............................................4 43

4.1.5 Mikroglia ebnen den Tumorzellen den Weg in das Hirngewebe .........................43

4.2 Ergebnisse der Time-Lapse-Mikroskopie: Der „tödliche Kuss“ der Mikroglia.......45

$5 \quad$ Diskussion der Methodenentwicklung .........................................................48

5.1 Etablierung der Organotypischen Hirnschnittkultur .....................................48

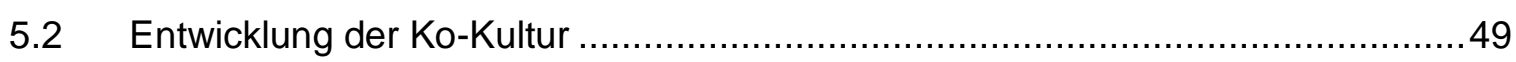

5.2.1 Ausäen der Tumorzellen auf der Membran...................................................51

5.2.2 Einbettung der Tumorzellen in einen ECM-Gel-Tropfen....................................51

5.2.3 Abschirmung des Hirnschnitts beim Platzieren der Tumorzellen..........................53

5.2.4 Wie kann residente Mikroglia von eingewanderten Blutmakrophagen unterschieden werden?....

6 Diskussion der Ergebnisse der Konfokal- und Time-Lapse-

Mikroskopie............................................................................................56

6.1 Interaktionen zwischen Tumorzellen und Mikroglia im Konfokal-Mikroskop ........56

6.1.1 Mikroglia sammelt sich in der Nähe der Tumorzellen........................................56

6.1.2 Mikroglia in Kontakt mit Tumorzellen zeigt eine typische Morphologie................56

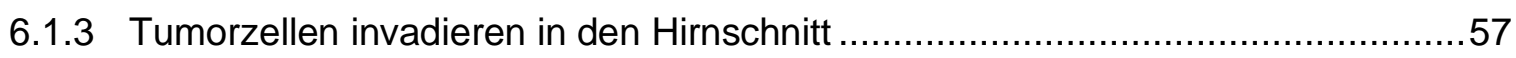

6.1.4 Mikroglia invadiert in den Tumorzell-ECM-Tropfen ..........................................58

6.1.5 Mikroglia bahnt den Tumorzellen den Weg in das Hirngewebe ..........................58

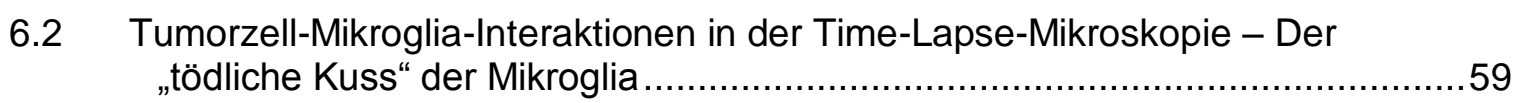

6.3 Chancen und Grenzen für weitere Untersuchungen mit der entwickelten Ko-

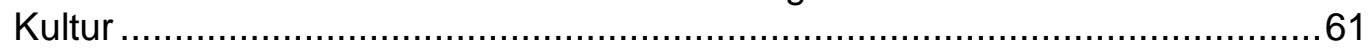

$7 \quad$ Abgeleitete Thesen zur Tumorinvasion ...................................................63

7.1 Mikroglia im Zusammenhang mit dem Wnt-5a-Signalweg ..............................63

7.2 Inhibition der Mikroglia durch Bisphosphonate............................................64

7.3 Ko-Kultur des Organotypischen Hirnschnittes mit einer benignen Zelllinie..........64

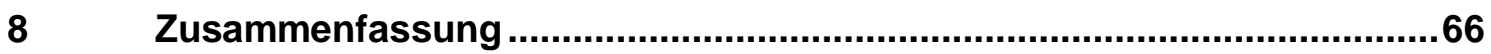

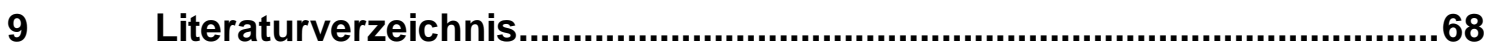

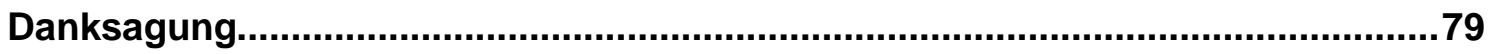

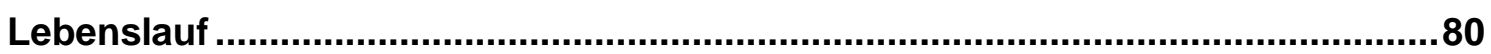




\begin{tabular}{|c|c|}
\hline ACSF & Artificial Cerebrospinal Fluid \\
\hline APC & Antigen-Presenting Cell \\
\hline BSA & Bovine Serum Albumin \\
\hline CAM & Cell Adhesion Molecules \\
\hline CD & Cluster of Differentiation \\
\hline CSF & Colony-Stimulating-Factor \\
\hline DAPI & 4', 6-Diamidin-2-Phenylindol \\
\hline DKK & Dickkopf \\
\hline DMEM & Dulbecco's Modified Eagle Medium \\
\hline ECM & Extracellular Matrix \\
\hline EDTA & Ethylenediaminetetraacetic Acid \\
\hline EGFP & Enhanced Green Fluorescent Protein \\
\hline EHS & Engelbreth-Holm-Swarm Sarkoma Cells \\
\hline EMT & Epithelial-Mesenchymal-Transition \\
\hline FCS & Fetale Calf Serum \\
\hline HBSS & Hank's Buffered Sodium Solution \\
\hline IL & Interleukin \\
\hline INF & Interferon \\
\hline JNK & c-jun N-Terminal-Kinase \\
\hline LPS & Lipopolysaccharid \\
\hline LRP & Low Density Lipoprotein Receptor Related Protein \\
\hline MCF-7 & Michigan Cancer Foundation-7 \\
\hline MCP-1 & Monocyte Chemoattractant Protein-1 \\
\hline MEM & Minimal Essential Medium \\
\hline MG & Mikroglia \\
\hline $\mathrm{MHC}$ & Major Histocompatibility Complex \\
\hline MMP & Matrixmetalloproteinase \\
\hline $\mathrm{NF}_{\mathrm{K}} \mathrm{B}$ & Nuclear Factor ${ }_{k} B$ \\
\hline NGS & Normal Goat Serum \\
\hline NHS & Normal Horse Serum \\
\hline NK Zelle & Natural Killer Cell \\
\hline NMRI & Naval Medical Research Institute \\
\hline NO & Nitric Oxide \\
\hline PBS & Phosphate Buffered Saline \\
\hline PFA & Paraformaldehyd \\
\hline RPM & Revolution per Minute \\
\hline
\end{tabular}




$\begin{array}{ll}\text { RPMI } & \text { Roswell Park Memorial Institute } \\ \text { TAM } & \text { Tumor-associated Makrophages } \\ \text { TNF- } \alpha & \text { Tumor Necrosis Factor } \alpha \\ \text { Wnt } & \text { Wingless Type MMTV Integration Site }\end{array}$




\section{$1 \quad$ Einleitung}

\section{$1.1 \quad$ Metastasierung}

Die Krebserkrankung stellt in den industrialisierten Ländern nach der HerzKreislauferkrankung die zweithäufigste Todesursache dar. Die Mortalität wird im Wesentlichen durch die Ausbildung von Tochtergeschwülsten, Metastasen, bestimmt. Von besonderem Interesse sind hierbei Hirnmetastasen, da die Tumorzellen offensichtlich in der Lage sind, die Blut-Hirnschranke zu überwinden, die für andere im Blut befindliche Zellen oder gelöste Stoffe in der Regel unpassierbar ist. Die Relevanz wird besonders an Hand der Entwicklung von Hirnmetastasen bei Patienten mit der Erstdiagnose Brustkrebs deutlich. Etwa 5,1\% dieser Patienten werden im Laufe ihrer Erkrankung Hirnmetastasen entwickeln und verfügen von da an nur noch über eine mediane Überlebenszeit von 5,6 Monaten (Barnholtz-Sloan et al. 2004, Lee et. al 2008).

Zu Beginn steht die Tumor-Initiation, ausgelöst durch eine genetische Instabilität einer ersten Krebszelle. Nach dem Modell der Karzinogenese von Hanahan und Weinberg erlangen die Tumorzellen durch die Veränderungen im Genom folgende entscheidende Eigenschaften:

1. das Potential zur grenzenlosen Replikation

2. die Unabhängigkeit gegenüber steuernden Wachstumssignalen

3. das Umgehen des programmierten Zelltodes, der Apoptose

4. eine ausreichende Blutversorgung der wachsenden Zellen durch anhaltende Angiogenese

5. die Invasion der malignen Zellen in das benachbarte Gewebe (Hanahan und Weinberg 2000).

Die Metastasierung ist ein vielschichtiger Prozess, der auf das feine Zusammenspiel vieler kleiner Einzelvorgänge angewiesen ist. Nach dem 4-schrittigen Modell der Tumor-Progression (de Nardo et al. 2008) bedarf es für die Entstehung einer Tochtergeschwulst der lokalen Invasion des Tumors, der Intravasation in den Blutkreislauf, der Extravasation und schließlich der Ansiedlung und Proliferation im neuen Gewebe, dem Metastasenorgan. Über die Einwanderung in die Gefäße 
erschließen sich die Tumorzellen den Weg in den systemischen Blutkreislauf. Mit dem Blutkreislauf können sie nun in alle Regionen des Körpers gelangen. Um zu einer Metastase zu werden, müssen die neoplastischen Zellen den Blutkreislauf an einer Stelle wieder verlassen. Sie treten in einem fremden Organ aus den Blutgefäßen aus und beginnen, in dem neuen Gewebe zu wachsen. Dank der Forschung der letzten 10 Jahre wurde deutlich, dass die Krebszelle - um bis hierhin zu gelangen - zusätzliche essentielle Fähigkeiten benötigt. Hanahan und Weinberg erweitern daher ihre Liste der „Hallmarks of Cancer“ um zwei weitere entscheidende Punkte:

1. die Tumorzellen programmieren ihren Metabolismus hin zur aeroben Glykolyse (Warburg-Effekt)

2. die Krebszelle entgeht dem Immunsystem

(Hanahan und Weinberg 2011).

In welchem Organ des Körpers die malignen Zellen den Blutkreislauf wieder verlassen, ist nicht dem Zufall überantwortet. Das erkannte bereits Paget im ausgehenden 19. Jahrhundert. Bei seiner Untersuchungsreihe von 735 Patientinnen mit Brustkrebs stellte er fest, dass überdurchschnittlich häufig die Leber als Metastasenorgan betroffen war. Dies führte inn zu seiner „Seed and Soil Hypothese“. Er verglich die Dissemination von Tumorzellen mit den Samen einer Pflanze. Die Samen werden in alle Himmelsrichtungen verteilt. Damit der Samen jedoch aufgehen, wachsen und gedeihen kann, muss er auf fruchtbaren Boden fallen (Paget et. al 1889). Gleichsam benötigt auch eine Tumorzelle einen geeigneten Nährboden. Heute ist allgemein bekannt, dass jeder Tumortyp bevorzugte Metastasenorgane aufweist. Häufig sind dabei die Leber, Lunge, der Knochen oder das Gehirn betroffen.

In den einzelnen Schritten der Tumorentstehung und Progression spielt das Mikromilieu des Tumors eine entscheidende Rolle. Dieses den Tumor umgebende Stroma ist reich an benignen Zellen, wie Endothelien, Fibroblasten und Zellen der Immunabwehr, beispielsweise B- und T-Lymphozyten, NK-Zellen, APC-Zellen, neutrophile Granulozyten oder Makrophagen. Diese Stromazellen vermögen es, zum Beispiel durch Proteasen einen Gewebeumbau zu bewirken oder durch die Sezernierung von Wachstumsfaktoren bzw. angiogenetischen Faktoren die Proliferation und die invasiven Eigenschaften der neoplastischen Zellen zu fördern (de Nardo et al 2008). Ein Teil dieses Mikromilieus bilden die Tumor-assoziierten Makrophagen (TAM). Es konnte gezeigt werden, dass TAM die Fähigkeit besitzen, die Proliferation, die Invasion sowie die Intravasation der Tumorzellen zu fördern. Des 
Weiteren induzieren eben diese Makrophagen den Gewebeumbau und die Neubildung von Gefäßen (Balkwill et al. 2005, Biswas et al. 2008, Condeelis und Pollard 2006, Mantovani et al. 2008, Pollard 2009).

Bisher konnte die oben beschriebene Rolle der TAM vor allem für die Schritte Invasion und Intravasation gezeigt werden. Ob und wieweit die Makrophagen ebenfalls entscheidend für die Extravasation und Kolonisation der malignen Zellen im Metastasenorgan sind, ist bislang unklar. Um diese Effekte weiter zu diskutieren, soll im Folgenden zunächst die Arbeitsweise der Makrophagen beleuchtet werden.

\subsection{Tumor-assoziierte Makrophagen im Primärtumor}

Im Jahre 1863 machte Rudolf Virchow in seinen histopathologischen Untersuchungen die Entdeckung, dass sich in neoplastischem Gewebe Leukozyten befanden (Balkwill und Mantovani 2001). Aus dieser Beobachtung heraus leitete Virchow die These ab, dass es zur Enstehung eines Tumors einer lokalen Prädisposition bedarf, die durch ein leukoretikuläres Infiltrat gekennzeichnet ist (Hauptmann und Schnalke 2001, S. 292). Klemm erläutert in seiner Arbeit, dass die Betrachtungsweise Virchows in den letzen Jahren eine Renaissance erfährt (Klemm 2010). Das leukoretikuläre Infiltrat Virchows spiegelt sich in der Auffassung wider, dass vor allem eine chronische, schwelende Inflammation Malignität fördert und unterhält (Balkwill und Mantovani 2001). Heute gibt es eine Vielzahl weiterer Hinweise, die die Verknüpfung von Inflammation und Neoplasie belegen, wobei diese sich sowohl auf die Initiation als auch auf die Tumorprogression beziehen. Als prominentes Beispiel für Ersteres kann hier der Zusammenhang zwischen Zervix-Karzinom und humanen Papillomaviren angeführt werden. Im Jahre 1983/1984 wurden die HPV-Typen 16 und 18 entdeckt, die von der Arbeitsgruppe um zur Hausen eindeutig als Verursacher des Zervix-Karzinoms identifiziert werden konnten (zur Hausen 2008). Wenige Jahrzehnte danach steht jungen Frauen weltweit auf Grundlage dieser Forschung eine Impfung zur Vorbeugung der Entstehung der präkanzerösen Vorstufe des Zervix-Karzinoms zur Verfügung.

Für die Tumorentstehung spielt die chronische subklinische Inflammation eine entscheidende Rolle. Chronische Entzündungen, wie beispielsweise bei mikrobiellen Infektionen oder Autoimmunerkrankungen, steigern das Risiko der Krebsentstehung. Etwa 15-20\% aller tödlich verlaufenden Krebsleiden gehen auf eine chronische Entzündung zurück (Mantovani et al. 2008). In diesem Zusammenhang erscheint es 
nicht verwunderlich, dass für nicht-steroidale Antirheumatika, wie Aspirin, ein protektiver Effekt zur Krebsentstehung berichtet wird (Koehne und Dubois 2004, Flossmann und Rothwell 2007, Chan et al. 2008).

Die Schlüsselzelle für solche chronischen Entzündungen ist die Makrophage, speziell die sogenannte Tumor-assoziierte Makrophage (TAM). (Balkwill et al. 2005). Diese Zellen finden sich in unterschiedlichem Ausmaß in jedweder Art von Tumoren. Dabei differenzieren sich die TAM aus monozytischen Vorläuferzellen aus. Die Monozyten migrieren aus dem Knochenmark in den Blutstrom, wo sie mit einer Halbwertzeit von 24 Stunden zirkulieren (Leek und Harris 2002). Gelenkt durch Mediatoren, wie Chemokine, Zytokine und Prostaglandine, wandern die Monozyten in das Tumorstroma ein und differenzieren zu Makrophagen. Ein Beispiel für von Tumorzellen sezernierte Chemokine ist das Monocyte Chemoattractant Protein-1 (MCP-1), welches die Monozyten aus dem Blutstrom in das Tumorstroma lockt (Mantovani et al. 2004, Klemm 2010). Dabei ist es interessant, dass MCP-1 auch das Signal für Monozyten und T-Zellen darstellt, die Blut-Hirnschranke zu überwinden und in das Hirnparenchym zu migrieren (Bechmann et al. 2006, Sozzani et al. 1995, Rollins 1996). Neben Chemokinen können Tumorzellen ebenfalls Colony-stimulating-Factor (CSF) sezernieren. CSF fördert das Überleben der TAM im neoplastischen stromalen Kompartiment (Balkwill und Mantovani 2001).

Als Teil der angeborenen Immunabwehr besitzen TAM potentiell die Fähigkeit, die entartete Zelle zu zerstören. Daneben verfügen diese Makrophagen auch über die Eigenschaft, Wachstums- und angiogenetische Faktoren zu produzieren sowie proteolytische Enzyme freizusetzen, die die Extrazelluläre Matrix (ECM) degradieren. Infolgedessen besitzen TAM neben den tumoriziden Funktionen auch Werkzeuge, die das Tumorzellwachstum, die Neubildung von Gefäßen sowie die Invasion und Metastasierung fördern (Balkwill und Mantovani 2001). Beispielsweise konnte für das Mamma-Karzinom nachgewiesen werden, dass der Kontakt mit Tumor-assoziierten Makrophagen eine Invasionssteigerung bewirkt und über Zytokine und MMP-Sekretion die Invasion der malignen Zellen fördert (Hagemann et al. 2004). Beim MammaKarzinom konnte eine hohe Anzahl infiltrierender TAM als eigenständiger Faktor einer geringeren Überlebenswahrscheinlichkeit zugeschrieben werden (Leek et al. 1996, Leek und Harris 2002). Mäuse mit einem Mamma-Karzinom und gleichzeitig defekter Makrophagen-Reifung bildeten weniger häufig Metastasen als Mäuse, deren Makrophagen-Reifung intakt blieb (Lin et al. 2001). 
TAM unterscheiden sich von inflammatorisch aktivierten Makrophagen mit einem klassischen M1-Profil von sezernierten Zytokinen durch die Ausbildung eines sogenannten M2-Phänotypes.

Man kann also bei der Vielfalt von polarisierenden Eigenschaften grundsätzlich zwei Funktionsprogramme bei den TAM unterscheiden. Die Ausbildung des Subtyps M1 oder M2 geschieht dabei jeweils in Abhängigkeit von Signalen des umgebenden Kompartimentes (Balkwill et al. 2005). Wie erwähnt, charakterisiert in der dichotomen Nomenklatur der M1-Typ die „klassische“ Entzündungsreaktion, wohingegen der Terminus M2-Makrophage für eine Vielzahl alternativer Aktivierungsmöglichkeiten eingeführt wurde (Mantovani et al. 2004). Während die M1-Makrophage zytotoxische Funktionen ausübt und somit potentiell antitumorös wirkt, unterhält die M2-Makrophage eine chronische Entzündung mit einhergehendem Gewebeumbau und Aussprossung neuer Gefäße (Mantovani et al. 2004, Sica et al. 2006).

Die M1-Makrophage wird durch mikrobielle Reize wie das Lipopolysaccharid (LPS) sowie durch Interferon $\gamma$ aktiviert (Allavena et al. 2008). Über den ArgininMetabolismus produzieren diese Zellen Stickstoffmonoxid und reaktive Sauerstoffspezies, die zur Abtötung von Pathogenen führen (Mantovani et al. 2004). Mit ihrem Aufgabenspektrum stehen diese M1-Zellen im Dienst der Tumorabwehr.

Durch Stimuli wie z.B. IL-4, IL-13, IL-10, IL-21, CSF, wird die Differenzierung in M2Makrophagen getriggert. Diese Zellen fördern unter anderem die Zellproliferation durch Sekretion von Wachstumsfaktoren und Produktion von Ornithin und Polyaminen über ihren Arginase-Stoffwechsel. Sie induzieren Angiogenese sowie das sogenannte Tissue remodelling (Mantovani et. al. 2004, Allavena et. al. 2008). M2-Zellen dienen somit der Tumorpromotion. Während die M1-Zellen durch ein hohes IL-12- und niedriges IL-10-Profil gekennzeichnet sind, zeigen M2-Zellen genau das Gegenteil, ein niedriges Level von IL-12 und ein hohes von IL-10 (Allavena et al. 2008). In malignen Prozessen sind überwiegend Tumor-assoziierte Makrophagen (TAM) vom M2-Typ beteiligt (Balkwill et al. 2005). Das dabei für den M2-Typ charakteristische IL-10 unterbindet eine Differenzierung der Makrophagen in M1-Makrophagen. Dadurch wird die potenziell tumorizide Makrophage gehemmt und das Gleichgewicht in Richtung der für die Tumorzellen vorteilhaften M2-Zelle verschoben. Dabei ist der Übergang von M1in eine M2-Makrophage fließend. 


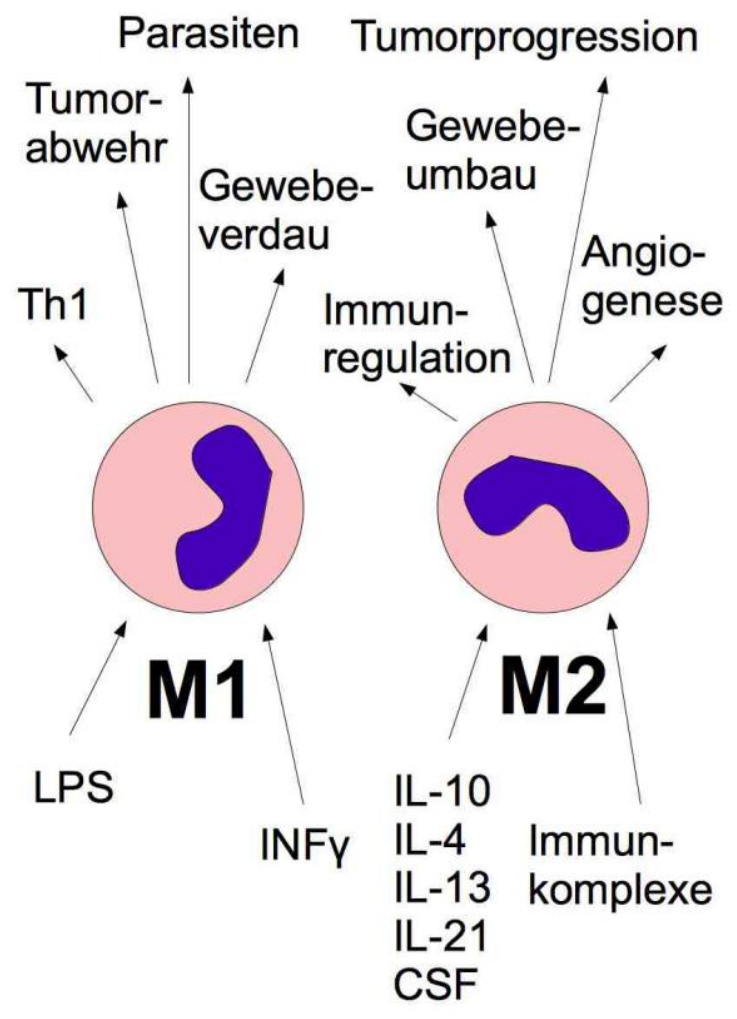

Abbildung 1.1 Vereinfachter Überblick über die Polarität von M1- und M2- Makrophagen (nach Allavena et. al 2008, S. 156) Klassische Makrophagen vom M1-Typ werden über INF $\gamma$ oder über das mikrobielle Stimulus LPS, der M2-Typ hingegen über IL-10, 4, 13, 21, CSF oder über Immunkomplexe aktiviert. Die M1- Makrophage steht im Dienst der Tumorabwehr. Sie vermag es, Th1-Zellen zu stimulieren, Gewebe zu verdauen und sie ist für die Beseitigung von Parasiten zuständig. Demgegenüber fördert die M2-Makrophage die Tumorprogression. Der M2-Typ induziert Angiogenese, bewirkt eine Neuorganisation von Gewebe und ist in der Lage, die Immunabwehr zu modulieren.

M2-TAM produzieren in niedrigen Konzentrationen TNFa, welches invasionssteigernde Effekte aufweist. Hagemann et. al. konnten zeigen, dass durch TNFa über die Phosphorylierung von c-jun N-terminal-kinase (JNK) und über den Stoffwechselweg des nuclear factor ${ }_{k} B\left(\mathrm{NF}_{k} \mathrm{~B}\right)$ die Invasivität von epithelialen Tumorzellen gesteigert wird (Hagemann et al. 2004, Hagemann et al. 2005, Hagemann et al. 2008). Pukrop et al. konnten in dem Zusammenhang die Bedeutung des Wnt-Signalweges klären. Eine Hochregulation von Wnt 5a kann ebenfalls eine JNK-vermittelte Invasion induzieren, die durch den Wnt-Inhibitor Dickkopf aufgehoben werden kann (Pukrop et al. 2006, Klemm 2010). 


\subsection{Die Rolle der residenten Makrophagen im Metastasenorgan}

Gemäß dem vier Stufen-Modell der Tumorprogression (de Nardo et al. 2008) ist bisher lediglich bekannt, dass Makrophagen entsprechend ihrer im vorherigen Kapitel beschriebenen Funktionen zu den ersten beiden Schritten der Ausbreitung der Tumorzellen und deren Eindringen in umliegende Gefäße beitragen. Jedoch ist es bisher völlig unklar, ob die tumorfördernden Eigenschaften der Makrophagen ebenfalls in den entscheidenden Phasen der Extravasation und des Wachstums der Krebszellen im Metastasenorgan eine Rolle spielen. Insbesondere ist ungeklärt, ob dabei die Population der ortsständigen, organspezifischen Makrophagen eine ähnliche Funktion wie die aus dem peripheren Blut einwandernden TAM ausüben. Darüber hinaus stellt sich die Frage, ob ortsständige Makrophagen ihre möglichen proinvasiven Effekte ebenfalls über eine M2-Polarisierung vornehmen. Einige Arbeiten weisen auf eine ähnliche Funktion der ortsständigen Makrophagen für diese Schritte in der Metastasenbildung hin. Es gibt Hinweise, dass sich durch Depletion der Makrophagen entscheidend die Ausbreitung der Tumorzellen reduzieren lässt (Halin et al. 2009, Hiraga et al. 2004, Padalecki und Guise 2002, Robinson-Smith et al. 2007, Tuomela et al. 2008)

Wenn Tumorzellen durch Intravasation in den Blutkreislauf gelangen, schaffen es nur sehr wenige dieser Zellen, den Blutkreislauf wieder zu verlassen und sich in einem anderen Organ nieder zu lassen. Warum besitzen einige Tumorzellen die Eigenschaft, ein Tochtergeschwulst zu bilden, und andere wiederum nicht? Es scheinen zusätzliche Bedingungen unabdingbar, damit aus einer Tumorzelle auf Wanderschaft ein neuer Tumor entstehen kann (Foskas et al. 2007).

Des Weiteren können Tumorzellen sich nicht in jedem beliebigen Organ des Körpers absiedeln. Es scheint mehr oder weniger geeignete Organe zu geben, die den malignen Zellen fruchtbaren Boden bieten. Typische Metastasenorgane sind die Leber, die Lunge, die Knochen und das Gehirn. All diese vier Organe verfügen über gewebespezifisch differenzierte Monozyten, die residenten Makrophagen. In der Leber finden sich Kupffer-Sternzellen, in der Lunge Alveolarmakrophagen, in den Knochen Osteoklasten und im Gehirn Mikroglia-Zellen als differenziertes Korrelat myeloider Vorläuferzellen. Unter diesen Gesichtspunkten stellt sich die Frage, ob nicht diese residenten Makrophagen gleichsam den Schlüssel für die Tumorzellen darstellen, der innen den Zugang zum Metastasenorgan öffnet. Die Datenlage zu dieser Hypothese ist 
immer noch sehr spärlich. Weiterhin ist es nicht ausreichend geklärt, wie die tumorösen Zellen die Blut-Hirnschranke überwinden können.

\subsection{Mikroglia als residente Makrophagen des Gehirns}

Mikroglia sind die residenten Makrophagen des zentralen Nervensystems (ZNS). Sie wurden zuerst von P. del Rio-Hortega in den 30er Jahren beschrieben. P. del RioHortega skizzierte die Mikrogliazellen als eine eigenständige Zellpopulation des ZNS, die sich von der bis dato bekannten Glia (Astrozyten) sowie den Nervenzellen des Gehirns unterschieden. Diese Beobachtung war inm auf Grund seiner neu entwickelten Silberkarbonat-Färbung gelungen, die spezifisch Mikroglia anfärbte (Del Rio-Hortega 1932).

Die Herkunft der Mikroglia ist Gegenstand von Diskussionen. Aktuelle Daten weisen darauf hin, dass es sich um Zellen mesenchymalen Ursprungs handelt, die das Neuroektoderm des Hirngewebes in der Embryonalentwicklung besiedeln (Hanisch und Kettenmann 2007). Dabei findet die Einwanderung der mikroglialen Vorläuferzellen in zwei Phasen statt. Die erste Welle erfolgt während der fetalen Entwicklung, beim Menschen in den ersten zwei Trimestern und beim Nagetier um den Embryonaltag 10 bis 19 (Hanisch und Kettenmann 2007). Die mikroglialen Vorläuferzellen sind fetale Makrophagen, die aus monozytären Vorläuferzellen des Blutes stammen und von den Leptomeningen aus über die Ventrikelzone oder über frühe Blutgefäße in das Gehirn einwandern (Streit und Xue 2009). Neue Hinweise lassen erkennen, dass mikrogliäre Zellen hervorgehend aus myeloischen Progenitorzellen sogar noch früher, nämlich bereits vor dem 8. Embryonaltag, erscheinen (Ginhoux et al. 2010). Dabei zeigte die Arbeitsgruppe um Ginhoux, dass Mikroglia sich auch in dem Gehirn von Mäusen entwickeln, die für den Faktor Colony-Stimulating-1 (CSF-1) defizient sind, dass hingegen Mikroglia in Gehirnen von Mäusen fehlen, die einen Defekt im CSF-1Rezeptor aufweisen (Ginhoux et al. 2010). Mikrogliäre Vorläuferzellen akkumulieren im Zellverband in spezifischen Teilen des Gehirns. Vor allem ist hier das Corpus callosum zu nennen (Ling E und Wong 1993). Eine zweite Invasionswelle von Mikrogliazellen ins ZNS findet in der zweiten postnatalen Woche statt. Hierbei nehmen die Mikrogliazellen eine typische Morphologie ein, die ebenfalls bereits von Rio-Hortega beschrieben wurde. Ihr abgerundeter Zellleib und das Fehlen von Ausläufern haben ihnen den Namen „amöboid“ verliehen. Die amöboiden Zellen proliferieren, wandern über Kortex und Nervenfaserbündel in alle Regionen des Gehirns und differenzieren dabei zu voll 
ausgereifter ramifizierter Mikroglia (Bechmann et al. 2006). Am Ende der Gehirnentwicklung haben die Mikrogliazellen sich im gesamten ZNS ausgebreitet, einschließlich in der Retina (Hanisch und Kettenmann 2007). Im erwachsenen Gehirn machen die Mikroglia etwa 5-20\% der glialen Population aus, das bedeutet, dass sich im Gehirn etwa genauso viele Mikroglia- wie Nervenzellen befinden (Bechmann et al. 2006).

Unter physiologischen Bedingungen spricht man von ruhender Mikroglia mit einem ramifizierten Äußeren. Ramifizierte Mikroglia besitzen einen schmalen Zellleib mit vielen, stark verzweigten Ausläufern, die der Zelle ein spinnenartiges Aussehen verleihen (Czapiga and Colton 1999). Der Ausdruck „ruhend“ mag irreführend klingen, denn bei der ruhenden Mikroglia handelt es sich um alles andere als um schlafende oder inaktive Zellen. Hanisch und Kettenmann bevorzugen deshalb den Begriff „surveying“ Mikroglia, die einem Wächter gleich die Homoöstase des Hirnparenchyms unter ruhenden, physiologischen Bedingungen kontrollieren. Die Mikrogliazellen agieren als Sensoren für jedwede Art von pathologischen Ereignissen im ZNS (Kreutzberg 1996). Ramifizierte Mikroglia sind hochaktiv und beweglich. Ihre Zellausläufer und filopodienartigen Protrusionen befinden sich im ständigen Umbau. Durch diese dynamische und zugleich vorsichtige Reorganisation ihres Zellkörpers vermögen die Mikroglliazellen ihre Umgebung zu überprüfen, ohne dabei das empfindliche und fragile Netz der Nervenzellen zu stören (Hanisch und Kettenmann, 2007). Neben der Überwachung der Homoöstase des ZNS obliegt es dem Aufgabenbereich der Mikroglia, apoptotische Zellen zu beseitigen oder auch Apoptose zu induzieren (Bessis et al. 2007, Streit et al. 2001). Sie sind zuständig für den Gewebeumbau während der Entwicklungsphase des Gehirns (Pollard et al. 2009).

Des Weiteren übernehmen sie den Schutz der Nervenzellen durch Produktion von Wachstumsfaktoren, Zytokinen und Neurotrophinen; sie phagozytieren den Zellschrott und sorgen für die Wiederaufnahme von Glutamat (Streit et al. 2009). Zudem stellen Mikroglia die Immunzellen des ZNS dar. Hierbei sind sie in der Lage, als adaptive Immunabwehr MHC-II-Moleküle zu exprimieren und damit Antigene zu präsentieren und T-Zellen zu aktivieren (Schwartz et al. 2006). Auf der anderen Seite vermögen sie sich im Sinne einer angeborenen Immunabwehr in phagozytierende Zellen zu wandeln. Dazu ändern Mikroglia auf einen pathologischen Reiz hin ihr ruhendes Profil in einen aktivierten Zustand. Morphologisch sind sie nun gekennzeichnet durch einen abgerundeten Zellleib mit vielen Vesikeln (Ling EA 1976). Der Aktivierungszustand und auch der Phänotyp hängen jedoch stark vom auslösenden Stimulus ab. So gibt es eine 
Vielzahl von Aktivierungszuständen, die spezifisch auf den jeweiligen Reiz hin ausgelöst sind (Schwartz et al. 2006).

Bei Aktivierung der Mikroglia durch einen pathologischen Stimulus beginnen sie zu proliferieren. Zusätzlich zu der intrinsischen Proliferation erfolgt die Erneuerung der Population durch Rekrutierung von monozytären Zellen. Solche Zellen finden sich beispielsweise perivaskulär, im Raum zwischen dem Endothel und den Fußfortsätzen der Gliazellschicht, die um das Gefäß herum angeordnet ist (Hanisch und Kettenmann 2007). Neben der Mikroglia existieren also ebenfalls Makrophagen im ZNS. Als wichtigste wären hier die perivaskulären, die Plexus-choroideus-assoziierten sowie die Menigealmakrophagen zu nennen (Bechmann et al. 2006). Einmal aktivierte Mikroglia lässt sich morphologisch kaum von infiltrierenden Monozyten unterscheiden und zudem nehmen Monozyten nach einiger Zeit im Gehirn eine Morphologie ein, die der ramifizierter Mikroglia gleicht (Priller et al. 2001, Bechmann 2005). Es konnte gezeigt werden, dass auf einen pathologischen Reiz hin große Mengen von monozytären Zellen in das ZNS einwandern können (Hanisch und Kettenmann 2007).

Die Mikrogliazellen befinden sich damit in einem dualen Kontinuum zwischen den Aufgaben als Immunzellen und Gliazellen des Gehirns. Dabei ist auch zu berücksichtigen, dass beispielsweise eine überschießende Immunreaktion der Mikrogliazellen Schaden anrichten und neurodestruktiv wirken kann. Voll aktivierte Mikroglia ist neurotoxisch. Sie sezernieren reaktive Sauerstoffspezies, NO oder TNF- $\alpha$ und können damit potenziell Neurone, Oligodendrozyten oder extrazelluläre Matrix degradieren (Hanisch und Kettenmann 2007). Der Aktivierungszustand der Mikrogliazellen hängt von einem feinen Zusammenspiel aktivierender und inhibierender Botenstoffe ab. Geraten diese steuernden Signale aus ihrem Gleichwicht, kann es zu überaktivierter Mikroglia kommen, die eine Schädigung des empfindlichen Hirngewebes nach sich zieht (Nakamura 2002). Obendrein lassen neuere Untersuchungen vermuten, dass gerade von den Mikrogliazellen sezernierte Zytokine, wie das $\mathrm{TNF} \alpha$, ursächlich für die Fragmentation von tight-junctions und damit der Zerstörung der Blut-Hirnschranke sind, wodurch Moleküle und Leukozyten aus dem Blut frei in das Hirn penetrieren können (Gloor et al. 2001, Poritz et al. 2004, Wang et al. 2005, Bechmann et al. 2006). So erscheint es in diesem Zusammenhang nicht verwunderlich, dass die Mikrogliazellen eine entscheidende Rolle in neurodegenerativen Erkrankungen spielen, wie beispielsweise bei dem Morbus Parkinson, in der Alzheimer-Erkrankung, im Rahmen einer zerebralen Ischämie oder etwa bei der Multiplen Sklerose (Nakamura 2002). 


\subsection{Existiert Tumor-assoziierte Mikroglia?}

Wie bereits im Kapitel 1.2. erwähnt, wurden schon Ende des 19. Jhdts. Makrophagen beschrieben, die sich in der Nähe von Tumorzellen ansammeln (Balkwill und Mantovani 2001). Seit dieser Zeit hat eine Vielzahl von Untersuchungen dazu beigetragen, dass man heute im Allgemeinen von Tumor-assoziierten Makrophagen (TAM) spricht. Doch gilt dies ebenfalls für das ortsständige Äquivalent im ZNS, für die Mikroglia? Kann man hier eventuell gleichermaßen von Tumor-assoziierter Mikroglia sprechen?

Man weiß heute, dass beispielsweise in hirneigenen Tumoren, wie dem Glioblastom, ein großer Teil des tumorösen Gewebes, nämlich ca. 30\%, aus Mikrogliazellen besteht (Markovic et al. 2005, Sliwa et al. 2006). In Astrozytomen WHO-Grad II-IV scheint der Grad und die Malignität des Tumors in einem proportionalen Zusammenhang mit der Infiltrationsdichte an Mikroglia zu stehen (Roggendorf et al. 1996). Für das Glioblastom wurde gezeigt, dass die Mikrogliazellen auf die Glioblastomzellen zuwandern und insbesondere in dem Grenzbereich zwischen Tumor und dem gesunden Gewebe akkumulieren (Hanisch und Kettenmann 2007). Es wurde beobachtet, dass die Mikroglia in der Nähe der Tumorzellen einen runden, aktivierten Phänotyp einnehmen (Bettinger et al. 2002). Vor allem ist in diesem Kontext interessant, dass Mikroglia die Migration und Invasivität von Gliobalstomzellen verstärken (Sliwa et al. 2007). Für Glioblastomzellen ist bekannt, dass sie Mikroglia aktivieren (Markovic et al. 2005). Die Autoren konnten zeigen, dass Mikroglia unter dem Einfluss von Glioblastomzellen, extrazelluläre Matrix degradieren und so die Invasion der Tumorzellen vorbereiten und fördern. Zudem wurde von einigen weiteren Autoren beschrieben, dass Mikroglia in ihrer Funktion als Abwehrzellen des Gehirns geschwächt werden, sie sezernieren Zytokine, Botenstoffe und Wachstumsfaktoren. Dies trägt dazu bei, dass die Tumorzellen erfolgreich die Immunabwehr des Gehirns hintergehen können (Bettinger et al. 2002, Färber et al. 2008, Markovic et al. 2005, Sliwa et al. 2007, Watters et al. 2005, Wesolowska et al. 2008). Allerdings muss man hinzufügen, dass sich gerade bei dem Glioblastom die Datenlage ambivalent präsentiert. Es wurde hier für die Mikroglia auch Phagozytose und die Induktion von Apoptose bei den Glioblastomzellen als Hinweis auf eine zytotoxische Funktion beobachtet (Galarneau et al. 2007; Villeneuve et al. 2005). 
Die zitierten Fakten, die eine möglicherweise entscheidende Rolle der Mikroglia bei der Tumorprogression belegen, stammen ausschließlich von hirneigenen Tumoren, wie dem Glioblastom als Beispiel für einen hochmalignen Tumor hirneigenen Ursprungs. Den Hauptteil der Neoplasien im Gehirn bilden jedoch zerebrale Metastasen von Tumoren epithelialen Ursprungs. Meistens stammen die Tochtergeschwülste von Lungen- oder Brustkrebstumoren ab. Hirnmetastasen treten bei ca. $20 \%-30 \%$ der Patienten mit systemischer Metastasierung auf (Posner 1992). Dabei nimmt die Häufigkeit, mit der Hirnmetastasen auftreten, zu. Dies liegt vor allem an einer besseren Früherkennung und Primärtherapie, wodurch sich das Überleben der Patienten verlängert und es damit in wachsender Zahl zur Bildung von Metastasen kommt (Barnholtz-Sloan et al. 2004). Insbesondere beim Hormonrezeptor-negativen und cerbB2-negativen Mamma-Karzinom ist eine wachsende Inzidenz von Hirnmetastasen zu verzeichnen (Pestalozzi 2009). Im Gegensatz zum gehäuften Auftreten von Hirnmetastasen hinken die Fortschritte in der Therapie derselben hinterher. Bis heute existieren wenige Hinweise über die Rolle der Mikroglia in Hirnmetastasen epithelialer Primärtumore, wie zum Beispiel dem Mamma-Karzinom. Übt Mikroglia auf Tumore epithelialer Herkunft einen prometastatischen Einfluss aus?

Die wissenschaftliche Untersuchung der Mikroglia bei der zerebralen Metastasierung gestaltet sich schwierig. Es existieren nur wenige Modelle, die eine annähernd wirklichkeitsgetreue Beobachtung der Interaktionen zwischen den Tumorzellen und dem Gehirngewebe erlauben. Weiterhin ist es problematisch, residente Mikroglia von eingewanderten Makrophagen-Populationen zu unterscheiden, da hierfür bislang kein etablierter Marker vorliegt. Lösungsansätze hierzu lieferte beispielsweise Watters mit der Messung von CD45 low versus CD45 high exprimierenden CD11b/c-positiven Zellen (Watters et al. 2005). Diese und andere Versuche lassen jedoch noch Zweifel aufkommen, ob eine genaue Identifizierung und auch Separierung der Subpopulationen von Mikroglia und Makrophagen möglich sind. Darüber hinaus erlauben es Zellkulturmodelle beispielsweise nicht, die Tumorzellen, die Mikroglia und das Tumorstroma, in ihrer Dreidimensionalität zu betrachten. Zur Aufklärung der Vorgänge zerebraler Metastasierung ist aber eine hochauflösende 3-D-Betrachtung der Tumorinvasion erforderlich. Hier setzt die vorliegende Arbeit an, wobei die nachfolgend näher beschriebene Zielsetzung verfolgt wird. 


\subsection{Ziel der Arbeit}

Übergeordnetes Ziel der Arbeit ist es, einen Beitrag zum Verständnis zerebraler Metastasierung von Mamma-Karzinomen zu leisten, wobei insbesondere der Einfluss der Mikroglia als ortsständige Makrophagen des Gehirns auf diesen Prozess im Fokus der Betrachtung steht. Hierzu sollen die Wechselbeziehungen zwischen Tumorzellen, Mikroglia und dem Tumorstroma beobachtbar gemacht werden. Um dieses Primärziel zu verwirklichen, sollen folgende Fragen geklärt werden:

Frage 1: Ist es möglich, ein ex-vivo-Zellkulturmodell zu etablieren, welches für Mikroglia annähernd physiologische Verhältnisse schafft?

Es gilt, eine Methode zu identifizieren und zu etablieren, die es gestattet, Gehirngewebe mit vitaler Mikroglia unter in-vitro-Bedingungen zu beobachten. Hierzu wird die Organotypische Hirnschnittkultur als eine potenziell geeignete in-vitro-Methode genauer analysiert und in der sogenannten Interface-Technik für diese Arbeit aufbereitet.

Frage 2: Wie kann aus einem Organotypischen Hirnschnitt und vitalen Tumorzellen eine Ko-Kultur erzeugt werden?

Als innovative Weiterentwicklung der Organotypischen Hirnschnittkultur wird die Entwicklung und Bereitstellung einer bisher noch nicht beschriebenen Ko-Kultur von epithelialen Mamma-Karzinom-Zellen und vitalem Hirngewebe angestrebt. Die KoKultur dient als Invasionsmodell für eine epitheliale Karzinomzelle in das Hirngewebe.

Dabei werden unterschiedliche Methoden evaluiert, die eine Interaktion zwischen Tumorzellen und Mikroglia im direkten Kontakt erlauben.

Frage 3: Mit welchen Instrumenten können die Interaktionen zwischen Tumorzellen und Mikroglia beobachtet werden und welche Erkenntnisse können hinsichtlich der Tumorinvasion daraus abgeleitet werden?

Die zuvor aufbereitete Organotypische Hirnschnittkultur wird als Ko-Kultur aus Mamma-Karzinom-Zellen und vitalem Hirngewebe beispielhaft angewandt. Konfokale Lasermikroskopie sowie die Time-Lapse-Mikroskopie sollen auf ihre Eignung hin überprüft werden, die zeitlichen Veränderungen in dieser Ko-Kultur dreidimensional zu beobachten. Die Beobachtungen werden detailliert ausgewertet und zu neuen Thesen zur Tumorinvasion zusammengefasst. Schließlich werden weitere, über den 
Gegenstand dieser Arbeit hinausgehende Anwendungsmöglichkeiten der neu entwickelten Methode dargelegt und ihr Potenzial für weitere wissenschaftliche Untersuchungen diskutiert. 


\section{Material und Methoden}

\subsection{Material}

Nachfolgend sind die Materialien aufgelistet, die für die jeweiligen Arbeitsschritte benutzt wurden

\subsubsection{Zellkultur und Hirnschnittkultur}

Actrapid

Agar

Bovine Serum Albumin (BSA)

Dulbecco's Modified Eagle Medium (DMEM)

Extracellular Matrix (ECM) Gel

Fetal Calf Serum (FCS)

Glukose 40\%

Hank's Buffered Sodium Solution (HBSS)

L-Ascorbinsäure, $10 \mathrm{mg} / \mathrm{ml}$

L-Glutamin 200mM

Minimal Essential Medium (MEM) mit

Earle's Salzen

Natriumbikarbonat $(7,5 \%)$

Normal Goat Serum (NGS)

Normal Horse Serum (NHS), hitzeinaktiviert

Paraformaldehyd, 4\%

Phosphate Buffered Saline (PBS)

Penicillin/Streptomycin

Roswell Park Memorial Institute (RPMI) 1640

Sekundenkleber

Triton X

Trypsin Ethylenediaminetetraacetic Acid (EDTA)
Novo Nordisk A/S,

D-Bagsvaerd

Sigma-Aldrich, Steinheim

Biomol, Hamburg

Biochrom, Berlin

Sigma-Aldrich, Steinheim

Sigma-Aldrich, Steinheim

B-Braun, Melsungen

Invitrogen, Karlsruhe

Merck, Darmstadt

Invitrogen, Karlsruhe

Hepes Invitrogen,

Karlsruhe

Gibco, Invitrogen, Karlsruhe

Sigma-Aldrich, Steinheim

Invitrogen, Karlsruhe

Merck, Darmstadt

PAN Biotech, Aidenbach

Life Technologies, Wiesbaden

Sigma-Aldrich, Steinheim

UHU, Bühl

Sigma-Aldrich, Steinheim

Biochrom, Berlin 


\subsubsection{Zellen}

Die in dieser Arbeit verwendeten Zelllinien sind in Tabelle 2.1 aufgeführt. Die Zellen wurden bei $37^{\circ} \mathrm{C}$ und $95 \%$ Luftfeuchtigkeit mit $5 \% \mathrm{CO}_{2}$ inkubiert.

\begin{tabular}{|c|c|c|c|}
\hline Zelllinie & Spezies & Zelltyp & Referenz \\
\hline MCF-7 & Homo Sapiens (human) & $\begin{array}{l}\text { Epitheliale Mamma- } \\
\text { Adenokarzinom-Zelle }\end{array}$ & $\begin{array}{l}\text { HTB-22, ATTC, } \\
\text { Rockville, Maryland, } \\
\text { USA }\end{array}$ \\
\hline L428 & $\begin{array}{l}\text { Homo Sapiens } \\
\text { (human) }\end{array}$ & $\begin{array}{l}\text { Hodgkin-Lymphom- } \\
\text { Zelle }\end{array}$ & $\begin{array}{l}\text { Freundlicherweise zur } \\
\text { Verfügung gestellt von } \\
\text { Kube, D. }\end{array}$ \\
\hline
\end{tabular}

Tabelle 2.1 Verwendete Zellinien

\subsubsection{Stabil transfizierte Zellen}

MCF-7e GFP:

pEGFP-N2 4.7kb GenBank Accession \#: U57608, BD-Falcon, Heidelberg

MCF-7 Turbo GFP:

Mammalian expression vector pturboGFP-C, Evrogen, Moskau, Russland

MCF-7 Turbo 635:

Mammalian expression vector pturboFP635-C, Evrogen, Moskau, Russland

L428:

pEGFP, Clontech Laboratories, Mountain View, California, USA

\subsubsection{Verbrauchsmaterialien}

Einmal-Pasteurpipetten, $5 \mathrm{ml}$

Einmal-Pasteurpipetten, $1 \mathrm{ml}$

Einmal-Skalpell Aesculap,

Glaspasteurpipetten (230mm)

Membraneinsätze, 0,4 $\mu \mathrm{m}$ Porengröße

Operationsbesteck

Rasierklingen

Rundfilter, $55 \mathrm{~mm}$

Sechs-Loch-Platten
VWR, Darmstadt

Lab Logistics, Meckenheim

Tuttlingen

WU, Mainz

BD Falcon, Heidelberg

Omnilap, Göttingen

Wilkinson, Solingen

Macherey-Nagel, Düren

Nunc, Wiesbaden 
Zellkulturflaschen

Nunc, Wiesbaden

Wenn nicht anders benannt, wurden alle weiteren Kunststoff-Verbrauchsmaterialien über das Unternehmen Sarstedt, Nümbrecht, bezogen.

\subsubsection{Verwendete Geräte}

Binocular

$\mathrm{CO}_{2}$-Begaser

Dampfsterilisator, Varioklav

Incubator BL-Leica

Kamera DFC 350 FX

Laser-Scanning-Mikroskop LSM 510

Life-Imagine-Mikroskop Leica DMI 6000B

Magnetrührer mit Heizplatte

Mikroskope

Pipettus

Sterilwerkbank, MSC-Advantage

Virbratom VT 1000S

Vortex

Wasserbad

Zellkultur-Inkubator

Zentrifuge Centrifuge $5415 \mathrm{C}$

Zentrifuge Multifuge $3 \mathrm{~L}-\mathrm{R}$
Carl Zeiss, Göttingen

Leica, Wetzlar

Thermo Fischer Scientific,

Schwerte

Leica, Wetzlar

Leica, Wetzlar

Carl Zeiss, Göttingen

Leica, Wetzlar

Ikamag Reo, Staufen

Carl Zeiss, Göttingen

Integra Bioscience, Fernwald

Thermo Scientific, Langen-

Selbold

Leica, Wetzlar

Schütt, Göttingen

GFL, Großburgwedel

Sanyo, Etten Leur, Niederlande

Eppendorf, Hamburg

Heraeus Instruments, Hanau

\subsubsection{Verwendete Tiere}

Mäuse NMRI, p5-p7

Bezug über Charles River, Sulzfeld

Die Aufzucht der Tiere fand für die NMRI-Mäuse in der Zentralen-Tierstall-Einrichtung (ZTE) der Universitätsmedizin Göttingen statt. Die Tötungsanzeige der Tiere erfolgte für die NMRI-Mäuse über die Arbeitsgruppe von Prof. Dr. rer. nat. Uwe Hanisch.

\subsubsection{Antikörper}


$\begin{array}{ll}\text { 4', 6-Diamidin-2-Phenylindol (DAPI) } & \text { gen, Karlsruhe } \\ \text { Sigma-Aldrich, Steinheim }\end{array}$

\subsubsection{Medium zum Eindeckeln}

Tropfen Fluorescent Mounting Medium Dako, Californien, USA

\subsubsection{Materialien für die Agarherstellung}

Agar

Sigma-Aldrich, Steinheim

Natriumchlorid

Roth, Karlsruhe

Kaliumchlorid

Merck, Darmstadt

Natriumhydrogenphosphat-Monohydrat

Merck, Darmstadt

Magnesiumsulfat-Heptahydrat

Merck, Darmstadt

Natriumhydrogencarbonat

Merck, Darmstadt

Glukose

Sigma-Aldrich, Steinheim

Calciumchlorid-Dihydrat

Merck, Darmstadt

\subsection{Methoden}

\subsubsection{Kultivierung der Zellen}

Die verwendeten Zelllinien MCF-7 und L428 werden unter den gleichen Bedingungen bei $37^{\circ} \mathrm{C}, 90 \%$ Luftfeuchtigkeit und $5 \% \mathrm{CO}_{2}$ in Flaschen mit $75 \mathrm{~cm}^{2}$ Grundfläche in Kultur gehalten. Für die Zelllinien MCF-7 und L428 wird als Zellkulturmedium RPMI 1640 , versetzt mit $10 \%$ fetalem Kälberserum (FCS), hitzeinaktiviert (30 min bei $56^{\circ} \mathrm{C}$ ), verwendet. Die epitheliale MCF-7 Zelllinie besitzt die Eigenschaft, adhärent auf dem Boden eines Zellkulturgefäßes zu wachsen. Aus diesem Grund werden die Zellen vor Entnahme zunächst mit PBS gespült, um die Mediumreste zu entfernen und alsdann mit einer Trypsin-EDTA-Lösung (0,05\% Trypsin, 0,02\% EDTA ( $w / v$ in PBS)) behandelt, um sie von der Zellkulturflasche abzulösen. Anschließend können Sie erneut in dem entsprechenden Kulturmedium aufgenommen werden. Die zweiwertigen Ionen im Medium inaktivieren dabei die Wirkung des Trypsins. Je nach der gewünschten Zellmenge werden die Zellen in einer Konzentration von 1-2x $10^{5}$ Zellen/ml erneut in $10 \mathrm{ml}$ Medium ausgesät. Die mesenchymale Zelllinie L428 ist im Gegensatz zu der MCF-7 keine adhärente Zelle. Zum Splitten wird hier das Medium mit den darin enthaltenen frei flottierenden Zellen abgesaugt und bei $850 \mathrm{rpm}$ für 5 Minuten abzentrifugiert. Nach Verwerfen des Überstandes kann der so entstandene 
Zellrasen am Boden des Eppendorf-Cups, welches zum Zentrifugieren verwendet wird, resuspendiert und ähnlich der Zelllinie MCF-7 in einer Konzentration von 1-2 × 10 erneut in $10 \mathrm{ml}$ Medium ausgesät werden. Alle drei Tage erfolgt eine Erneuerung des Nährmediums. Bei Erreichen eines konfluenten Zellrasens können die Zelllinie MCF-7 erneut abtrypsiniert bzw die Zelllinie L 428 äquivalent abzentrifugiert und in einem Verhältnis von 1:2 - 1:4 gesplittet werden.

\subsubsection{Auszählung der Zellen}

Die Zellzahl wird mit Hilfe der Neubauer-Improved-Zählkammer bestimmt. Die Zellmenge wird dabei in einem definierten Volumen $\left(0,4 \mathrm{~mm}^{3}\right)$ ermittelt. Anschließend kann die so bestimmte Zellmenge in eine Konzentration (Zellzahl/ml) umgerechnet werden.

\subsubsection{Die Methode der Organotypischen Hirnschnittkultur}

Um zu untersuchen, ob auch Mikroglia eine Tumorausbreitung fördern können, ist es sinnvoll, eine Methode zu verwenden, die die Vorgänge im Gehirn im Verlauf der Metastasierung quasi live aufzeigt. In reinen Zellkulturen verhalten sich Mikrogliazellen anders als in ihrem physiologischem Milieu (Streit et al. 1999). Um abzubilden, was zwischen Tumorzellen und Mikroglia geschieht, braucht es einen Versuchsansatz, der annähernd diese physiologischen Verhältnisse gewährleistet. Dies ist insbesondere deswegen notwendig, da die Antwort der Mikroglia auf maligne Zellen auch von ihrer Kommunikation über komplexe Signalwege mit anderen Zelltypen des Hirngewebes abhängt.

Bei der Organotypischen Hirnschnittkultur handelt es sich um eine ex-vivo-Methode, die für vitales Hirngewebe in vitro näherungsweise die gleichen Rahmenbedingungen wie im lebenden Organismus schafft. Sie hat sich in diesem Zusammenhang als gutes Modell etabliert. Dabei weisen die in Kultur gehaltenen Organschnitte eine Morphologie und Ausdifferenzierung der Hirnzellen auf, die sehr stark denen in situ gleicht. So eignet sich die Organotypische Hirnschnittkultur beispielsweise ideal dazu, neurodegenerative Erkrankungen zu untersuchen, da die Neuronenkreisläufe intakt bleiben. Beispielsweise zeigen die dendritischen Fortsätze der Pyramidalneurone einen Aufbau und eine Komplexität, wie sie auch in vivo beobachtet werden können (Stoppini et al., 1991). Zur Herstellung und Durchführung einer Organotypischen Hirnschnittkultur haben sich bis heute verschiedene Methoden der Kultivierung 
bewährt. In dem Review von 1997 stellten Gähwiler et al. die drei Hauptvertreter dieser Kulturmöglichkeiten mit ihren Vor- und Nachteilen gegenüber. Die drei wesentlichen Methoden bestehen aus der Roller-Tube-Technik, außerdem die stationäre, in ein Kollagen-Gel eingebettete Kultur sowie der Interface-Methode.

Alle drei Kulturmethoden haben gemeinsam, dass sie die hirneigene Zytoarchitektur bewahren und eine exzellente Ausdifferenzierung der Zellen erlauben. Bei allen drei Techniken kommt es im Verlauf der Kultur zu einem Abflachen der Schnitte.

Während die Roller-Tube-Technik beispielsweise den Vorteil optimaler, optischer Bedingungen bietet, ist die Interface-Technik vor allem zur Darstellung dreidimensionaler Strukturen und für morphologische Studien geeignet.

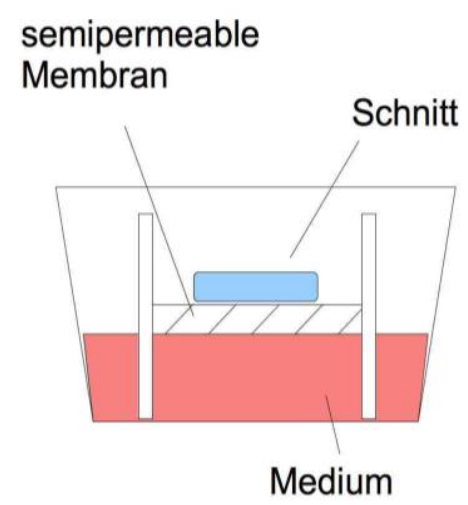

Abbildung 2.1 Interface Technik (nach Gähwiler et al., 1997) Der Organotypische Hirnschnitt befindet sich auf einer semipermeablen Membran. Die Oxygenierung erfolgt von oben mit Sauerstoff und der Nährstoffaustausch durch das Medium von unten.

Im Rahmen dieser Arbeit wurde die Interface Technik eingesetzt. Der Hirnschnitt kann in der Kultur zu jedem Arbeitsschritt beobachtet werden, da das Gewebe zu keinem Zeitpunkt von Einbettmaterial umgeben wird (Gähwiler et al., 1997). Da die Membran durchsichtig ist, kann das Gewebe in regelmäßigen Abständen mit dem Auflichtmikroskop in der Kultur kontrolliert werden (Stoppini et al., 1991). Des Weiteren ist der Schnitt auf der Membran leicht zugänglich. Dies ist für die vorliegende Fragestellung evident, da im Folgenden unter der laufenden Kultur Tumorzellen neben dem Hirnschnitt platziert werden. Zuletzt zeichnet sich die Methode durch ihre relativ einfache Handhabung aus (Stoppini et al., 1991) 


\subsubsection{Herstellung des Agars}

Um das Hirngewebe während des Schneidevorganges im Vibratom zu stabilisieren, wird das Gehirn mit Agarblöcken abgestützt. Zur Erzeugung eines sterilen, festen Agars wird zunächst eine ACSF-Lösung angesetzt. Für $200 \mathrm{ml}$ dieser ACSF-Lösung werden folgende Zutaten nacheinander in $200 \mathrm{ml}$ Aqua dest. gegeben: $1,45 \mathrm{~g}$ Natriumchlorid, $0,0746 \mathrm{~g}$ Kaliumchlorid, 0,0345 g NatriumdihydrogenphosphatMonohydrat, 0,0986 g Magnesiumsulfat-Heptahydrat, 0,4368 g Natriumhydrogencarbonat, 0,36 g Glukose und zuletzt 0,0588 g Calciumchlorid-Dihydrat. Die beigemengten Substanzen werden auf einem Magnetrührer eingerührt. In die so hergestellte 200 -mlLösung werden $10 \mathrm{~g}$ Agar-Agar (5\%) gelöst und unter Rühren auf dem Magnetrührer mit Heizplatte zum Kochen gebracht. Wenn eine gelartige, homogene Substanz entstanden ist, wird die Masse aus Agar-Agar und ACSF-Lösung autoklaviert. Anschließend wird das noch heiße Gemisch unter der Sterilwerkbank in Petrischalen gegossen. Nach dem Abkühlen und Festwerden der Agarmasse werden die Petrischalen mit Parafilm verschlossen und im Kühlschrank bis zum Gebrauch aufbewahrt.

\subsubsection{Herstellung des Präparationsmediums}

Präparationsmedium Maus:

Für 100,125 ml Präparationsmedium werden folgende Substanzen verwendet:

$97 \mathrm{ml}$ MEM

$1 \mathrm{ml}$ Penicillin/Streptomycin

$1 \mathrm{ml}$ Glutamin

$1,125 \mathrm{ml}$ Glukose (40\%).

Präparationsmedium Ratte:

$100 \mathrm{ml}$ des Präparationsmediums der Ratte enthalten:

$99 \mathrm{ml}$ MEM

$1 \mathrm{ml}$ Glutamin.

\subsubsection{Herstellung des Inkubationsmediums}

\section{Inkubationsmedium Maus:}

100,125 ml Nährlösung setzen sich zusammen aus:

$47 \mathrm{ml}$ MEM

$25 \mathrm{ml} \mathrm{HBSS}$

$25 \mathrm{ml} \mathrm{NHS}$ 
$1 \mathrm{ml}$ Penicillin/Streptomycin

$1 \mathrm{ml}$ Glutamin

$1,125 \mathrm{ml}$ Glukose (40\%).

Inkubationsmedium Ratte:

100,0275 ml Inkubationsmedium beinhalten:

45,7 ml MEM

$25 \mathrm{ml} \mathrm{HBSS}$

$0,08 \mathrm{ml}$ Vitamin C

$1 \mathrm{ml}$ Penicillin/Streptomycin

$2 \mathrm{ml}$ Glutamin

0,6 ml Glukose (40\%)

$0,58 \mathrm{ml}$ Natriumbicarbonat $(7,5 \%)$

$0,0675 \mathrm{ml}$ Actrapid

$25 \mathrm{ml} \mathrm{NHS}$.

\subsubsection{Herstellung der Organotypischen Hirnschnitte}

Um die Interface-Technik hin zu einer Ko-Kultur mit Tumorzellen zu modifizieren, erfolgte eine Orientierung an den vorher beschriebenen Protokollen von Markovic et al. (2005) sowie von Kohl et al. (2003) und Dehghani et al. (2004). In Anlehnung an die dort ursprünglich für Ratten beschriebenen Protokolle wurde die Organotypische Hirnschnittkultur zunächst folgendermaßen durchgeführt und - wie unter Resultate geschildert - später Schritt für Schritt an die speziellen Gegebenheiten angepasst:

Für die Herstellung der Organotypischen Hirnschnitte werden Mäuse im Alter von 5-7 Tagen verwendet. Nach dem Dekapitieren der Tiere wird das Gehirn entnommen. Hierzu wird die Kalotte mit einer Schere eröffnet. Der Zugangsweg erfolgt über das Foramen magnum durch das Kleinhirn in der Mittellinie bis zum Bulbus olfactorius. Die Schädelkalotte wird vorsichtig mit einer kleinen chirurgischen Pinzette nach hinten gezogen, so dass darunter das Gehirn freigelegt wird. Das Kleinhirn sowie etwa ein Drittel des Vorderhirns werden mit dem Skalpell abgetrennt. Anschließend wird das mittlere Hirnstück in Minimal Essential Medium überführt, welches 1\% Glutamin enthält und auf $4^{\circ} \mathrm{C}$ temperiert ist. Das Gehirn wird auf einem Träger mit einem Cyanoacrylat Kleber befestigt, mit Agarblöcken abgestützt und stabilisiert und kann schließlich mit einem Vibratom in $350 \mu m$ dicke Koronarschnitte geschnitten werden. Die Hirnschnitte werden auf einem $0.4 \mu \mathrm{m}$ großen Millipore-Membraneinsatz transferiert und in eine Sechs-Loch-Platte eingesetzt. Die Sechs-Loch-Platte enthält pro Loch $1 \mathrm{ml}$ 
Kulturmedium. Die Zusammensetzung dieses Inkubationsmediums ist unter Punkt 2.2.2.1.3 beschrieben. Die Hirnschnitte werden im Zellkultur-Inkubator bei $37^{\circ} \mathrm{C}, 5 \%$ $\mathrm{CO}_{2}$ und $90 \%$ Luftfeuchtigkeit in Kultur gehalten. Das Kulturmedium wird dabei alle zwei Tage gewechselt.

\subsubsection{Fixierung der Hirnschnitte}

Nach 5 Tagen in Kultur werden die Hirnschnitte fixiert. Nach Entfernen des alten Mediums, wird in den Membraneinsatz sowie in das untere Loch je $1 \mathrm{ml} 4 \%$ PFA eiskalt hinzugegeben. Die Hirnschnitte werden mit dem PFA über Nacht im Kühlraum bei $4^{\circ} \mathrm{C}$ inkubiert.

\subsubsection{Färbung der Schnitte}

Nach Entfernen des 4\%tigen PFAs werden die Schnitte in PBS/Triton (0,2\%) gewaschen. Eine Vorinkubation mit Normal Goat Serum (NGS), 1:20 in PBS/ Triton, 30 min, verhindert unspezifische Bindungen. Um die Mikroglia in dem Hirnschnitt anzufärben, wird der Antikörper Isolectin B4 Alexa Fluor 647 in einer Konzentration von 1:100 in PBS/Triton eingesetzt. Die Schnitte werden über Nacht im Kühlraum mit dem Flurochrom inkubiert. Anschließend erfolgt ein erneuter Waschschritt mit PBS/Triton. Zum Schluss werden die Schnitte mit DAPI in einer Verdünnung von 1:1000 gefärbt. Nach einem letzten Waschschritt werden die Schnitte schließlich von dem Membraneinsatz gelöst und zum Eindeckeln auf einen Objektträger transferiert. Das Eindeckeln erfolgt mit Fluorescent Mounting Medium.

\subsubsection{Auswertung der Schnitte unter dem Konfokalmikroskop}

Mit dem konfokalen Laser-Scanning-Mikroskop LSM 510 kann die indirekte Immunfluoreszenz der gefärbten Hirnschnitte dargestellt werden. Für die Detektion der Fluoreszenzfarbstoffe dient eine Quecksilber-Kurzbogenlampe als Lichtquelle. Die verwendeten Fluorochrome besitzen dabei folgende Extinktionswerte, (vgl. Tab. 2.2):

\begin{tabular}{|l|l|l|}
\hline Fluorochrom & Anregung & Emission \\
\hline EGFP & $488 \mathrm{~nm}$ & $509 \mathrm{~nm}$ \\
\hline DAPI & $358 \mathrm{~nm}$ & $463 \mathrm{~nm}$ \\
\hline Isolectin B4 Alexa 647 & $650 \mathrm{~nm}$ & $668 \mathrm{~nm}$ \\
\hline
\end{tabular}

Tab. 2.2 Extinktionswerte der verwendeten Fluorochrome 
Mit einer im Mikroskop integrierten Kamera können die Schnitte fotografiert werden. Die Bilder wurden mit dem Programm LSM 5 Image Browser bearbeitet und ausgewertet.

\subsubsection{Time-Lapse-Methode}

Um die Hirnschnitte und insbesondere die nachfolgend etablierte Ko-Kultur mit Tumorzellen über einen Zeitraum von 48 Stunden zu beobachten, wurde eine 6-LochPlatte mit den Hirnschnitten und den daneben platzierten Tumorzellen unter das TimeLapse-Mikroskop gesetzt. Die 6-Loch-Platte und das Objektiv des Mikroskops sind bei dem Versuch von einer Inkubationskammer umgeben. Somit ist während des Versuchsvorgangs gewährleistet, dass die Hirnschnitte und die Tumorzellen konstant mit $37^{\circ} \mathrm{C}$ und $5 \% \mathrm{CO}_{2}$, kultiviert werden. Für die $\mathrm{CO}_{2}$-Begasung sorgt eine $\mathrm{CO}_{2^{-}}$ Einrichtung. Mit dem „bright field“ wird das EGFP-Fluoreszenz der Tumorzellen bei einer Exzitations-Wellenlänge von 488nm grün dargestellt. Als Lichtquelle dient eine Leica-Lampe. Mit der Leica-Kamera DFC 350 FX wird von jedem Hirnschnitt in der 6Loch-Platte in einem Abstand von 5', 10' und 15' ein Bild aufgenommen. Diese Fotos konnten mit der Software „LAS AF Lite" und mit der Software „Video-Spin“ ausgewertet und bearbeitet werden. 


\section{$3 \quad$ Ergebnisse der Methodenentwicklung}

\subsection{Etablierung der Organotypischen Hirnschnittkultur}

Um unter den Kulturbedingungen näherungsweise physiologische Verhältnisse für Mikroglia und Tumorzellen herzustellen, wurde in dieser Arbeit die Interface Technik der Organotypischen Hirnschnittkultur gewählt. Im Hinblick auf Schritt 2, nämlich eine Ko-Kultur zwischen Tumorzellen und den lebenden Hirnschnitt zu schaffen, war es notwendig, einige Änderungen der ursprünglichen Methode, wie sie unter 2.2.2. beschrieben wurde, vorzunehmen:

1. Der Prozess der sterilen Präparation wird für die spätere Kultur mit den Tumorzellen optimiert.

2. Für die Hirnschnittkultur wird nicht mehr nur der hippokampale Anteil des Gehirns, sondern der gesamte Koronarschnitt des Großhirns eingesetzt.

Die zwei Punkte werden in den folgenden Abschnitten genauer erläutert.

\subsubsection{Prozessoptimierung}

Um zu gewährleisten, dass die Hirnschnitte des Tieres ohne Probleme mit den Tumorzellen kultiviert werden können, sollen während der Präparation des Gehirns und während des Schneidevorgangs mit dem Vibratom möglichst sterile Bedingungen herrschen. Dies erfordert verschiedene Maßnahmen. Zum einen werden die einzelnen Arbeitsschritte der Präparation und des Schneidevorgangs unter der geschlossenen Sterilwerkbank durchgeführt. Das Vibratom wird unter der Sterilbank platziert und über Nacht mit UV-Licht bestrahlt. Zum Zweiten werden, soweit möglich, alle verwendeten Geräte, das Präparationsbesteck, die Einsatzwanne des Vibratoms, der Klingenhalter sowie der Teller, auf dem das Gewebe zum Schneiden aufgebracht wird, autoklaviert. Auch der Agar, der zur Abstützung des Gewebes während des Schneidevorgangs Einsatz findet, muss steril sein (siehe unter 2.2.4). 


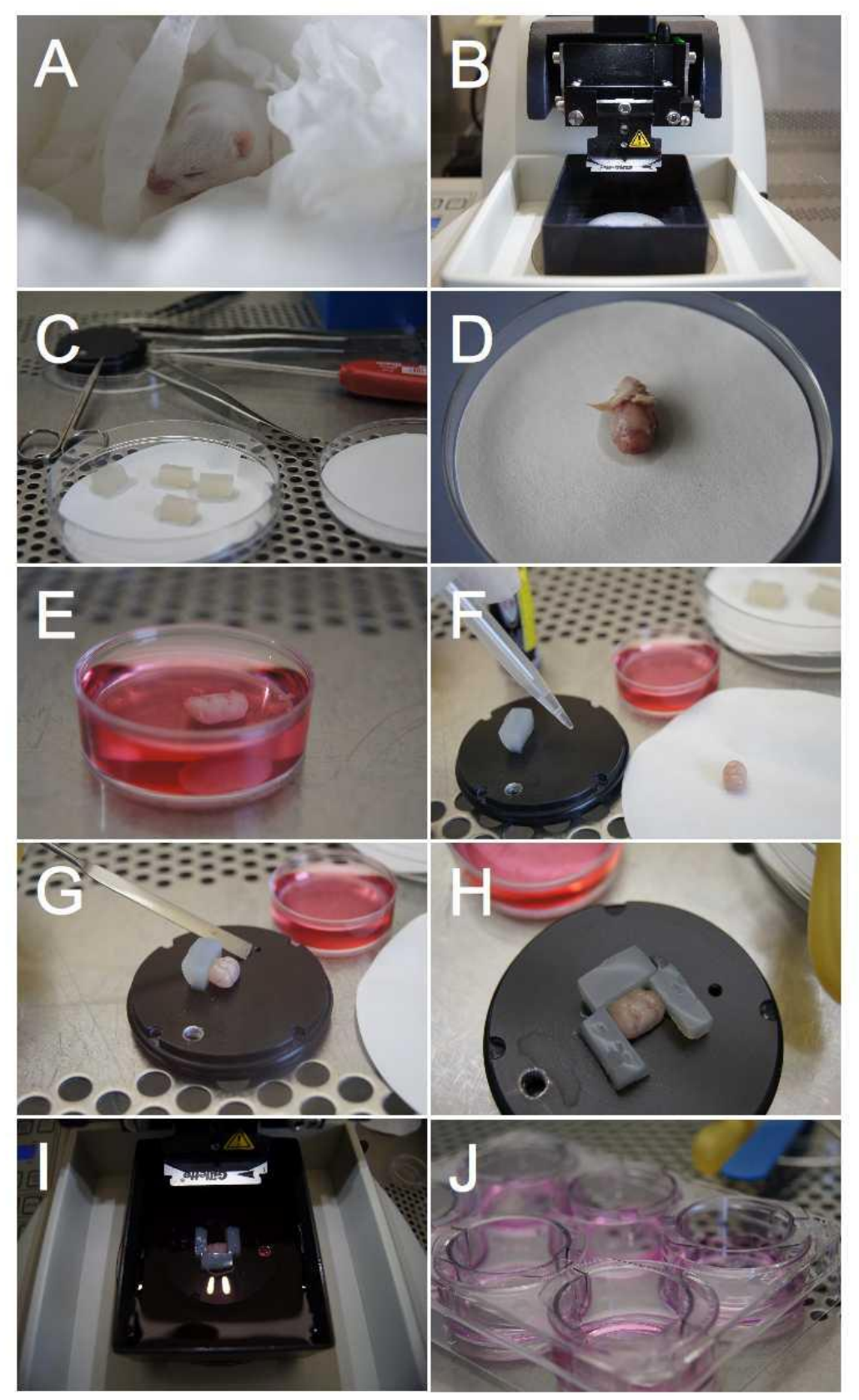

Abbildung 3.1 Ablauf der Präparation A. Für die Gewinnung der organotypischen Hirnschnitte werden 5-7 Tage alte NMRI-Mäuse verwendet. B. Das Vibratom. C. Das Werkzeug. In der Petrischale im Vordergrund sind bereits geschnittene Agarblöcke zu sehen. D. Blick auf die freigelegte Schädelkalotte. E. Das präparierte Gehirn wird aus der Schädelhöhle in eine Petrischale mit eiskaltem Nährmedium überführt. F. Das Gehirn wird auf einem Filterpapier abgetropft und neben dem Vibratomschlitten bereit gelegt. Das Kopfteil aus Agar wird auf dem Schlitten mit Sekundenkleber befestigt. G. Das Gehirn wird schließlich auf den Schlitten transferiert. H. Es wird so vor dem Kopfteil positioniert, dass die Hirnbasis nach oben zeigt und die rostrale Seite dem Agarblock anliegt. Hiernach können die seitlichen Agarblöcke zur Stabilisation angebracht werden. I. Der Schlitten wird in die Wanne des Vibratoms eingebracht. Die Wanne ist mit Kulturmedium gefüllt. J Die gewonnenen Koronarschnitte werden in einer Sechs-Loch-Platte inkubiert. 
Die Hirnschnitte werden in dieser Arbeit aus Mäusen gewonnen. Dabei kommen fünf bis sieben Tage alte Mäuse vom NMRI Stamm zum Einsatz. Demgegenüber werden bei Autoren, die die Organotypische Hirnschnittkultur anwenden, meist Rattengehirne verwendet (Kohl et al. 2003, Dehghani et al. 2004). Die Gehirne der jungen Mäuse sind deutlich kleiner als die der Ratten. Diese veränderten Größenverhältnisse stellen eine Herausforderung dar, da die kleineren Hirne schwieriger zu präparieren sind, ohne dass dabei das Gewebe verletzt wird. Beim Schneidevorgang können ca. 4-6 Schnitte pro Mausgehirn mit dem Vibratom gewonnen werden. Im Vergleich dazu beträgt die Ausbeute eines Rattengehirns in etwa 10-12 Schnitte. Des Weiteren stellen die Mäusegehirne andere Anforderungen an die Kultivierung. Die Zusammensetzung der Inkubations- und Präparations-Medien sind in 2.2.5 und 2.2.6 aufgeführt. Die Zutaten für das Mausmedium sind von der Arbeitsgruppe von PD Dr. med. F. Dehghani übernommen (vgl. Kohl et al. 2003, Dehghani et al. 2004, Kreutz et al. 2009).

Bei der Präparation wird folgender Schritt zusätzlich eingeführt: Die Maus wird unsteril dekapitiert. Um hier bereits die Keimdichte zu reduzieren erfolgt eine Desinfektion des Kopf-Fells mit 70\%igem Alkohol. Das Fell wird mit einer unsterilen Schere in der Mittellinie aufgetrennt und von der Kalotte entfernt (vgl. Abbildung 3.1, D). Der Kopf der Maus kann so dann unter die Sterilbank transferiert werden. Von diesem Zeitpunkt an laufen alle Arbeitsschritte unter den größtmöglichen sterilen Bedingungen ab. Die Kalotte wird mit einer sterilen Schere eröffnet.

Da das Gehirn der Maus sehr viel kleiner als das der Ratte ist, sind einige Hilfsschritte nötig, die eine bessere Handhabung des kleinen Gehirns gewährleisten.

Das Hirnstück wird sehr vorsichtig mit der gebogenen Pinzette in eine kleine, mit eiskaltem Präparationsmedium gefüllte Petrischale überführt (vgl. Abbildung 3.1, E). Mit einer großen Pipettenspitze wird ein Tropfen Sekundenkleber auf den Teller des Vibratoms verteilt und zwar direkt vor dem bereits aufgeklebten Agar-Kopfstück. Der Sekundenkleber kann mit der Spitze des Pipettenaufsatzes aus dem Vorratsbehälter entnommen und auf den Teller aufgebracht werden. Mit diesem Hilfsschritt ist eine genaue Platzierung einer kleinen Menge Kleber für das kleine Gehirn der jungen Maus möglich.

Das Gehirn wird mit der gebogenen Pinzette und dem Spatel aus dem eiskalten Medium gehoben, auf dem Filterpapier abgetropft und schließlich auf die vorbereiteten 
Sekundenkleber gelegt. Dabei wird das Gehirn in der Weise positioniert, dass die basalen Hirnteile nach oben zeigen und das Gehirn mit der rostralen Seite an den Agarblock geklebt wird (vgl. Abbildung 3.1, G). Um die Position des Gehirns zu optimieren, kann der Spatel zu Hilfe genommen werden.

Wenn das Gewebe mittig platziert vor dem Kopfteil liegt, werden zur weiteren Stabilisierung links und rechts des Gehirns die Seitenteile angebracht (vgl. Abbildung 3.1, H). Dazu wird ein schmaler Streifen Sekundenkleber mit der Pipettenspitze längs zu beiden Rändern des Gewebes gezogen und die Agarblöcke eng neben das Gehirn geklebt. Der Teller kann nun mit dem Schraubenzieher in die Wanne des Vibratoms geschraubt werden. Bei dem Einsetzen in die Wanne wird der Teller so eingebracht, dass das Kopfstück des Agars nach vorne zeigt (vgl. Abbildung 3.1, I). Dadurch wird während des Schneidevorgangs eine größere Stabilität erreicht, da das Vibratommesser auf das Kopfteil zuschneidet und es damit verhindert wird, dass Hirngewebe durch die Vibration abbricht und davon schwimmt. Auf eine abgebrochene Spitze einer Pasteurpipette wird ein Gummisauger gestülpt. Mit dem stumpfen Ende kann der gewonnene Hirnschnitt, ohne verletzt zu werden, aus der Vibratomwanne aufgesogen und in eine Petrischale überführt werden. Von hier aus werden die Schnitte auf einen Schlitzmembraneinsatz in der zuvor vorgewärmten 6-Loch-Platte positioniert und schließlich inkubiert (vgl. Abbildung 3.1, J).

\subsubsection{Vom Hippokampus zum Großhirnschnitt}

Bei der hippokampalen Organotypischen Hirnschnittkultur werden nach Gewinnung eines Koronarschnittes der paarige Hippokampus links und rechts vom Hirnschnitt herausgelöst. Dies geschieht unter dem Binocular mit einer runden Skalpellspitze. Die Inzision erfolgt zwischen dem Cornu temporalis des Seitenventrikels, der entorrhinalen Rinde und dem Gyrus parahippocampalis. Dabei entsteht ein etwa 2-3 mm großes Gewebestück (vgl. Abbildung 3.2). Neben diesem herauspräparierten Gewebestück werden die Tumorzellen platziert. Dabei ergibt sich allerdings das Problem, dass der $10 \mu \mathrm{l}$ große Tropfen mit den Tumorzellen ähnlich groß ist, wie das Gewebestück, bzw. der Tumorzelltropfen überragt den hippokampalen Schnitt. In diesem Zusammenhang ist darüber hinaus zu beobachten, dass die Tumorzellen sich bevorzugt in den physiologischen Furchen und Spalten der hippokampalen Struktur sammeln, so zum Beispiel in der Fissur des Cornu temporale des Seitenventrikels. Um die Größenverhältnisse besser anzupassen, wird ein größerer Anteil Hirngewebe mit dem Hippokampus aus dem Hirnschnitt herausgeschält. Um möglichst weiterhin die 
Orientierung an den anatomischen Strukturen einzuhalten, wird entlang der Medianebene des Gehirns geschnitten, so dass der Koronarschnitt in seine zwei Großhirnhälften getrennt wird. Dabei kann festgestellt werden, dass die Tumorzellen sich erneut in prädisponierenden Furchen sammeln, hierbei vor allem entlang der Schnittseite in der Medianebene. Um diesen Effekt zu vermeiden, wird von nun an der gesamte Hirnschnitt verwendet, der rundherum an der Außenseite glatt begrenzt ist und weniger Spalten und Vertiefungen bietet. Des Weiteren liegt bei dem Ganzhirnschnitt der Sulcus des Cornu temporale des Seitenventrikels nicht frei. Die größeren Ganzhirnschnitte sind später schwieriger auf die Insertmembran zu transferieren. Bei dem Umsetzen fällt das Gewebe häufig an den anatomischen Fissuren auseinander. Für die Versuche werden jedoch nur intakte Schnitte verwendet. Aus diesem Grund reduziert sich die Ausbeute pro Maus auf etwa 3-4 verwertbare Schnitte.

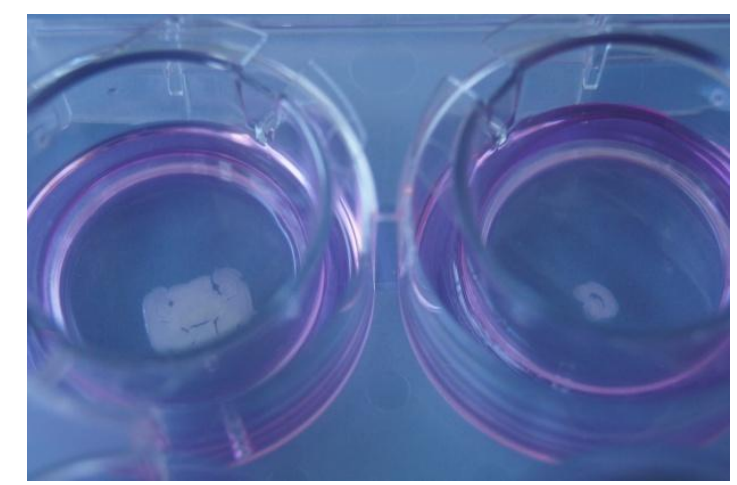

Abbildung 3.2 Größenverhältnis ganzer Koronarschnitt und Hippokampus Auf der linken Seite des Bildes befindet sich in dem Membraneinsatz ein ganzer Koronarschnitt. Auf der rechten Bildhälfte ist der herauspräparierte Hippokampus zu sehen.

\subsection{Entwicklung der Ko-Kultur}

\subsubsection{Die Tumorzellen werden auf dem Schnitt platziert.}

In einem ersten Versuch, ein in-vitro-Ko-Kulturmodell von lebenden Hirngewebe und Tumorzellen zu schaffen, wird eine definierte Menge von Tumorzellen, die stabil mit einem GFP-Konstrukt transfiziert sind, auf den Schnitt pipettiert. Dabei werden die Tumorzellen in einer Konzentration von $1 \times 10^{6}$ Zellen/ml verwendet. Zunächst kann durch Zentrifugation für $5 \mathrm{~min}$ bei $900 \mathrm{rpm}$ ein Zellpellett geschaffen werden. Dieses wird sodann in einer kleinen Menge Medium von $10 \mu \mathrm{l}$ resuspendiert. Diese Zellsuspension wird als Tropfen auf einen $24 \mathrm{~h}$ kultivierten, hippokampalen Hirnschnitt gegeben. Dabei wurde Folgendes beobachtet: Die initiale Konzentration von $1 \times 10^{6}$ 
Zellen/ml war zu hoch gewählt. Unter dem Mikroskop ist die hippokampale Formation unter einer Flut von Tumorzellen kaum auszumachen. Aus diesem Grund wurde mit verschiedenen Zellzahlen gearbeitet, bis schließlich bei einer Konzentration von $1 \times 10^{5}$ Zellen/ml ein ausgewogenes Verhältnis von Tumorzellen und Hirngewebe vorlag. Alle folgenden Experimente wurden anschließend mit dieser Zellmenge durchgeführt.

Wenn die Tumorzellsuspension als Tropfen mittig auf den Hirnschnitt gegeben wird, so bleiben die Zellen dort nicht im Zentrum des Schnittes liegen. Bereits nach $24 \mathrm{~h}$ sind die Tumorzellen zirkulär an die Außenränder des Schnittes gewandert. Sie sammeln sich in Furchen und Vertiefungen und zeigen insgesamt eine recht diffuse Versprengung über den gesamten Hirnschnitt (vgl. Abbildung 3.3).

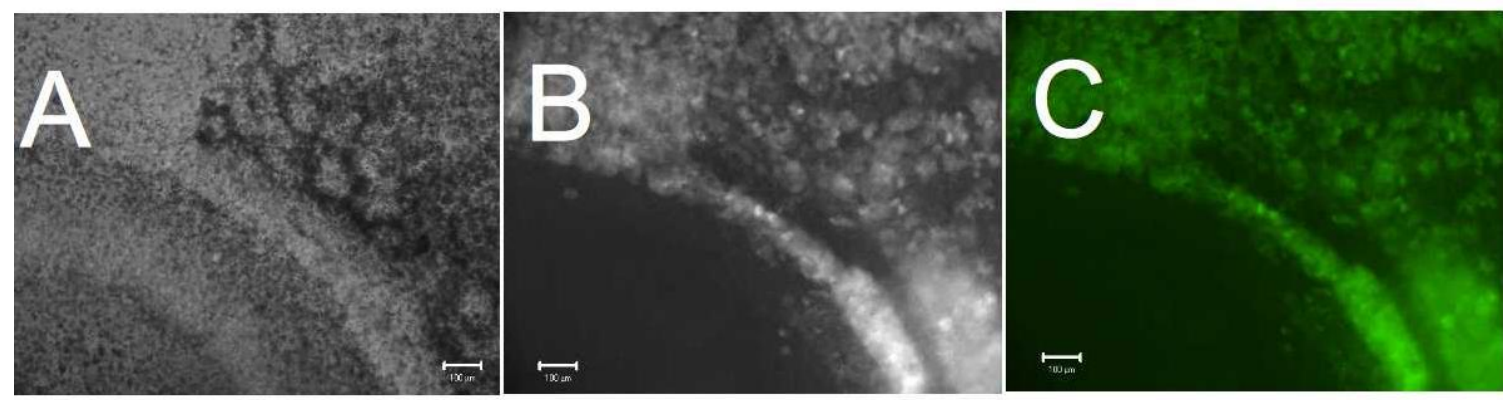

Abbildung 3.3 Erste Versuche, Durchlicht Grün mit GFP transfizierte MCF-7. A-C zeigten jeweils die gleiche Position im hippokampalen Schnitt. A. In der Durchlicht-Mikroskopie zeigt dieses Bild den Außenrand des Ammonhorns des hippokampalen Hirngewebes B. Bild B zeigt die Tumorzellen im Durchlichtmikroskop und C. in Bild C sind die GFP transfizierten Tumorzellen mit dem Fluoreszenzlicht angeregt. Man erkennt, dass die Tumorzellen in den Furchen des Ammonshorn sich sammeln.

Dennoch konnte bei diesen Versuchen folgendes beobachtet werden: Tumorzellen, die auf dem Schnitt verblieben waren oder sich direkt am Schnittrand sammelten, verursachten in ihrer direkten Umgebung eine Aktivierung, Akkumulation und Auswanderung von Mikroglia in den Tumorzellrasen (vgl. Abbildung 3.4). 


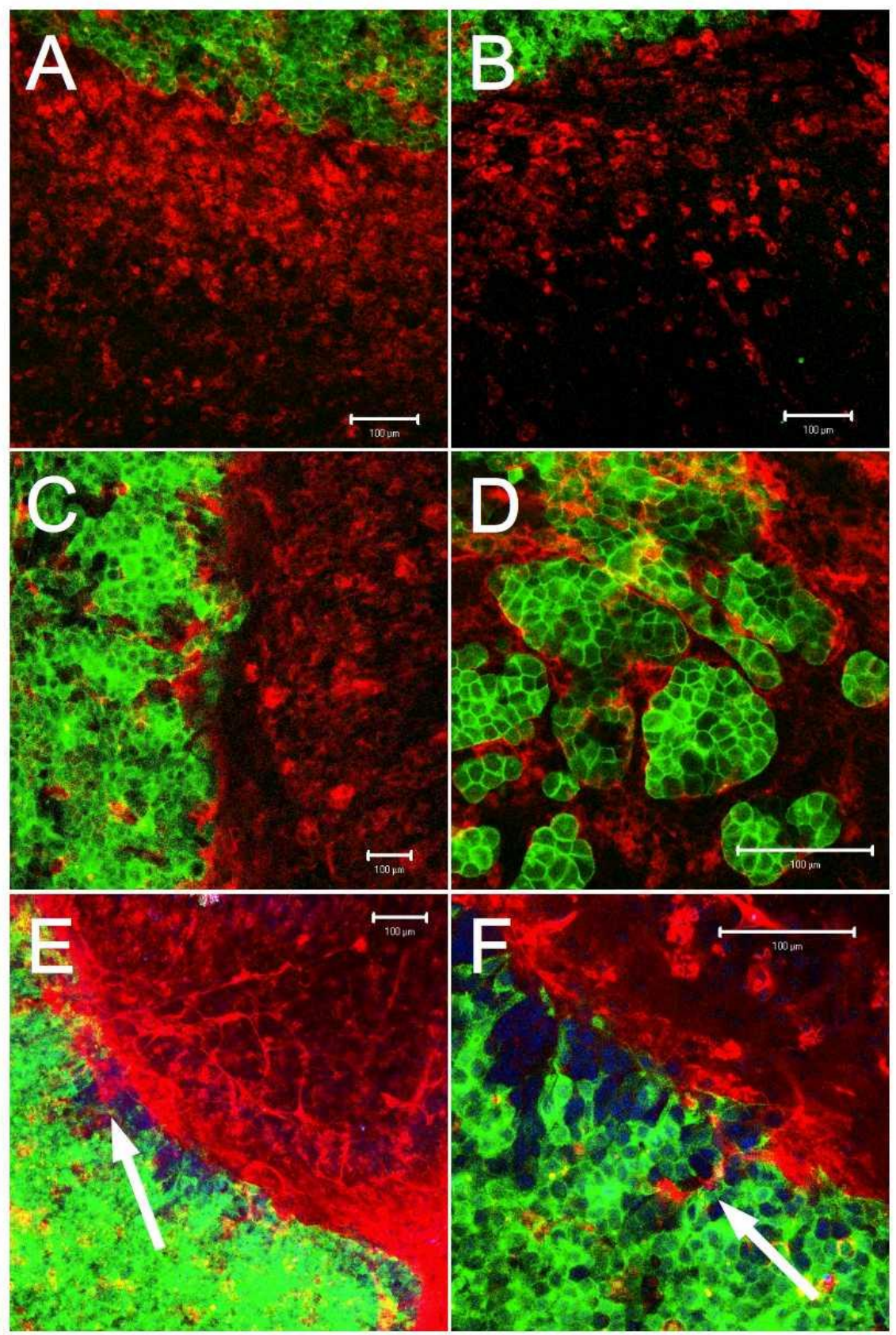

Abbildung 3.4 Erste Versuche mit dem Konfokalmikroskop Rot: mit Isolectin B4 Alexa Fluor 647 angefärbte Mikroglia. Grün: Tumorzellen, mit GFP transfizierte MCF-7. Blau. Kernfärbung mit DAPI. Die Größenmaßstäbe zeigen immer $100 \mu \mathrm{m}$. A. und B. In den ersten Versuchen zeigt sich an der Grenze zu den Tumorzellen, am Rand des Hirnschnittes eine ausgeprägte Reaktion der Mikroglia. C. Die Mikroglia nehmen eine amöboide Morphologie ein. Sie scheinen zu den Tumorzellen hin zu akkumulieren. D. Ausschnitt aus der Mitte des Hirnschnittes, wo sich Nester von Tumorzellen finden, die in den Hirnschnitt eingewandert sind. Die Tumorzellen sind von runder, amöboider Mikroglia begleitet. E. in 10-facher Vergrößerung. F. in 25-facher Vergrößerung, die Mikroglia bilden Zellarme aus und scheinen sich zu vernetzen. Des Weiteren erkennt man hier Mikrogliazellen außerhalb des Hirnschnittes inmitten von Tumorzellen (Pfeile). 


\subsubsection{Die Tumorzellen werden auf der Membran ausgesät}

Um zu verhindern, dass die Tumorzellen unspezifisch über den Hirnschnitt versprengt werden und sich in prädisponierenden, anatomischen Furchen sammeln, wird der Versuchsaufbau exemplarisch umgedreht. Das heißt, zuerst soll auf der Membran ein gleichmäßiger Zellrasen von Tumorzellen ausgesät und anschließend der Organotypische Hirnschnitt darauf platziert werden. Für diese Art von Versuchsaufbau wird nun nicht mehr die Sechs-Loch-Platte mit der Membran als Einsatz verwendet, sondern eine Lumi-dish-Kulturplatte. Diese Platte besitzt als Boden eines jeden Loches eine sauerstoffdurchlässige, transparente Membran. Auf dieser Membran erfolgt die Aussaht der Tumorzellen. Alsdann wir der Hirnschnitt über dem Tumorzellrasen positioniert und beides mit flüssigem ECM-Gel übergossen. Das ECM-Gel polymerisiert bei Temperaturen von $20^{\circ} \mathrm{C}$ zu einer festen Gel-Masse und soll so den Hirnschnitt und die sich darunter befindenden Tumorzellen am Boden der Kulturplatte fixieren. Über das Gel wird Kulturmedium in das Loch pipettiert. So erfolgt die Oxygenierung von unten durch den sauerstoffdurchlässigen Boden. Die Versorgung mit Nährstoffen findet über Diffusion durch das ECM-Gel bis hin zu dem Hirnschnitt und den Tumorzellen statt. Der Boden der Lumi-dish lässt sich von der Platte abziehen. Nach fünf Tagen in Kultur, wird das Kulturmedium aus dem Loch abgesaugt und der Boden mitsamt den Tumorzellen, dem Hirnschnitt und dem ECM-Gel entfernt. Der Boden kann dann als Ganzes auf ein Deckglas transferiert und dort eingedeckelt werden.

Bei der Auswertung der Versuche mit der Lumi-dish, ergab es sich, dass die Organotypischen Hirnschnitte nach 5 Tagen in Kultur nicht mehr vital waren. Sie erschienen ödematös aufgequollen und lytisch zersetzt. Zudem löste sich bei einigen Versuchen das ECM-Gel von dem Membranboden, so dass die Hirnschnitte frei im Medium flottierten und nicht mehr länger in Kontakt zu den Tumorzellen standen. 


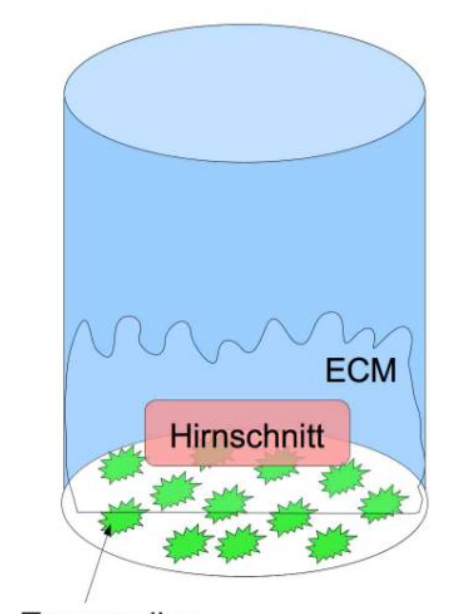

Tumorzellen

Abbildung 3.5 Tumorzellen direkt auf der Membran ausgesät Die Lumi-dish Platte besitzt einen für Sauerstoff permeablen Boden. Zuunterst erfolgt die gleichmäßige Aussäht eines Tumorzellrasens. Darüber wird der Hirnschnitt positioniert. Der Schnitt mit den darunter liegenden Tumorzellen wird mit ECM-Gel eingebettet und so am Boden der Kulturplatte fixiert. Anschließend wird über dem ECM das Nährmedium in das Loch der Lumi-dish pipettiert. Das heißt die Oxygenierung erfolgt durch den Boden und die Versorgung mit Nährstoffe per Diffusion durch das Gel bis hin zu dem Hirnschnitt und den Tumorzellen

\subsubsection{Die Tumorzellen werden in Extrazelluläre Matrix (ECM) eingebettet}

Bei der Auswertung der ersten Versuche mit den Tumorzellen kann neben der Verteilung der Zellen auch ein weiteres Phänomen beobachtet werden. Unter dem Konfokalmikroskop ist ersichtlich, dass in der obersten Schicht des Hirnschnittes sowie an der unteren Seite, also dort, wo das Vibratom geschnitten hat, amöboide Mikrogliazellen akkumulieren. Im Bereich des traumatisierten Gewebes werden Mikroglia aktiviert und bilden eine Glianarbe. Da mögliche Effekte dieser Voraktivierung der Mikroglia vermieden werden sollen, wird ein Punkt gesucht, an dem die Tumorzellen in Kontakt mit atraumatischen und intakten Hirngewebe gebracht werden können. Dafür bietet sich der Außenrand des Schnittes an (vgl. Schema in Bild 3.6).

Um einen gebündelten und definierten Kontaktpunkt der Tumorzellen mit dem Hirngewebe als möglichen Startpunkt für eine Invasion zu schaffen, werden die Zellen in eine gelartige extrazelluläre Masse eingebettet. Bei der extrazellulären Matrix (ECM) handelt es sich um das Bindegewebe, das sich zwischen den Zellen im Interzellularraum befindet. Die ECM von Sigma-Aldrich, die in dem hier eingesetzten Versuchsaufbau Verwendung findet, wird aus Engelbreth-Holm-Swarm (EHS)Sarkoma-Zellen aus Mäusen gewonnen (Referenzprotokoll, siehe Carey et al. 1986). Dieses ECM-Gel enthält Laminin, Kollagen Typ IV, Heparan-Sulfat-Proteoglycan und 
Entactin. Das ECM-Gel liegt bei $2-8^{\circ} \mathrm{C}$ in flüssiger Form vor und beginnt durch thermische Aktivierung bei $20^{\circ} \mathrm{C}$ zu polymerisieren.

Um die Tumorzellen in das ECM-Gel einzubetten, wird das Gel zunächst aus seiner Lagerung bei $-80^{\circ} \mathrm{C}$ über Nacht auf Eis aufgetaut. Die zu verwendenden Zellen werden in einer Konzentration von $1 \times 10^{5}$ Zellen $/ \mathrm{ml}$ eingesetzt. Die Zellen werden bei ca. 900 rpm für 5 min herunterzentrifugiert. Das Zellpellett kann durch Absaugen des Überstandes trockengelegt werden. Es wird anschließend in $10 \mu \mathrm{l}$ der ECM resuspendiert. Diese $10 \mu \mathrm{l}$ Zell-ECM-Suspension wird als Tropfen in eine kleine Petrischale pipettiert. Nach dem Trocknen von ca. $45 \mathrm{~min}$ im Zellkulturinkubator ist ein gel-artiger Tumorzelltropfen entstanden. Dieser Geltropfen wird mit einer feinen Einmalpasteurpipette angesaugt und neben der Außenkante des Gehirnschnittes platziert. Dies bietet zum einen den Vorteil, dass die Tumorzellen in dem Geltropfen gebündelt sind und beim Pipettieren nicht über den gesamten Schnitt versprengt werden. Zum anderen gelingt es dadurch, die Tumorzellen in dem Versuch in eine Ausgangsposition zu bringen, die näher an den in-vivo-Verhältnissen liegt. Ungeachtet dieser Verbesserung der Versuchsbedingungen kann festgestellt werden, dass trotz der Einbettung der Tumorzellen in den ECM-Tropfen vereinzelte Zellen beim Platzieren des Tumortropfens über den Hirnschnitt versprengt werden. Die Tumorzelltropfen verbleiben für 5 Tage neben dem Schnitt in Kultur. 

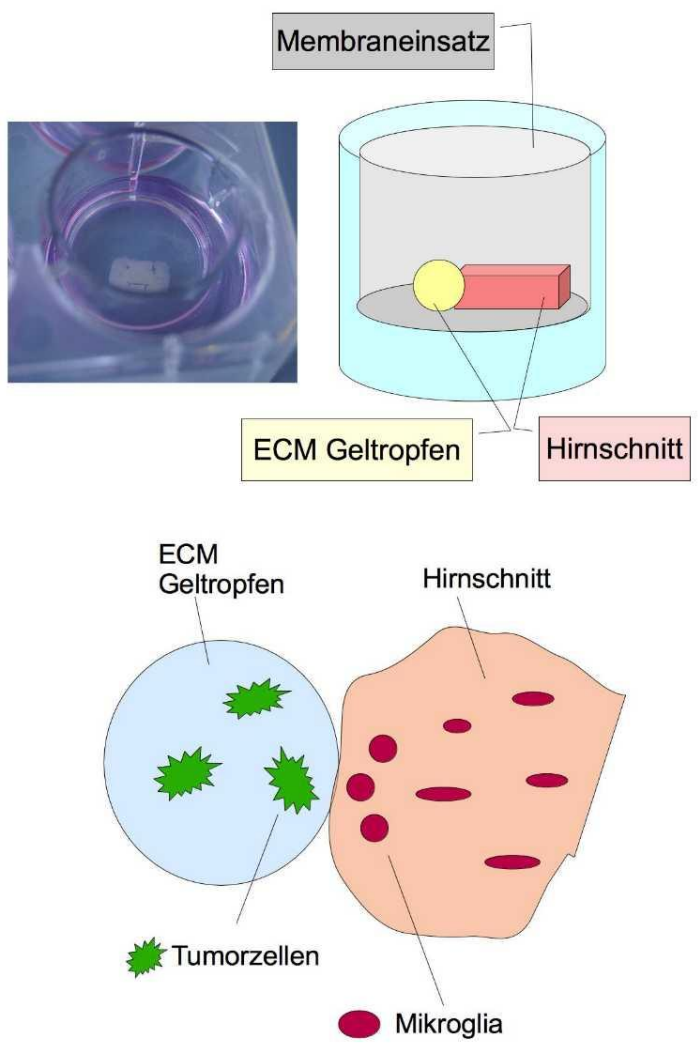

Abbildung 3.6 Schema der Position des ECM-Tropfens Der Tumor-ECM-Tropfen wird an den Außenrand des Hirnschnittes platziert. An der Ober- und Unterseite hat das Vibratom durch das Hirngewebe geschnitten.

\subsubsection{Der Hirnschnitt wird beim Pipettieren des tumorzellhaltigen ECM- Tropfens abgeschirmt}

Um den oben beschriebenen Effekt der Verschleppung der Tumorzellen zu verhindern, wird im Folgenden das Hirngewebe beim Setzen des Tumortropfens abgeschirmt. Zur Abschirmung wird ein sterilisiertes Deckglas verwendet. Dieses wird mit einer Pinzette neben der Außenkante des Hirngewebes positioniert. Das Deckglas weist dabei eine Kippung von ca. $45^{\circ}$ zum Hirnschnitt auf. An die untere Glaskante kann auf der vom Hirn abgewandten Seite die Tumorzell-ECM Masse pipettiert werden (vgl. Abbildung 3.5). Bei diesem Vorgang ist nun das Mausgehirn von den Tumorzellen von einer Glasscheibe getrennt. Nach dem Pipettieren des Tumorzell-ECM-Tropfens kann die Glasscheibe wieder entfernt werden und die zähe Gelmasse fließt langsam an den Rand des Hirnschnittes heran. Durch das Abschirmen mit der Glasscheibe wird eine Kontamination des Hirngewebes mit Tumorzellen verhindert. Folglich kann der Tumor- 
ECM-Tropfen als Startpunkt einer möglichen Invasion definiert werden, da alle Tumorzellen die nach einer Inkubationszeit von 5 Tagen in dem Schnitt gefunden werden, aus dem Gel-Tropfen in das Hirngewebe eingewandert sein müssen.

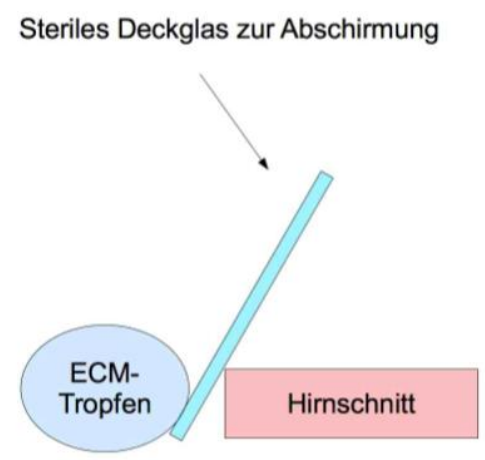

Abbildung 3.7 Verwendung eines Abstandhalters Als Abstandhalter wird ein steriles Deckglas eingesetzt. Der Tumortropfen wird gegen das um $45^{\circ}$ gekippte Glas pipettiert. So ist das Hirngewebe abgeschirmt, während der Tumortropfen gesetzt wird und es können keine Tumorzellen über den Hirnschnitt versprengt werden.

\subsection{Die Mikroglia werden in dem Hirnschnitt angefärbt}

Nach einer Kulturzeit von 5 Tagen werden die Hirnschnitte fixiert, wie unter 2.2.8 beschrieben. Da der Hirnschnitt nach der Kultur so wenig wie möglich bewegt werden soll, erfolgt die Anfärbung des Schnittes in dem Einsatz. Der Färbevorgang wird unter 2.2.9 beschrieben. Zur Darstellung der Mikroglia wird Isolectin B4 Alexa Fluor 647 eingesetzt.

\subsection{Sichere Transferierung des Hirnschnitts auf den Objektträger}

Nach dem Färbevorgang wird der Hirnschnitt auf einen Objektträger transferiert und eingedeckelt. Zunächst wurde unter Zuhilfenahme eines sehr feinen Rosshaarpinsels der Hirnschnitt um diesen Pinsel gewunden und sodann auf dem Objektträger wieder ausgerollt. Bei dieser Vorgehensweise ist eine Vielzahl der Schnitte zerrissen. Schließlich konnte eine Möglichkeit gefunden werden, den Hirnschnitt einzudeckeln, ohne ihn zu lädieren und auch ohne inn von seiner Position auf der Membran zu bewegen. Mit einem spitzen Skalpell wird nun die Insertmembran um den Schnitt 
herum ausgeschnitten, mit einer Pinzette auf den Objektträger gelegt und schließlich mit „Mounting Medium“ eingedeckelt (vgl. Abbildung 3.6).

\section{Querschnitt}

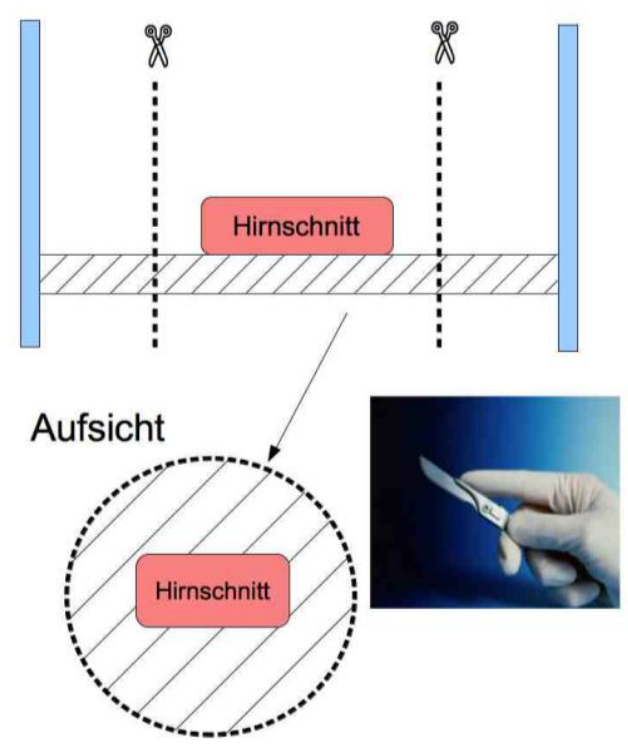

Abbildung 3.8 Der Hirnschnitt wird mitsamt der Membran ausgeschnitten Um den Hirnschnitt nach erfolgter Kultur unter dem Mikroskop zu betrachten, muss dieser auf einen Objektträger transferiert und eingedeckelt werden. Damit das Gewebe auf der Membran so wenig wie möglich bewegt wird, erfolgt ein zirkuläres Herausschneiden des Hirnschnittes mitsamt der Membran. Da die Membran durchsichtig ist, kann sie problemlos mit auf den Objektträger gebracht werden und stört nicht beim Mikroskopieren. (Quelle Foto Skalpell: http://www.capital.de/static/bilder/Redaktion/005-) 


\section{$4 \quad$ Ergebnisse der Experimente mit Ko-Kulturen}

\subsection{Ergebnisse der Konfokal-Mikroskopie}

\subsubsection{Die Tumorzellen invadieren in den Hirnschnitt}

Für die Ko-Kultur der Hirnschnitte werden zwei verschiedene Tumorzelllinien verwendet, die humane Mamma-Karzinom-Zelllinie MCF-7 sowie die HodgkinLymphom-Zelle L428. Bei beiden Zelllinien zeigen die Mikroglia im Hirngewebe eine ähnliche Reaktion. Nach fünf Tagen in Ko-Kultur finden sich bei beiden Zelllinien Tumorzellen, die aus dem ECM-Tropfen heraus in den Hirnschnitt eingewandert sind. Es lassen sich sowohl vereinzelte Zellen entdecken (vgl. Abbildung 4.1, B) als auch scheinbar in Zellverbänden wandernde Tumorzellen (vgl. Abbildung 4.1, C). Auch Zellen, die in dem Schnitt gleichsam eine Absiedlung vieler zusammengeballter Tumorzellen bilden, können beobachtet werden. Obwohl derzeit noch keine bevorzugte Zelllinie für eine Wanderung in den Hirnschnitt hinein ausgemacht werden kann, können in der Invasionsfreudigkeit der Zellen Unterschiede zwischen den beiden Zelllinien festgestellt werden. Dabei entsteht der Eindruck, dass die L428-Zelllinie besonders schnell und in großer Anzahl in den Schnitt invadiert. Etwas weniger invasiv zeigen sich die MCF-7. Diese Beobachtung wird im Rahmen dieser Arbeit nicht genauer quantifiziert, so dass derzeit keine Aussage über die prozentual oder absolut invadierte Zellzahl der L428 im Vergleich mit den MCF-7 getroffen werden kann. 

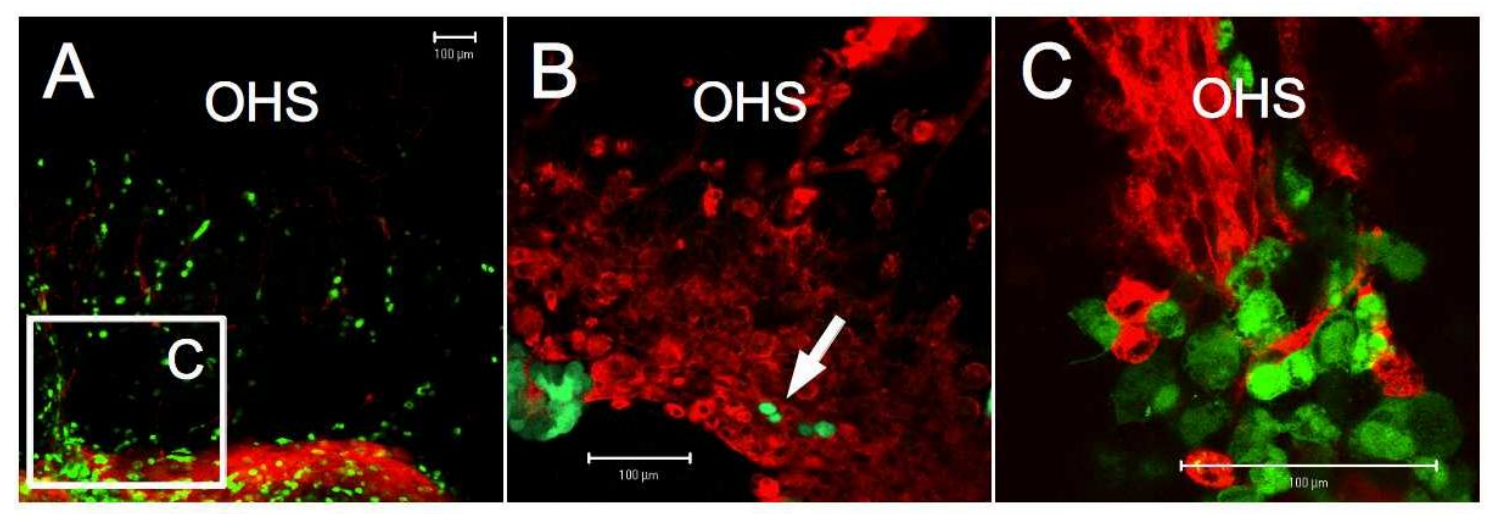

Abbildung 4.1 Die Tumorzellen wandern in den Hirnschnitt ein Rot: mit Isolectin B4 Alexa Fluor 647 angefärbte Mikroglia. Grün: Tumorzellen, mit GFP transfizierte L428 und MCF-7, die Größenmaßstäbe zeigen immer $100 \mu \mathrm{m}$. OHS kennzeichnet den Organotypischen Hirnschnitt A. Übersicht in 10-facher Vergrößerung. Die Tumorzellen wandern bevorzugt an einer Stelle ein. Hier invadieren sie entlang einer Mikrogliastraße. B. Tumorzellen im Hirnschnitt (Pfeil). C. 25-fache Vergrößerung. Mehrere Mikrogliazellen ballen sich zu einer "Straße“ zusammen, an der sich Tumorzellen entlang ranken.

\subsubsection{Mikrogliazellen sammeln sich an der Seite des Tumorzelltropfens}

In der Region, wo an der Hirnaußenseite der Tumorzell-ECM-Tropfen platziert ist, kann mit dem Konfokalmikroskop ein sehr viel stärkeres Signal für das mikrogliäre Fluorochrom Alexa 647 detektiert werden (vgl. Abbildung 4.3). Die Bilder zeigen, dass Mikroglia sich an der Seite der Tumorzellen sammeln und dort akkumulieren (vgl. Abbildung 4.2 und 4.3). Des Weiteren ist zu beobachten, dass sich zu dem Schnittrand hin, an dem die Tumorzellen liegen, eine wandähnliche Formation von Mikroglia finden lässt. Die Mikroglia bilden dort eine Art „Mauer“, an denen kleine, runde Mikrogliazellen dicht an dicht zu finden sind (für die Zelllinie L428 vgl. Abbildung 4.2, A und für MCF-7, Abbildung 4.3,A).

In Kontrollschnitten, an denen zum Vergleich an der Hirnaußenseite ein ECM-Tropfen ohne Tumorzellen positioniert wird, zeigen die Mikroglia keine solche Akkumulation zu den Tumorzellen hin. In den Kontrollschnitten kann ein homogenes Verteilungsmuster der Mikroglia detektiert werden (vgl. Abbildung 4.4). 


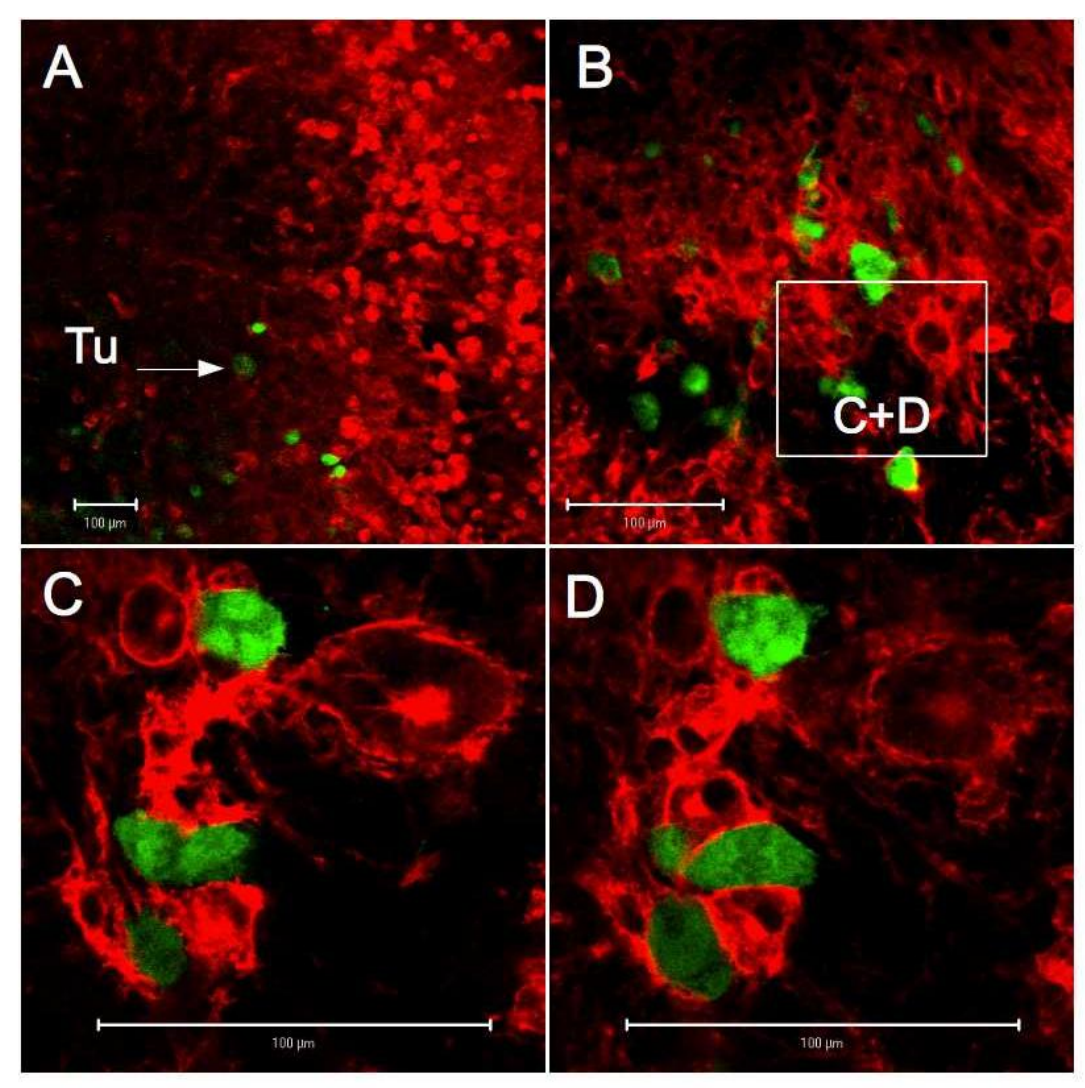

Abbildung 4.2 L428, nahe den Tumorzellen findet sich eine Gliosis aus runden Mikrogliazellen Rot: mit Isolectin B4 Alexa Fluor 647angefärbte Mikroglia. Grün: Tumorzellen, mit GFP transfizierte L428, die Größenmaßstäbe zeigen immer $100 \mu \mathrm{m}$. A. 10-fache Vergrößerung. Die Mikroglia verdichten sich nahe den Tumorzellen zu einer wandähnlichen Struktur aus kleinen kugeligen Zellen. B. 25-fache Vergrößerung. Die Tumorzellen sind eingebettet in Mikrogliazellen, Bild B zeigt die Positionen der Bilder C und $D$, die im Folgenden in einer Schichtsequenz erhoben wurden. C. 63-fache Vergrößerung Position: 5,81 $\mu \mathrm{m}$. D. 63-fache Vergrößerung Position: 8,31 $\mu \mathrm{m}$
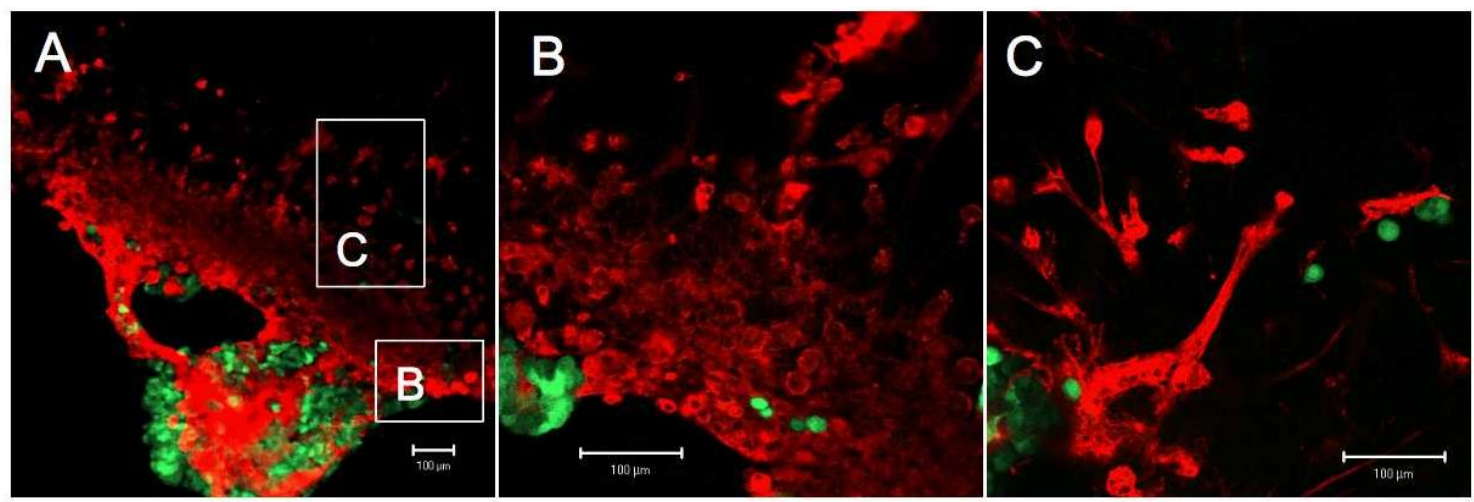

Abbildung 4.3 MCF-7, Mikroglia akkumulieren auf der Seite des Tumor-ECM-Tropfens Rot mit Isolectin B4 Alexa Fluor 647 angefärbte Mikroglia. Grün: Tumorzellen, mit GFP transfizierte MCF-7, die Größenmaßstäbe zeigen immer $100 \mu \mathrm{m}$. A. 10-fache Vergrößerung. Auch bei der humanen MammaKarzinom-Zelllinie MCF-7 zeigt sich eine Ansammlung von Mikroglia in der Nähe der Tumorzellen, Bild A zeigt die Position der Bilder B und C. B. 25-fache Vergrößerung. Die Mikroglia liegen als runde, kugelige Zellen dicht an dicht. C. 25-fache Vergrößerung. Neben den runden Zellen lassen sich auch Mikroglia finden, die verdickte Arme ausbilden. 


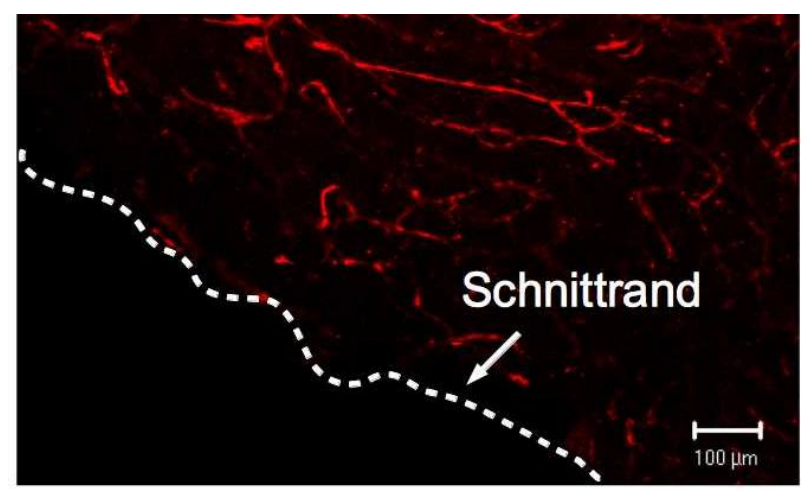

Abbildung 4.4 Leerkontrolle, Hirnschnitt ohne Tumorzellen Rot: mit Isolectin B4 Alexa Fluor 647 angefärbte Mikroglia, die Größenmaßstäbe zeigen immer $100 \mu \mathrm{m}$. A 10-fache Vergrößerung. Kontrolle, neben dem Hirnschnitt wurde ein ECM-Gel-Tropfen gesetzt, der keine Tumorzellen enthielt. Man kann ein homogenes Verteilungsmuster der ramifizierten Mikroglia erkennen, das für „ruhende“ Mikroglia spricht.

\subsubsection{Im Kontakt mit Tumorzellen zeigen Mikroglia eine typische Morphologie}

In allen Versuchen, bei denen Mikroglia mit Tumorzellen in Kontakt kommen, fällt immer wieder eine positionsabhängige typische Morphologie der Mikrogliazellen auf: In den Kontrollschnitten, in denen sich keine Tumorzellen befinden, zeigen die Mikroglia ein ramifiziertes Äußeres mit schmalen, weit verbreiterten Ausläufern (vgl. Abbildung 4.4). In den Schnitten, die mit den Tumorzellen kultiviert werden, lassen sich vor allem in Richtung auf die Tumorzellen amöboide, kleine, kugelige Mikrogliazellen erfassen, die sehr dicht beieinander stehen (vgl. Abbildung 4.2 und 4.3). Neben diesem Phänotyp kann ferner eine weitere Erscheinungsform beobachtet werden. Einige Mikrogliazellen am Rand zu den Tumorzellen weisen ebenfalls Ausläufer auf. Diese unterscheiden sich hingegen deutlich von den Ramifizierungen in den Kontrollschnitten. Hier sind die Ausläufer nicht so lang und verzweigt. Die Zellen weisen dicke „Arme“ auf mit synapsenähnlichen Formationen. Diese Synapsen lassen sich häufig in direkter Nachbarschaft zu den Tumorzellen finden, wobei sie bei einigen den Zellleib mit ihren synpasenähnlichen Ausläufern umschließen. Diese Morphologie der Mikroglia kann bei beiden Tumorzellinien, den MCF-7 und den L428 in gleicher Weise beobachtet werden (für die Zelllinie L428 vgl. Abbildung 4.4, für die MCF-7, vgl. Abbildung 4.5). 


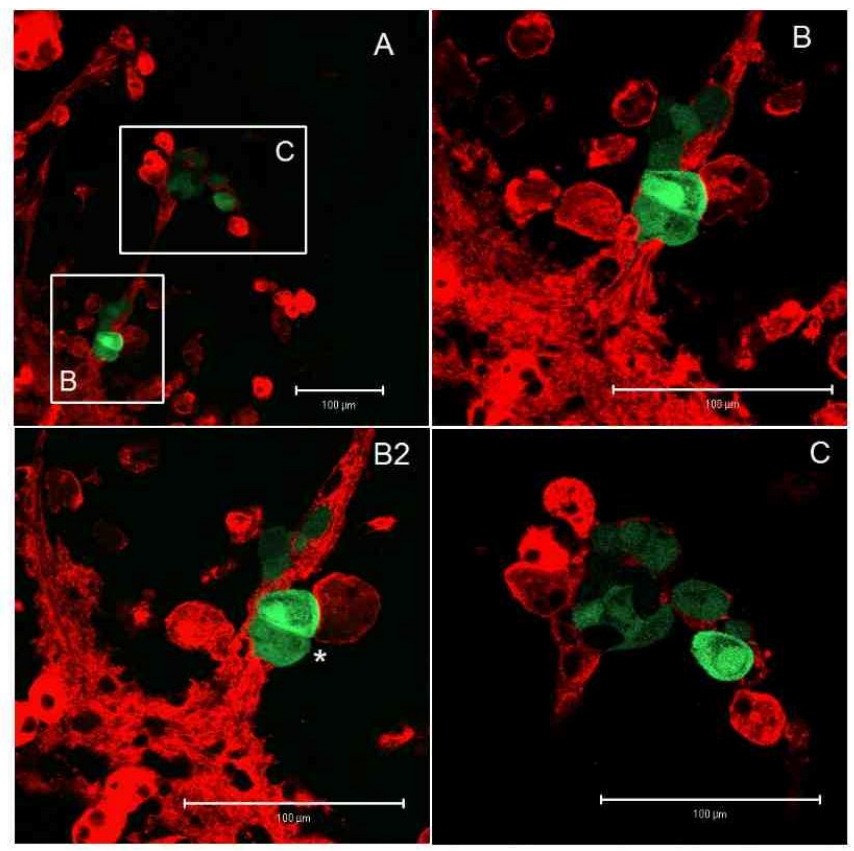

Abbildung 4.5 MCF-7 Tumorzellen ranken sich an den verbundenen Ausläufern der Mikrogliazellen entlang Rot: mit Isolectin B4 Alexa Fluor 647 angefärbte Mikroglia. Grün: Tumorzellen, mit GFP transfizierte MCF-7-Zellen, die Größenmaßstäbe zeigen immer $100 \mu \mathrm{m}$. A. 25-fache Vergrößerung. Die Ausläufer der Mikroglia bilden eine straßenartige Verbindung an denen sich angelagerte Tumorzellen finden lassen. Bild B, B2 und C sind mit einer 63-fachen Vergrößerung aufgenommen. B Tumorzellen ranken sich um dicke Mikrogliaarme. B2. Der Stern kennzeichnet einen synapsenartigen Kontakt zwischen einer Tumor- und einer Mikrogliazelle. C. Tumorzellkolonie, die von runden Mikrogliazellen umgeben ist.

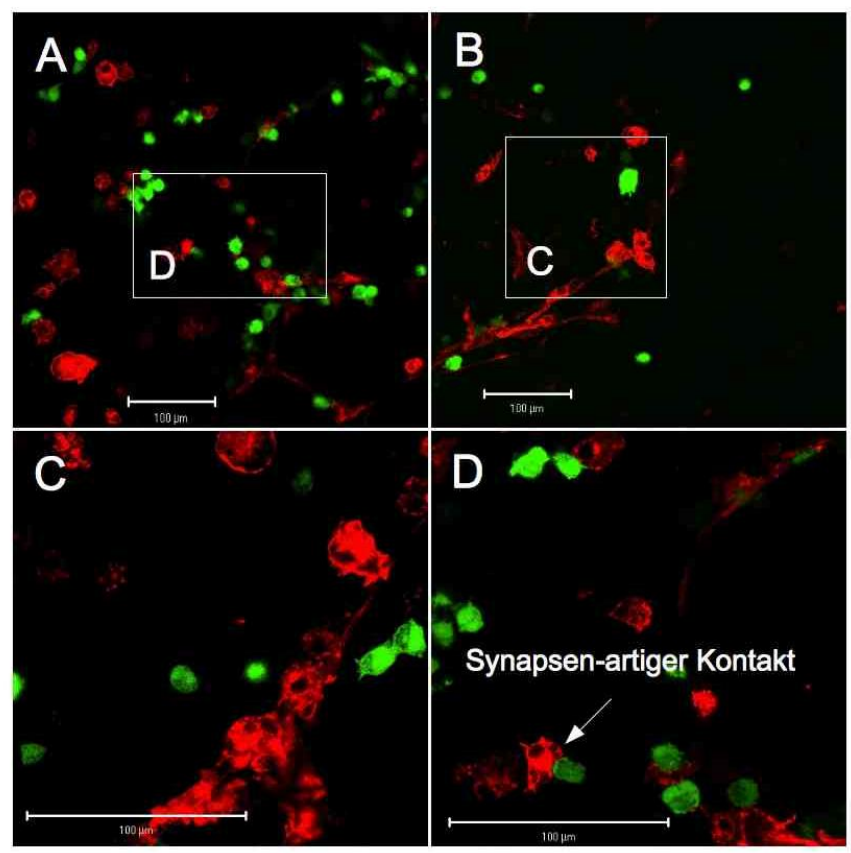

Abbildung 4.6 Die Mikroglia umschließt Tumorzellen mit synapsenartigen Ausläufern Rot: mit Isolectin B4 Alexa Fluor 647 angefärbte Miroglia. Grün: Tumorzellen, mit GFP transfizierte L428. A. 25fache Vergrößerung. Die Mikroglia bildet lange Arme aus, an denen sich die Tumorzellen entlang aufreihen. B. 25-fache Vergrößerung. C. 63-fache Vergrößerung. Hier stellt sich dar, dass die langen Arme aus mehreren Mikrogliazellen bestehen, die sich zusammenlagern. D. 63-fache Vergrößerung. Am linken Bildrand ist eine Mikrogliazelle zu erkennen, die die benachbarte Tumorzelle synapsenartig umschließt. 


\subsubsection{Mikroglia invadieren in den Tumorzelltropfen}

In den Untersuchungen des Tumor-ECM-Tropfens fällt eine sehr überraschende Entdeckung ins Auge. Nach den fünf Tagen in Ko-Kultur mit den Hirnschnitten lassen sich in dem ECM-Gel Mikrogliazellen finden, die offensichtlich aus dem Schnitt heraus in den Tumortropfen gewandert sind. Diese Mikrogliazellen weisen meist eine runde, kugelige Form auf (vgl. Abbildung 4.6, D). Häufig lässt sich feststellen, dass diese Mikroglia in dem ECM-Tropfen sich in unmittelbarer Umgebung zu den Tumorzellen befindet. Es entsteht hierdurch der Eindruck, dass Mikroglia den Kontakt zu den Tumorzellen förmlich sucht. Diese Hypothese wird zu einem späteren Zeitpunkt mit der Time-Lapse-Methode bestätigt (vgl. Abbildung 4.9 und 4.10). Weiterhin kann die Beobachtung für beide Tumorzelllinien gleichermaßen beschrieben werden.

\subsubsection{Mikroglia ebnen den Tumorzellen den Weg in das Hirngewebe}

Ein weiterer erstaunlicher Effekt kann an dem Kontaktpunkt, wo der Tumor-ECMTropfen an dem Hirngewebe anliegt, beobachtet werden. Zwischen dem ECM-Tropfen und dem Hirngewebe formen sich die Mikrogliazellen an dem Rand des Schnittes zu langen, spindelförmigen Ausziehungen (vgl. Abbildung 4.7, B und C). Mit ihren Ausläufern hintereinander aufgestellt, bilden sie eine „Straße“ von Mirkogliazellen zwischen ECM-Tropfen und Hirngewebe. Um diese Mirkoglia herum und in diese Struktur hinein eingebettet, lassen sich Tumorzellen detektieren (vgl. Abbildung 4.7, C). Augenscheinlich wandern die Tumorzellen entlang dieser Mikrogliastraßen in den Schnitt ein. 


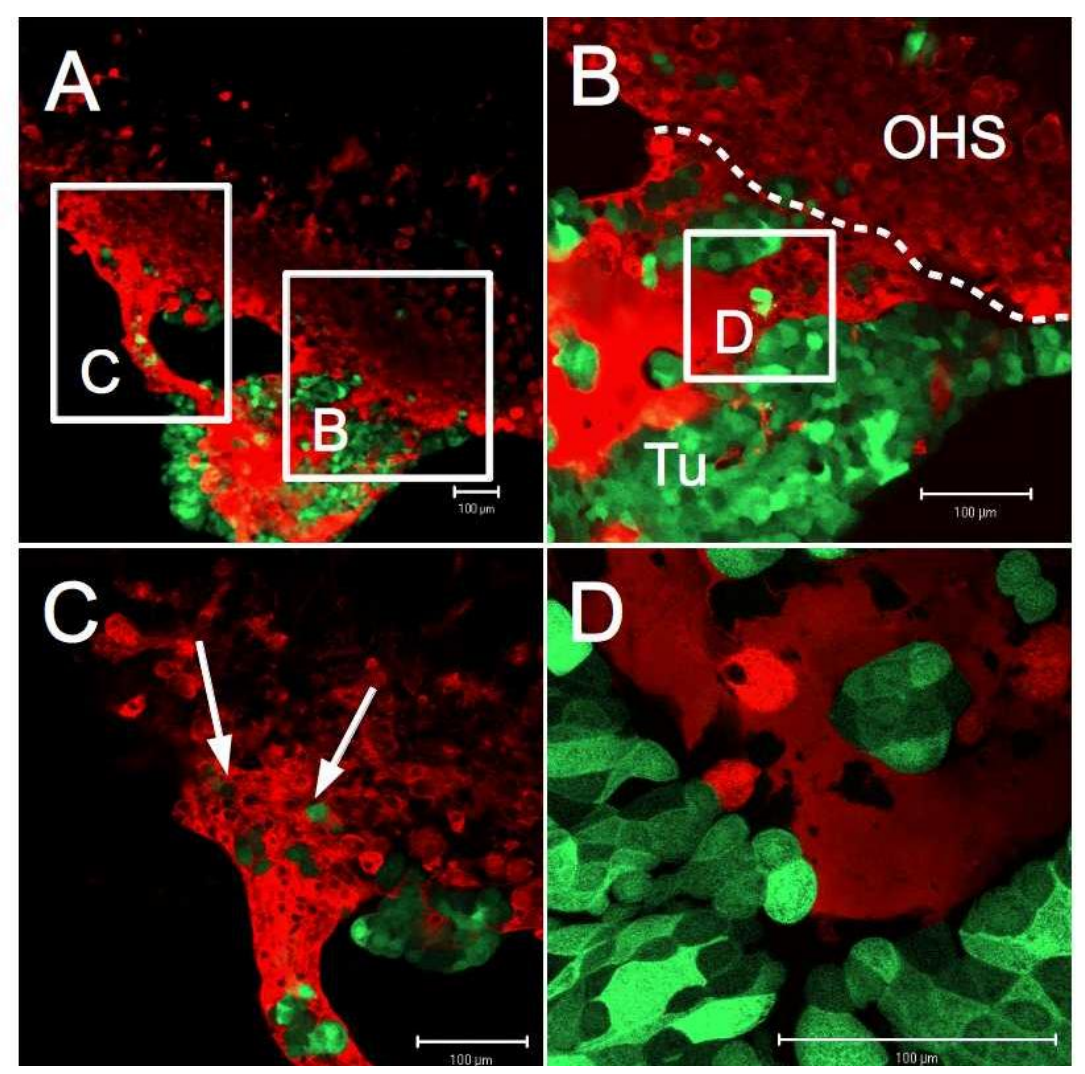

Abbildung 4.7 MCF-7, Die Tumorzellen invadieren in den Hirnschnitt und die Mikroglia in den Tumor-ECM-Tropfen Rot, mit Isolectin B4 Alexa Fluor 647 angefärbte Mikroglia. Grün, Tumorzellen, mit GFP transfizierte MCF-7. A. 10-fache Vergrößerung. In der unteren Bildhälfte befindet sich der TumorECM-Tropfen. B. In Bild B ist in 25-facher Vergrößerung die Grenze zwischen dem Organotypischen Hirnschnitt (OHS) und dem Tumor-ECM-Tropfen (Tu) eingezeichnet. Es ist zu erkennen, dass sich runde Mikroglia an dem Rand des Hirnschnittes sammeln. Weiterhin ist zu sehen, dass Mikrogliazellen über die Schnittgrenze hinaus in den Tumor-ECM-Tropfen eingewandert sind. C. Die Pfeile sollen verdeutlichen, dass Mikroglia scheinbar auf den Geltropfen zuströmt. D. Bild D verdeutlicht mit 63-facher Vergrößerung, dass sich Mikrogliazellen im Tumor-ECM-Tropfen befinden.
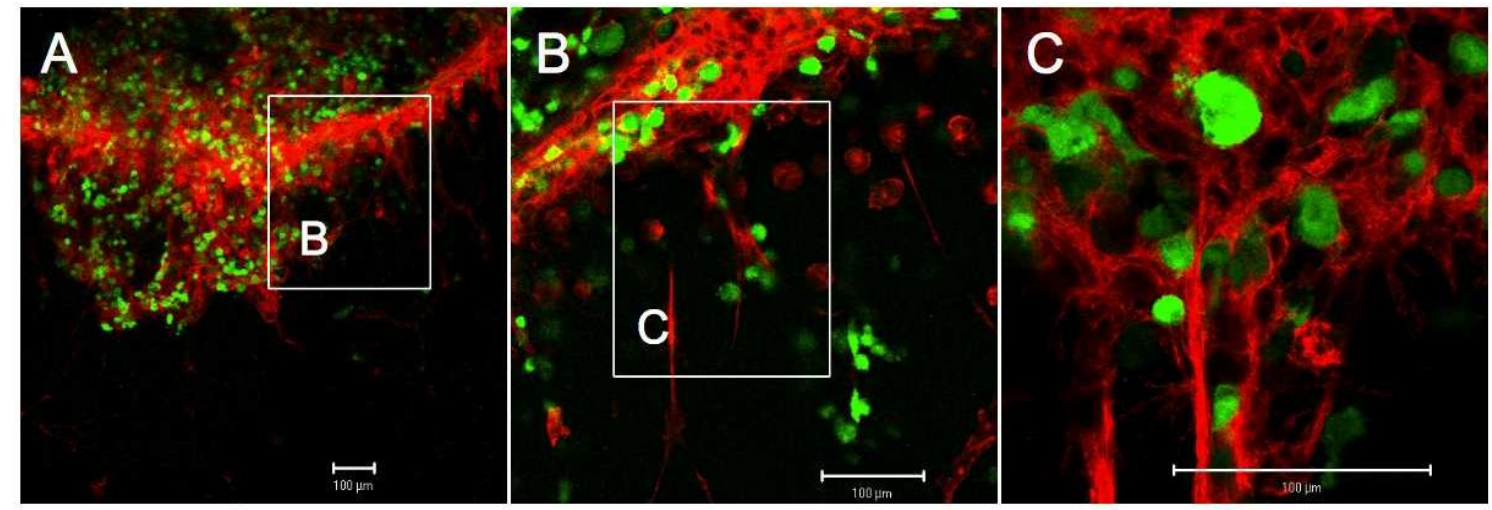

Abbildung 4.8 L428, „Straße“ aus Mikroglia als Führungsschiene für die Tumorzellen Rot: mit Isolectin B4 Alexa Fluor 647 angefärbte Mikroglia. Grün: Tumorzellen, mit GFP transfizierte L428 A. 10fache Vergrößerung. In der oberen Bildhälfte befindet sich der Tumor-ECM Tropfen. An der Grenze zwischen Hirngewebe und dem Geltropfen haben sich Mikroglia zu einer Wand verdichtet. Man erkennt zackenförmige Ausläufer roter Mikrogliazellen, die in das Hirngewebe hineinragen. B. In der 25-fachen Vergrößerung sind Mikrogliastraßen zu sehen, die in das Hirngewebe hineinragen. C. Das Bild C verdeutlicht in 63-facher Vergrößerung, dass sich entlang der Mikrogliastraßen Tumorzellen befinden, die in Richtung auf das Hirngewebe entlang der Mikroglia als „Führungsschiene“ migrieren. 


\subsection{Ergebnisse der Time-Lapse-Mikroskopie: Der „,tödliche Kuss" der Mikroglia}

Mit der Time-Lapse-Mikroskopie können vorher festgelegte Positionen des Schnittes über mehrere Tage beobachtet werden. Dabei wird von diesen Positionen in regelmäßigen Zeitabständen ein Bild aufgenommen. Diese Bilder können anschließend zu einem Film zusammengesetzt werden. Bei dieser Methode lässt sich zunächst feststellen, dass sowohl außerhalb des Schnittes wie auch in dem Schnitt selbst eine rege Zellbewegung stattfindet. Darüber hinaus kann eine Vielzahl kleiner Zellen entdeckt werden, die aus dem Schnitt heraus wandern. Diese Zellen bewegen sich auf die Tumorzelle zu, scheinen dort Kontakt mit den Tumorzellen aufzunehmen und wandern auch wieder zum Hirngewebe zurück. Dabei gibt es kleine Zellen, die ihre runde Form zu einer verzweigten ändern und mit weiteren Zellen dieser Art eine lange „Straße“ bilden. Diese straßenartige Struktur reicht weit in den Tumorzell-ECM-Tropfen hinein. An dieser Struktur lagern sich die mit EGFP markierten Tumorzellen an und migrieren daran entlang in das Hirngewebe hinein (vgl. Abbildung 4.10, Bildsequenz B1-B6) So wirken diese Zellstraßen zwischen Hirngewebe und ECM-Tropfen wie „Brücken“, über welche die Tumorzellen in das Hirngewebe eindringen. Im späteren Verlauf derartiger Untersuchungen konnte gezeigt werden, dass es sich bei den kleinen, runden Zellen um Mikroglia handelt (Pukrop et al. 2010).

Es kann noch ein zweiter Mechanismus aufgedeckt werden, wie die Tumorzellen in das Hirngewebe gelangen. In mehreren Fällen konnte in aufeinanderfolgenden Bildsequenzen erfasst werden, wie Mikroglia mit ihren „Armen“ einzelne Tumorzellen umschließt und diese dann in den Hirnschnitt hinein zieht (vgl. Abbildung 4.9, Bildsequenz A1-A6).

In Abbildungen 4.9 und 4.10 sind jeweils ausgewählte Bilder in einem Zeitrahmen zwischen 36 und 48 Stunden zu sehen. 

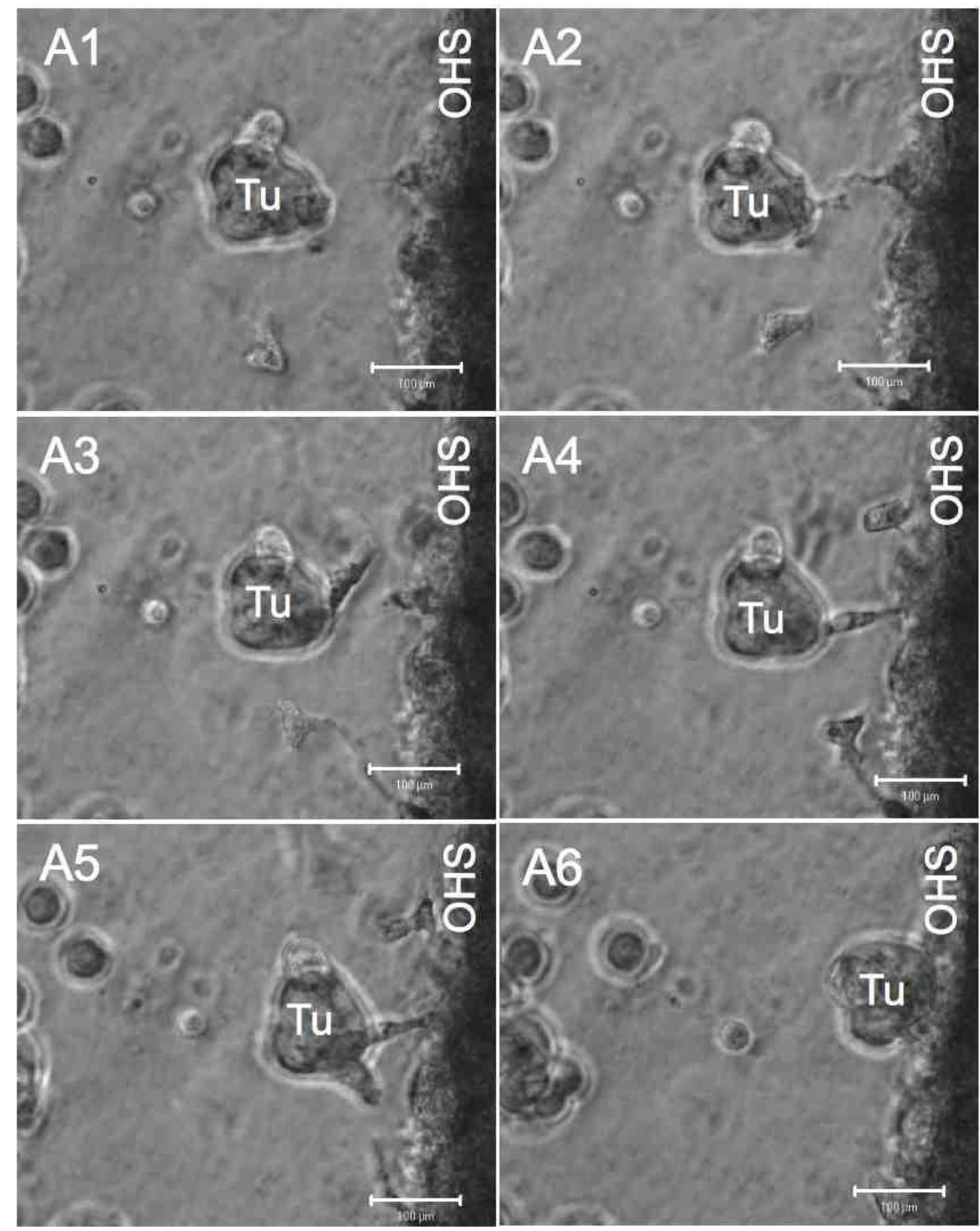

Abbildung 4.9 Time-Lapse-Mikroskopie eines Organotypischen Hirnschnittes in Ko-Kultur mit einem Tumor-ECM-Tropfen (Pukrop et al., 2010) Tu: Tumorzellen. OHS: Organotypischer Hirnschnitt, gezeigt sind ausgesuchte Zeitpunkte zwischen $36 \mathrm{~h}$ und 48h in Phasen Kontrast, die vollständige Sequenz befindet sich im beiliegenden Video im Zusatzmaterial, die Größenmaßstäbe zeigen immer $100 \mu \mathrm{m}$. A1 die Tumorzelle liegt vor dem Hirnschnitt. A2 ein erster Zellfortsatz bewegt sich aus dem Hirnschnitt auf die Tumorzelle zu. A3 und A4. Weitere „Fangarme“ wachsen auf die Tumorzelle zu A5. Die Tumorzelle wird schließlich durch drei „Fangarme“ umschlossen und A6. In den Hirnschnitt hineingezogen. 

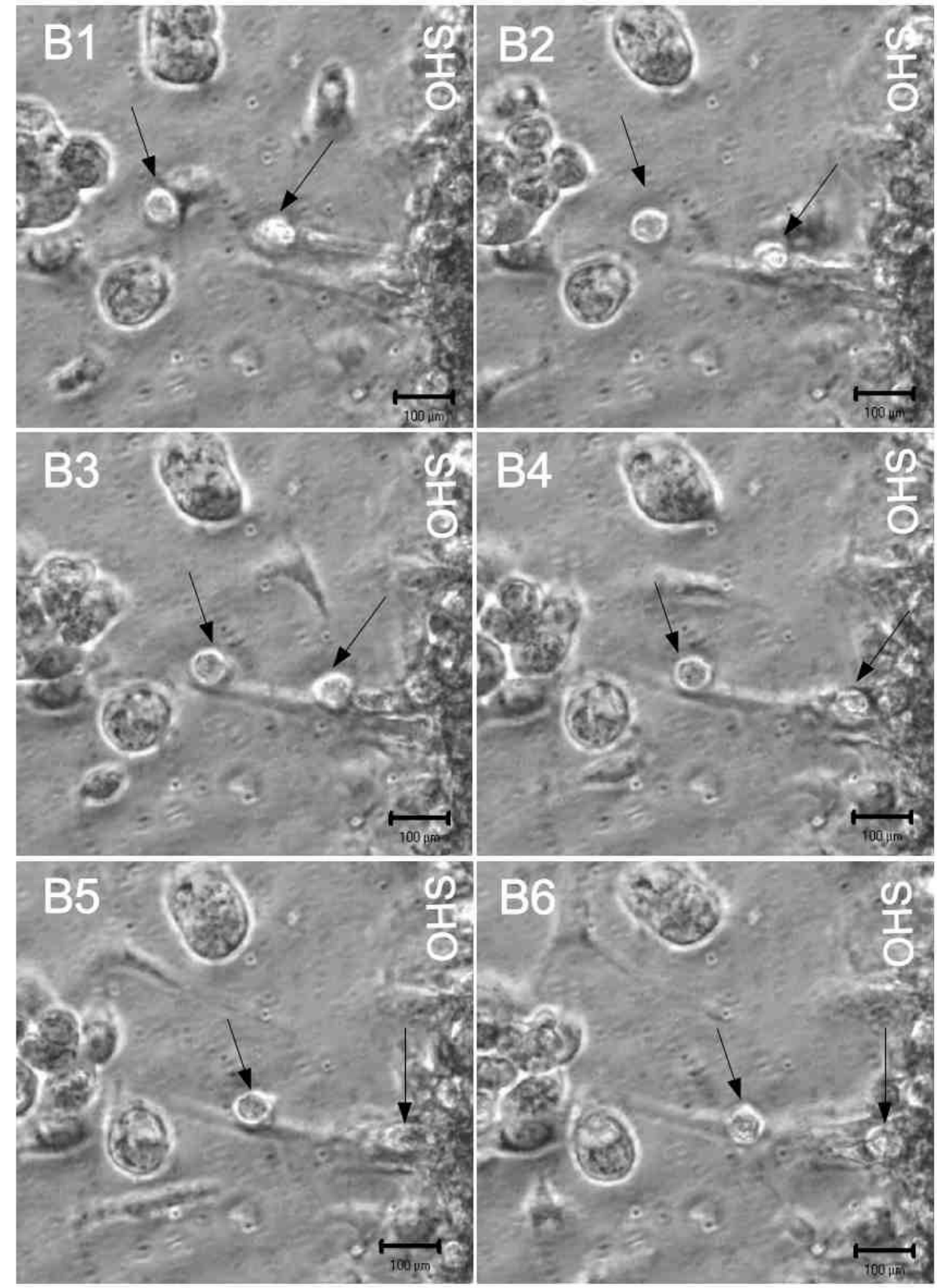

Abbildung 4.10 Time-Lapse-Mikroskopie eines Organotypischen Hirnschnittes in Ko-Kultur mit einem Tumor-ECM-Tropfen (Pukrop et al., 2010) Pfeile Tumorzellen. OHS: Organotypischer Hirnschnitt, gezeigt sind ausgesuchte Zeitpunkte zwischen $36 \mathrm{~h}$ und $48 \mathrm{~h}$ in Phasen Kontrast, die vollständige Sequenz befindet sich im beiliegenden Video im Zusatzmaterial, die Größenmaßstäbe zeigen immer $100 \mu \mathrm{m}$. B1B6: Die Tumorzellen „rollen" auf einem Zellfortsatz wie auf einer Führungsschiene in das Hirngewebe hinein. 


\section{$5 \quad$ Diskussion der Methodenentwicklung}

Um die Wechselbeziehungen zwischen Tumorzellen und Mikroglia beobachtbar zu machen, ist es essentiell, sie unter physiologischen Bedingungen zu untersuchen. Die Gewährleistung physiologischer Bedingungen über die gesamte Versuchsdauer ist nicht trivial. Nachfolgend wird das in Kapitel 3 beschriebene Vorgehen diskutiert und begründet.

\subsection{Etablierung der Organotypischen Hirnschnittkultur}

Es gelang, die Organotypische Hirnschnittkultur mit 5-7 Tage alten NMRI-Mäusen durchzuführen. Allgemein sind für die Organotypische Hirnschnittkultur Nagetiere (Rodentia) im postnatalen Stadium (Tag 0 bis Tag 7) geeignet. In diesem Alter ist die Zytoarchitektur des Hirngewebes bereits vollständig entwickelt und die Nervenzellen tolerieren die Präparation (Gähwiler et al.1997).

Die meisten Arbeitsgruppen verwenden zur Gewinnung Organotypischer Schnitte das Gehirn von Ratten. Dies bietet den Vorteil, dass das größere Rattengehirn sich leichter präparieren lässt und sich durch höhere Stabilität bei der Präparation auszeichnet. Wie jedoch De Simoni und MY Yu erörtern, ist die Verwendung anderer Nagerspezies, wie der Maus, problemlos möglich (De Simoni und My Yu 2006). Um eine syngene KoKultur zu schaffen, wurde für die vorliegende Arbeit die Maus als Ko-Kulturmodell etabliert. Zwar bedurfte es zur Präparation des kleineren und fragileren Mäusegehirns einer gewissen Übung und großer Sorgfalt, darüber hinaus gestaltete sich jedoch die Kultur der Mäusegehirne problemlos. Die Rezepturen für das Präparations- sowie für das Inkubationsmedium konnten von der Arbeitsgruppe von Faramarz Dehghani, Dr. Senckenbergische Anatomie, Goethe Universität, Frankfurt am Main übernommen werden (Kohl et al. 2003, Dehghani et al. 2004, Kreutz et al. 2009). Unter Verwendung der Agarblöcke zur Abstützung des Gehirnes konnte das kleine Mäusegehirn ausreichend stabilisiert werden. Ohne die Agarblöcke schert das kleine Mausgehirn von dem Vibratomteller $\mathrm{ab}$, da es den Vibrationen nicht standhält. Doch durch die Abstützungsmethode mit einem Kopf- und zwei Seitenteilen ist das Schneiden mit dem Vibratommesser möglich. Insgesamt konnte die Methode soweit optimiert werden, dass sie reproduzierbar gelang. 
Bislang wurde bei vielen Autoren die Hirnregion des Hippokampus zur Organotypischen Schnittkultur verwendet (Stoppini et al. 1991, Kohl et al. 2003, Dehghani et al. 2004, Kreutz et al. 2009). Der Hippokampus ist in der Organotypischen Hirnschnittkultur die meistuntersuchte Hirnregion (Gähwiler et al. 1997). Es zeigte sich allerdings ein essentieller Nachteil bei der Präparation des Hippokampus: An den Schnittstellen entsteht traumatisiertes Gewebe, da bei nahezu jeder Art von Hirnläsion eine Aktivierung von Mikroglia erfolgt (Eyüpoglu et al. 2003). Darüber hinaus ergab sich bei der Entwicklung der Ko-Kultur, dass die Schnittstellen prädisponierende Furchen darstellen in der die Tumorzellen akkumulieren. Auf diesen Punkt wird in der Diskussion der Ko-Kultur Entwicklung eingegangen. Um einen solchen Störeffekt der prädisponierenden Akkumulation der Tumorzellen zu vermeiden bringt jedoch eine Umstellung vom Hippokampus zum Großhirnschnitt einen entscheidenden Vorteil. Arbeitsgruppen, die vornehmlich die hippokampale Schnittkultur einsetzen, untersuchen Mikrogliaaktivierung und die Auswirkung auf Neuronenschäden nach toxischer Hirnläsion (Bsp. Kreutz et al. 2009). Im Gegensatz dazu soll in dieser Arbeit ein Beitrag zur Untersuchung zerebraler Metastasierung geleistet werden. Es ist allgemein bekannt, dass zerebrale Metastasen multilokulär im Gehirn auftreten und sich nicht auf distinkte Regionen, wie beispielsweise den Hippokampus, beziehen. Aus diesem Grund ist es weiterhin vorteilhaft, wenn zur Untersuchung zerebraler Metastasierung ein Ganzhirnschnitt zum Einsatz kommt.

\subsection{Entwicklung der Ko-Kultur}

Als ein innovatives Element der Interface-Methode wird eine Ko-Kultur von epithelialen Mamma-Karzinom (MCF-7)-Zellen mit dem Organotypischen Hirnschnitt vorgestellt. Somit wurde dieses Verfahren erfolgreich modifiziert und eine bisher noch nicht beschriebene Ko-Kultur zwischen vitalem Hirngewebe und epithelialen Tumorzellen nicht hirneigener Herkunft geschaffen, die den Vorgang der Kolonisation des Gehirns durch Karzinomzellen modellartig abbilden kann.

Dabei ist die Idee einer Hirnschnitt-Ko-Kultur nicht neu. Verschiedene Ko-Kultur Modelle sind zuvor von anderen Autoren beschrieben worden. Ein Beispiel für eine indirekte Ko-Kultur zwischen einem organtypischen Hirnschnitt und Makrophagen wurde von Brana et al. erörtert. Hierbei wird ein Organotypischer Hirnschnitt zusammen mit einer murinen Makrophagen-Zell-Linie (RAW 264.7) kultiviert. In dem Modellansatz von Brana sind beide Kultursysteme von einer semi-permeablen 
Membran getrennt. Diese semipermeable Membran erlaubt den Austausch löslicher Faktoren zwischen den Makrophagen und dem Hirnschnitt. Brana konnte mit diesem Modell zeigen, dass lösliche Mediatoren der Makrophagen einen neurotoxischen Effekt auf das Hirngewebe ausüben (Brana et al. 1999). Diese Ko-Kultur dient folglich dazu, die Kommunikation über lösliche Signalstoffe zwischen Hirnschnitt und Makrophagen zu untersuchen.

Demgegenüber wurde eine direkte Ko-Kultur von Jeong-Ah Kim dargestellt. In dieser direkten Kultur zweier Hirnschnitte, wird ein Teil des Gyrus dentatus auf einen vollständigen hippokampalen Schnitt transplantiert (Kim et al. 2003). Mit Hilfe dieses Modells lassen sich neuroplastische Vorgänge, wie das Ausbilden neuer Nervenzellfortsätze zwischen den beiden Hirnschnitten, veranschaulichen.

Des Weiteren wurde auch eine Ko-Kultur zwischen mesenchymalen, hirneigenen Tumorzellen und einem Organotypischen Hirnschnitt durchgeführt (Matsumura et al. 2000). Bei der von Matsumura beschriebenen Ko-Kultur wird ein Sphäroid mit Gliomzellen auf einem Organotypischen Hirnschnitt platziert. Nach 24 Stunden konnte eine ungerichtete Invasion der Gliomzellen in das Hirngewebe hinein beobachtet werden.

Diese drei exemplarisch genannten Modelle analysieren zelluläre und molekulare Vorgänge im Hirnschnitt. Jedoch war es mit keiner dieser bisherigen Methoden möglich, den direkten physiologischen Kontakt zwischen Tumorzellen, Mikroglia und dem Hirnparenchym darzustellen. Erst mit der in Kapitel 5 beschriebenen Vorgehensweise ist es gelungen, ein Ko-Kulturmodell herzustellen, mit welchem die Interaktionen zwischen Tumorzellen und dem Hirngewebe erfassbar sind. Außerdem konnte erstmalig eine bisher noch nicht beschriebene Ko-Kultur zwischen einer epithelialen Tumorzelle nicht hirneigener Herkunft und dem Hirngewebe etabliert werden.

In den ersten Versuchen dieser Arbeit, eine Ko-Kultur mit Mamma-Karzinom Zellen zu generieren, wurden zunächst die malignen Zellen direkt auf einen hippokampalen Schnitt pipettiert. Dabei stellte sich heraus, dass die Tumorzellen sich an den Außenrändern des Hippokampus, an den Schnittstellen der Präparation und in anatomischen Furchen, wie beispielsweise dem Cornu temporale des Seitenventrikels sammelten. Um einen solchen Störeffekt zu verhindern, wurde anschließend die 
Organotypische Hirnschnittkultur mit dem gesamten Koronarschnitt des Gehirns durchgeführt. Der Ganzhirnschnitt war nach außen glatt begrenzt und die prädisponierenden Furchen konnten vermieden werden, was die Vorraussetzung für eine homogene und definierte Aussaat der Tumorzellen darstellte.

\subsubsection{Ausäen der Tumorzellen auf der Membran}

Bei der exemplarischen Durchführung eines umgekehrten Versuchsaufbaus mit der Lumi-dish wurde am Boden der Kulturplatte auf einer für Sauerstoff durchlässigen Membran ein Rasen von Tumorzellen ausgesät. Sekundär erfolgte die Platzierung des Organotypischen Hirnschnittes auf den Tumorzellen, und beide wurden sodann mit ECM-Gel fixiert. Bei diesem Versuch zeigten sich der Hirnschnitt nach 5 Tagen in Kultur ödematös aufgequollen und teils lytisch zersetzt. Weiterhin löste sich in einigen Versuchsreihen das ECM-Gel vom Boden der Lumi-dish ab, so dass der Hirnschnitt frei im Medium flottierte und nicht länger in Kontakt mit den Tumorzellen stand.

Es lässt sich vermuten, dass der Hirnschnitt unter dem ECM-Gel nicht ausreichend mit Nährstoffen bzw. $\mathrm{O}_{2}$ versorgt ist. Zum einen könnte dies an der Permeabilität der Bodenmembran liegen. Vielleicht ist dort die Fraktion an Sauerstoff, die in die Membran penetriert, nicht ausreichend zur Oxygenierung des Hirngewebes. Bei den Versuchen mit der 6-Loch-Platte liegt der Hirnschnitt auf der Einsatz-Membran und steht an seiner Oberfläche in direktem Sauerstoffaustausch. Eine weitere Ursache für den ödematösen, lytischen Hirnschnitt könnte in der Versorgung mit Nährstoffen liegen. Die Nährstoffe müssen in dem Versuchsaufbau der Lumi-dish aus dem Nährmedium heraus durch das ECM-Gel hindurch diffundieren, um das Hirngewebe zu erreichen. Hier könnte der Weg durch das Gel zu weit sein, so dass die Diffusion mit Nährstoffen zu lange Zeit in Anspruch nimmt und in den 5 Tagen der Kultur nur in insuffizienter Konzentration das Hirngewebe erreicht. In dem ursprünglichen Versuchsaufbau der Interface Methode schwimmt der Hirnschnitt mit der Membran direkt auf dem Nährmedium. Auf Grund dieser Beobachtung werden alle folgenden Versuche weiter mit der Interface Technik mit 6-Loch-Platte und dem Membraneinsatz durchgeführt und der Versuchsansatz mit der Lumi-dish verlassen.

\subsubsection{Einbettung der Tumorzellen in einen ECM-Gel-Tropfen}

In den ersten Versuchen, ein in-vitro-Ko-Kulturmodell zwischen Tumorzellen und dem Organotypischen Hirnschnitt zu schaffen, wurde eine definierte Menge der stabil mit einem GFP-Konstrukt transfizierten Tumorzelllinie auf den Schnitt pipettiert. Dabei 
konnte festgestellt werden, dass die optimale Zellkonzentration bei $1 \times 10^{5}$ Zellen/ml lag. Weiterhin ergab sich aus diesen ersten Versuchen, dass die Tumorzellen, wenn sie als Tropfen mittig auf den Hirnschnitt gegeben wurden, nicht im Zentrum des Schnittes liegen bleiben. Bereits nach 24 Stunden waren die Tumorzellen zirkulär an die Außenränder des Schnittes gewandert. Sie sammelten sich in Furchen und Vertiefungen des Hirngewebes und zeigten insgesamt eine recht diffuse Versprengung über den gesamten Koronarschnitt, so dass schwer zu beurteilen war, ob die im Schnitt befindlichen Tumorzellen das Hirngewebe tatsächlich via aktiver Invasion kolonisiert hatten.

Ferner zeigte sich unter dem Konfokalmikroskop, dass sich in der obersten Schicht des Koronarschnittes sowie an der Unterseite, also dort, wo das Vibratom geschnitten hatte, amöboide Mikrogliazellen sammelten. Bei nahezu jeder Art von Hirnläsion erfolgt die Aktivierung von Mikroglia (Eyüpoglu et al. 2003), beziehungsweise deren aktive Umschaltung hin zu einem reagierenden Status (Hanisch und Kettenman 2007). Aktivierte Mikroglia sind gekennzeichnet durch einen amöboiden Zelltyp, durch phagozytische Aktivität und der Produktion von inflammatorischen und zytotoxischen Faktoren (Giulian et al. 1989). Entsteht ein Schaden im Hirngewebe, erfolgt allerdings nicht nur die Aktivierung von Mikroglia. Auch Astrozyten werden aktiviert und bilden zusammen mit den Mikrogliazellen eine reaktive Gliose (Giulian 1993). Mikroglia und Astrozyten hypertrophieren, infiltrieren den Bereich des traumatisierten Gewebes und formen dort eine Glianarbe (Fitzgerald et al. 2008, Streit et al. 2005, Sofroniew 2005). Da mögliche Effekte dieser Voraktivierung der Mikroglia sowie der Bildung von Narbengewebe vermieden werden sollte, wurde eine Stelle gesucht, an der die Tumorzellen in Kontakt mit atraumatischen und intakten Gewebe gebracht werden können. Dafür bot sich der Außenrand des Schnittes an.

Um einen gebündelten und definierten Kontaktpunkt der Tumorzellen mit dem Hirngewebe als möglichen Startpunkt für eine Invasion zu schaffen, wurden die Zellen in ECM eingebettet und ein Tropfen davon an den Außenrand des Koronarschnittes pipettiert. ECM umgibt die Zellen auch im physiologischen Interzellularraum. Die Hauptbestandteile der ECM sind Kollagene, Proteoglykane und Glykoproteine. Im Allgemeinen besteht die Aufgabe der Extrazellulären Matrix darin, dem Gewebe mechanische Stabilität zu verleihen, sowie Proliferation, Migration, Adhäsion und terminale Differenzierung von Zellen zu ermöglichen (Carey et al. 1986). Physiologische Prozesse wie Migration und Proliferation von Zellen können nur 
stattfinden, wenn zwischen den Zellen untereinander und der Matrix ein Kontakt vorhanden ist. Die Zell-zu-Zell und Zell-zu-Matrix Interaktionen werden über die Familie der Zell Adhäsions Moleküle vermittelt, zu der beispielsweise Selektine, Integrine und Cadherine gehören (Mousa 2007). Das ECM-Gel bietet darüber hinaus die Möglichkeit einer drei-dimensionalen Zellkultur. Die Tumorzellen befinden sich damit in einer Interzellulärsubstanz, die für die Tumorzellen eine geeignete Umgebung schafft, in der Migration, Proliferation und Austausch von Signalstoffen zwischen den Zellen gewährleistet sind. Dazu passend konnte die Arbeitsgruppe Ulrich zeigen, dass die Invasion von Gliomzellen durch die Zusammensetzung der ECM beeinflusst wird. Ein erhöhter Anteil an Agarose in der ECM verringert die Invasivität der Tumorzellen (Ulrich et al. 2010). Aus der Master-Arbeit von Martina Podleschny in der Arbeitsgruppe Binder/Pukrop wird erkennbar, wie sich die Einbettung von Tumorzellen in ECM auf Tumorzellen auswirkt. Im Unterschied zur Adhäsion der Zellen an Kunststoffoberflächen von Petrischalen beeinflusst die Einbettung positiv die Beweglichkeit und damit die Invasionsfreudigkeit der Tumorzellen (Podleschny 2006).

Das ECM-Gel weist den weiteren Vorteil auf, dass die Tumorzellen in einen runden Tropfen Gel einbettet werden können. Dieser ECM-Tropfen wird schließlich neben den Hirnschnitt gesetzt. Somit werden die Tumorzellen nicht wahllos über den Schnitt verteilt, sondern befinden sich gebunden in dem Geltropfen in einer eindeutig bestimmten Position zum Hirnschnitt. Der Tumorzelltropfen bildet damit einen definierten Ausgangspunkt der malignen Zellen in der Ko-Kultur mit dem Hirnschnitt. Jede Tumorzelle, die schließlich in dem Hirnschnitt gefunden wird, muss aus diesem ECM-Tropfen heraus und in das Hirngewebe hinein gewandert sein. Diese Annahme gilt allerdings nur unter der Prämisse, dass es nicht zu einer Kontamination mit Tumorzellen auf dem Hirnschnitt kommt.

\subsubsection{Abschirmung des Hirnschnitts beim Platzieren der Tumorzellen}

Trotz der zuvor beschriebenen Verbesserung der Versuchsbedingungen zeigten sich beim Platzieren des Tumortropfens Zellen, die über den Schnitt versprengt wurden. Um die Verschleppung der Tumorzellen zu verhindern, wurde anschließend das Hirngewebe beim Setzen des Gel-Tropfens abgeschirmt. Unter Verwendung eines sterilisierten Deckglases zur Abschirmung, welches mit $45^{\circ}$ Kippung an den Außenrand des Hirnschnittes gehalten wurde, konnte der Gel-Tropfen an dessen Unterkante pipettieret werden. Mit dem Deckglas war gewährleistet, dass initial keine Tumorzellen 
über dem Hirngewebe ausgesetzt wurden. Somit gilt nun die Annahme, dass jede Tumorzelle, die nach 5 Tagen Kultur in dem Hirngewebe gefunden wurde, direkt aus dem Tumorzelltropfen eingewandert sein musste.

\subsubsection{Wie kann residente Mikroglia von eingewanderten Blutmakrophagen unterschieden werden?}

Bis heute gibt es keinen etablierten Marker, der zwischen residenter Mikroglia und eingewanderten Blutmakrophagen zu unterscheiden vermag (Pukrop et al. 2010). Dies ist jedoch von grundlegender Bedeutung, wenn man die Reaktion der Mikroglia auf maligne Zellen untersuchen und gegen mögliche Effekte eingewanderter TAM abgrenzen möchte. Einen Ansatz, die Unterscheidung zwischen Mikroglia und eingewanderten Makrophagen vorzunehmen, lieferte Watters, mit der Messung von CD45-low versus CD45-high exprimierenden CD11b/c positiven Zellen (Watters et al. 2005). Dabei waren Mikroglia und Makrophagen für den Marker CD11b/c beide positiv, wohingegen sie CD45 unterschiedlich exprimierten. Mikroglia zeichnete sich durch CD45-low, CD11b/c-high aus, Makrophagen hingegen durch die Kombination aus CD45-high, CD11b/c-high (Watters et al. 2005). Problematisch ist bei dem Ansatz von Watters allerdings, dass die alleinige Unterscheidung auf Grund des CD45-Markers der Vielzahl von Subpopulationen, die Makrophagen und Mikroglia auszeichnen, nicht gerecht wird. Dieser und auch andere Ansätze hierzu lassen Zweifel aufkommen, ob zum jetzigen Zeitpunkt eine exakte Identifizierung und auch Separierung von Mikroglia und Makrophagen möglich ist.

In dem in dieser Arbeit vorgestellten Ko-Kulturmodell konnte das übliche Problem der fehlenden Unterscheidungsmöglichkeit zwischen Mikroglia und Makrophagen vermieden werden, da in den Hirnschnitten nach erfolgter Präparation keine TAM einwandern konnten. In den Organotypischen Hirnschnitten befanden sich neben den Mikrogliazellen nur noch die perivaskulären Monozyten. Ob diese Monozyten im perivaskulären Raum eine residente Population darstellen, ist augenblicklich Gegenstand wissenschaftlicher Diskussionen. Die Monozyten können leicht das Endothel der Gefäße im Gehirn durchdringen. Sie verbleiben nach erfolgter Penetration allerdings im perivaskulären Raum, auch Virchow-Robin-Raum genannt. Von diesem Virchow-Robin-Raum besteht kein direkter Zugang in das Hirnparenchym. Das Neuropil ist vom Virchow-Robin-Raum abgegrenzt durch die Glia Limitans, bestehend aus einer Basalmembran und den Fußfortsätzen der Astrozyten. Diese 
Barriere können die perivaskulären Monozyten nicht ohne weiteres überwinden und haben somit keinen unmittelbaren Zugang zum Neuropil (Bechmann et. al 2007). Somit darf in dem hier vorliegenden Fall davon ausgegangen werden, dass es sich bei den angefärbten Mikroglia um residente Gliazellen handelt. 


\section{Diskussion der Ergebnisse der Konfokal- und Time- Lapse-Mikroskopie}

\subsection{Interaktionen zwischen Tumorzellen und Mikroglia im Konfokal-Mikroskop}

Die Auswertung der Ko-Kultur erfolgt mittels Konfokal-Mikroskopie. Hierbei können Bilder von übereinanderliegenden Schichten erzeugt werden, sodass eine valide Beurteilung möglich ist, ob die Tumorzellen tatsächlich in den Schnitt eingedrungen sind. Aus den Beobachtungen können eine Reihe von Besonderheiten hergeleitet werden:

\subsubsection{Mikroglia sammelt sich in der Nähe der Tumorzellen}

In der Region, in der der Tumorzell-ECM-Tropfen am Hirnschnitt anliegt, wurde im Verhältnis zum übrigen Schnitt ein sehr viel stärkeres Signal für den mikrogliären Antikörper Alexa 647 detektiert. Offenbar sammeln sich Mikrogliazellen in der Nähe der Tumorzellen und bilden eine wandähnliche Struktur aus kleinen, amöboiden, dichtgepackten Zellen. Diese Beobachtung weist auf das Vorhandensein einer Infiltrations-Zone hin und passt zu den Ergebnissen aus den Untersuchungen an histologischen Schnitten humaner Hirnmetastasen (Pukrop et al. 2010). In der Zone zwischen Hirnmetastase und dem umgebenden intakten Hirngewebe stellt sich eine Akkumulation von aktivierten, nicht ramifizierten Mikrogliazellen dar. In dieser Infiltrationszone finden sich Kohorten von Tumorzellen. In Nachbarschaft zu diesen Tumorzellen konnten mittels KI-M1P-Färbung Mikrogliazellen nachgewiesen werden (Pukrop et al. 2010). Für die Existenz einer solchen Infiltrations-Zone sprach sich kürzlich auch Baumert aus. Sie stellte bei der Autopsie von Patienten mit Hirnmetastasen in $63 \%$ der Fälle fest, dass ein infiltratives Wachstum von Tumorzellen über den Rand der Metastase hinaus stattfindet (Baumert et al. 2006).

\subsubsection{Mikroglia in Kontakt mit Tumorzellen zeigt eine typische Morphologie.}

In den Kontrollen, an denen am Koronarschnittrand ein ECM-Tropfen ohne Tumorzellen positioniert wurde, zeigt sich keine Akkumulation von Mikroglia. Hier findet 
sich ein homogenes Verteilungsmuster ramifizierter Mikrogliazellen. Im Unterschied dazu konnte festgestellt werden, dass Mikroglia, die in Kontakt mit den Tumorzellen kommt, eine typische Morphologie aufweist. Mit einem Gradient auf die Tumorzellen hin, lassen sich Ansammlungen von amöboiden, runden, dicht beieinanderstehenden Mikrogliazellen erkennen. Ferner konnte eine dritte Erscheinungsform ausgemacht werden. Mikroglia, die in direkter Nachbarschaft zu den Tumorzellen steht, formt dicke „Arme“ in synapsenähnlichen Formationen aus. Einige Mikrogliazellen fallen dabei auf, wie sie eine Tumorzelle mit ihren synapsenartigen Fortsätzen umschlossen halten.

Es ist bekannt, dass Mikroglia auf einen pathologischen Reiz mit Proliferation, verändertem Immunphaenotyp und einer veränderten Morphologie reagiert. Basierend auf seinen Silberkarbonat-Färbungen beschrieb del Rio Hortega als erster die unterschiedlichen Erscheinungsformen von Mikrogliazellen und teilte sie in drei Gruppen ein: amöboide, ramifizierte und intermediäre Formen von Mikroglia (Del Rio Hortega 1932). Spätere Studien klassifizierten Mikroglia aufgrund ihres Aktivitätzustandes in ruhende, ramifizierte, aktivierte und amöboide, phagozytierende Mikroglia (Streit et al. 1988). In dieser Arbeit konnte in Kontakt mit Tumorzellen ein Wall aus amöboiden Mikrogliazellen und daneben eine Form mit synapsenartigen Ausläufern beobachtet werden. Ob diese Befunde nun nach Streit in amöboid, phagozytierend oder in eine intermediäre Form einzuteilen sind, bleibt zunächst unklar. Es lässt sich die Hypothese aufstellen, dass es sich bei den Mikrogliazellen mit den synapsenartigen Ausläufern um einen bisher noch nicht beschriebenen, unbekannten Subtyp handelt, den die Mikroglia in der Kommunikation mit den Tumorzellen einnimmt. Dafür spricht die Tatsache, dass beispielsweise M2-Makrophagen eine Vielzahl von Aktivierungszuständen kennen (Mantovani et al. 2004). Möglicherweise reagiert auch Mikroglia sehr divers und spezifisch und kann in Kontakt mit malignen Zellen einen tumorspezifischen Subtyp einnehmen. Als Gegenargument zu dieser Hypothese lässt sich anführen, dass es sich bei Mikroglia in Kontakt mit Tumorzellen analog der Einteilung von Streit auch nur um eine Übergangsform von ramifizierten zu amöboiden Mikroglia handelt. Die Klärung dieser Hypothesen bleibt zukünftigen Studien vorbehalten.

\subsubsection{Tumorzellen invadieren in den Hirnschnitt}

Nach 5 Tagen der Ko-Kultur können Tumorzellen nachgewiesen werden, die aus dem ECM-Tropfen heraus in den Hirnschnitt eingewandert sind. Dabei lassen sich einzelne Tumorzellen finden, aber auch Zellen, die scheinbar in einem Zellverband gewandert 
sind. Weiterhin können Kolonien von Tumorzellen entdeckt werden, die sich zu einem frühen "Metastasenkern“ formieren. Neben invadierten Tumorzellen konnten meist in direkter Umgebung Mikrogliazellen beobachtet werden. Dies passt zu den oben beschriebenen Beobachtungen in humanen Hirnmetastasen (Pukrop et al. 2010) und unterstreicht, dass das verwendete ex-vivo-Kolonisationsmodell der in-vivo-Situation sehr nahe kommt.

\subsubsection{Mikroglia invadiert in den Tumorzell-ECM-Tropfen}

Dass die Tumorzellen im Laufe der Kultur in den Hirnschnitt einwandern können, war bereits vor Beginn dieser Arbeit ein erwartetes Ergebnis. Erstaunlich ist jedoch die Beobachtung, dass Mikroglia auch umgekehrt in den Tumorzell-ECM-Tropfen hinein migriert. Diese Mikroglia weist in der Mehrzahl der Fälle einen amöboiden Zelltyp auf. Es lässt sich vermuten, dass die Tumorzellen einen Signalstoff produzieren, der Mikroglia anlockt. Zudem ist es denkbar, dass Mikroglia den ECM-Tropfen und die Tumorzellen als fremd erkennt und auf diesen in ihrer Funktion als Zellen des angeborenen Immunsystems zuwandert. In den Kontrollen mit einem leeren ECMGeltropfen ohne Tumorzellen ist jedoch keine Mikroglia eingewandert. Dies unterstreicht die Vermutung, dass die Tumorzellen chemotaktische Faktoren sezernieren und nicht der ECM-Tropfen allein die Mikroglia anlockt. Diese Annahme wird durch die Arbeit von Kielian, Rooijen und Hickey untermauert. Sie identifizierten den chemotaktischen Faktor MCP-1, die von CNS-1-Zellen einer Glioblastomzelllinie produziert wird und so zur Rekrutierung von Makrophagen in das Tumorgewebe beiträgt (Kielian et al. 2002). Als weiterer Hinweis auf diese These konnte gezeigt werden, dass die Produktion von VEGF beim Mamma-Karzinom Makrophagen anzieht und damit einen wichtigen Faktor für den Aufbau eines Tumormilieus mit TAM darstellt (Leek et al. 1996). Das beobachtete Verhalten der Mikrogliazellen führt zu der Annahme, dass Mikroglia ähnlich den Makrophagen durch die Tumorzellen rekrutiert werden.

\subsubsection{Mikroglia bahnt den Tumorzellen den Weg in das Hirngewebe}

Zwischen dem ECM-Tropfen und dem Hirngewebe formieren sich die Mikrogliazellen am Rand des Schnittes zu langen, spindelförmigen, weite Strecken überspannenden Ausläufern. Diese Ausläufer formen zusammen eine Art Straße, die ähnlich wie eine Brücke zwischen ECM-Tropfen und dem Hirngewebe fungiert. Um die Mikroglia herum und in diese Struktur eingebettet sind Tumorzellen zu detektieren. Anscheinend wandern die Tumorzellen entlang dieser „Mikrogliastraßen“ in den Schnitt ein. Auch die 
bereits invadierten Tumorzellen sind stets von Mikroglia umgeben. Dabei lassen sich Mikroglia auch an der Spitze von im Zellverband wandernden Tumorzellen beobachten, gewissermaßen als führende Zellen in der Infiltrations-Zone, gleichsam einer „Speer-Spitze“, die den weiteren Weg der Tumorzellen in das Gewebe bereitet.

\subsection{Tumorzell-Mikroglia-Interaktionen in der Time-Lapse- Mikroskopie - Der „tödliche Kuss“ der Mikroglia}

Die genannten Beobachtungen in der Konfokal-Mikroskopie werden im Time-LapseMikroskop bestätigt. Bei der Analyse über mehrere Tage ist Folgendes zu beobachten: Eine Vielzahl kleiner Zellen wandert aus dem Schnitt heraus und auf die Tumorzellen zu. Dabei handelt es sich um kleine Zellen, die ihre runde Form in eine verzweigte ändern und mit weiteren Zellen dieser Art ein lange "Zellstraße“ bilden, die brückenähnlich vom Hirnschnitt in den ECM-Tropfen hineinragt. Entlang dieser Struktur lagern sich mit EGFP markierte Tumorzellen an und wandern in das Hirngewebe hinein. Im Übrigen konnte beobachtet werden, dass einzelne kleine Zellen sich auf die Tumorzellen zubewegen, sich innen anlagern, sie quasi „küssen“ um alsdann Zellausläufer auszubilden und mit diesen „Armen“ schließlich die Tumorzellen umschließen. Anschließend werden die so umfassten malignen Zellen in den Hirnschnitt hineingezogen. Es lässt sich vermuten, dass es sich bei den kleinen, auf die Tumorzellen zuwandernden Zellen um Mikroglia handelt, was in späteren Versuchen bestätigt werden konnte (Pukrop et al. 2010).

Zusammenfassend zeigen die Ergebnisse der Konfokalmikroskopie und des LiveImaging eindeutig, dass Mikroglia die Invasion der Tumorzellen aktiv unterstützt. Mikroglia in der Infiltrationszone fungiert als Transporter für die malignen Zellen auf dem Weg in das Hirngewebe. Den invadierten Tumorzellen vorausgehend finden sich stets Mikrogliazellen an der Spitze der infiltrierenden Zellkohorten. Dies zeigt, dass Mikroglia zum einen als aktiver Transporter für die Tumorzellen dient und darüber hinaus den weiteren Weg ins Gewebe für die malignen Zellen bereitet. Es ist somit gelungen nachzuweisen, dass Mikroglia als residente Makrophagen ähnlich den TAM eine essentielle Rolle bei der Invasion und Kolonisation der Tumorzellen einnimmt. Die einleitend gestellte Frage, „Existiert Tumor-assoziierte Mikroglia?“ kann anhand der Beobachtungen dieser vorgelegten Arbeit mit ja beantwortet werden. Von den TAM wissen wir, dass sie potenziell die Fähigkeit aufweisen, Wachstums- und angiogenetische Faktoren zu produzieren sowie proteolytische Enzyme freizusetzen, 
die die extrazelluläre Martix (ECM) degradieren. TAM besitzen Werkzeuge, die das Tumorzellwachstum, die Neubildung von Gefäßen sowie die Invasion und Metastasierung fördern (Balkwill und Matovani 2001). In dieser Arbeit konnten Mikrogliazellen an der Spitze der Infiltrationszone nachgewiesen werden. Weiterhin bildet Mikroglia mit ihren Armen „Führungsschienen“ für die Tumorzellen aus. Beides erleichtert den Tumorzellen den Weg in das Hirngewebe. Noch unklar bleibt, über welche Mechanismen die Mikroglia im Unterschied zu den TAM agiert. Die Klärung dieser Frage, über welche Mechanismen die beschriebenen Prozesse der Mikrogliaaktion gesteuert werden, bleibt künftigen Arbeiten vorbehalten.

Bei den TAM kann man grundsätzlich zwei Funktionsprogramme unterscheiden. In Abhängigkeit von den Signalen des umgebenden Kompartimentes entwickeln sich die Makrophagen in den Subtyp M1 oder M2. Der M1-Typ repräsentiert dabei die Makrophage der „klassischen“ Entzündungsreaktion. Demgegenüber steht der Typ M2 für die Vielzahl der alternativen Aktivierungsmöglichkeiten (Mantovani et al. 2004). In malignen Prozessen sind überwiegend TAM vom M2-Typ beteiligt (Balkwill et al. 2005).

Aus den Unterschieden in der Mikroglia-Morphologie in unserem Modell lässt sich ableiten, dass bei Mikroglia wie bei den TAM ebenfalls unterschiedliche, auf den jeweiligen Reiz spezifische Aktivitätszustände existieren. Ob diese Aktivitätszustände einer vergleichbaren Einteilung in einen M1- und M2-Typ folgen, wobei letzterer die Invasion der Tumorzellen fördert, bleibt zu klären. Ebenso bleibt es zukünftigen Studien vorbehalten zu analysieren, ob der Wnt-Signalweg bei der Arbeitsweise der Mikroglia eine ähnliche Rolle spielt wie bei den TAM. Diese und weitere Thesen gilt es zu klären, um die Beobachtungen, die mit dem in dieser Arbeit vorgestellten KoKulturmodell festgestellt wurden, vollständig zu verstehen. Mit dieser Arbeit konnte jedoch bereits der Nachweis erbracht werden, dass Mikroglia bei Invasion und Metastasierung epithelialer Tumore eine entscheidende Schlüsselrolle einnehmen.

Bisher wurde angenommen, dass Tumorzellen für die Invasion notwendigerweise einer Ausstattung mit mesenchymalen Merkmalen bedürfen. Dabei verlieren die Tumorzellen inren epithelialen Charakter, was durch den Verlust von E-Cadherin und Zytokeratin deutlich wird (Yang und Weinberg 2008). Dieser Wechsel wird auch EpithelialeMesenchymale-Transition (EMT) genannt. Epitheliale Zellen besitzen eine apikalebasale Polarität zu einer Basalmembran. Untereinander bilden die Epithelzellen laterale Zell-zu-Zell Kontakte über Adhäsionsmoleküle aus (Yap et al. 1997). Unter 
normalen Umständen sichert die Verankerung in der Basalmembran, dass die epithelialen Zellen ausschließlich lateral migrieren können. Somit ist sichergestellt, dass sie ihre Position in dem Epithel beibehalten und nicht in die umgebende ECM eindringen können (Yang und Weinberg 2008). Im Rahmen dieser Arbeit konnte jedoch beobachtet werden, dass Tumorzellen im Verband in den Hirnschnitt wandern, wobei sie an der Invasionsfront von Mikroglia geleitet werden. Die Mamma-Karzinom Zellen in der hier vorgestellten Ko-Kultur sind epithelialen Ursprungs. Mikrogliazellen stellen mesenchymale Zellen dar. Hieraus kann geschlussfolgert werden, dass die epithelialen Tumorzellen die mesenchymalen Eigenschaften der Mikroglia an der Spitze der Invasionsfront benutzen, um in das Gewebe vorzudringen.

\subsection{Chancen und Grenzen für weitere Untersuchungen mit der entwickelten Ko-Kultur}

Die exemplarische Anwendung der Methode führte zu einer Reihe offener Fragen, die in dieser Arbeit nicht abschließend gelöst werden konnten. Jedoch bieten die hier erhobenen Beobachtungen wertvolle Anregungen für weitere Studien. Die Chancen und Grenzen der weiterentwickelten Organotypischen Hirnschnittkultur als Ko-Kultur sollen nachfolgend dargelegt werden.

Die Viabilität der Organotypischen Hirnschnittkultur konnte im Rahmen dieser Arbeit nicht sicher überprüft werden. Zwar wurden die Schnitte täglich unter dem Auflichtmikroskop auf ihre Morphologie hin kontrolliert. Dabei fielen Schnitte, die im Verlauf zugrunde gingen, bereits nach den ersten Tagen in Kultur durch ein „ungesundes“ Äußeres auf. Die weniger vitalen Hirnschnitte zeichneten sich durch eine Verplumpung der Rindenfurchung, durch eine ödematöse Schwellung des Gewebes sowie durch das Auftreten lytischer Areale aus. Für die Ko-Kultur wurden nur Hirnschnitte eingesetzt, die intakt waren und gesund aussahen. Um tote Zellen besser erkennen zu können, wurde eine Färbung mit Propidium-Jodid durchgeführt. Propidium-Jodid hat allerdings den Nachteil, dass es nicht durch alle Schichten des $350 \mu \mathrm{m}$ dicken Schnittes hindurch diffundiert. Somit ergab sich lediglich eine Kernfärbung mit Propidium-Jodid in der obersten Zellschicht des Schnittes. Hierbei ist jedoch zu bedenken, dass die obersten Schichten durch den Schneidevorgang einer stärkeren Manipulation und unter Umständen auch einer größeren Schädigung unterliegen als in tieferen Zellschichten. Dadurch waren die Ergebnisse der Kernfärbung nicht eindeutig, so dass dieser Ansatz verworfen wurde. Ein weiterer 
Viabilitätsessay wurde im Rahmen dieser Arbeit nicht durchgeführt. Eine Überprüfung der Vitalität der Schnitte zum weiteren wissenschaftlichen Arbeiten mit dieser Methode erfolgte in der Zwischenzeit mit Hilfe von MTT-Essays (Pukrop et al. 2010).

Unter dem Konfokalmikroskop war beobachtbar, dass die Tumorzellen in den Hirnschnitt einwandern. Für den Versuchsansatz wurde eine definierte Menge Tumorzellen verwendet, nämlich $1 \times 10^{5}$ Zellen $/ \mathrm{ml}$. Allerdings erfolgte keine Quantifizierung der Tumorzellinvasion. So war es im Rahmen dieser Arbeit nur schwer möglich, einen Vergleich von zwei Hirnschnitten vorzunehmen und eine Aussage über die Menge invadierter Zellen zu treffen. Um jedoch die Tumorzellinvasion zweier Schnitte besser vergleichbar zu machen, sollte eine Möglichkeit geschaffen werden, die Invasion zu quantifizieren. Denkbar ist hierfür beispielsweise eine semiquantitative Einteilung, die drei Abstufungen beinhaltet, mit einer hohen, einer mittleren und einer niedrigen Tumorzelldichte. Die Praktikabilität solch einer semiquantitativen Einteilung hat sich im weiteren Verlauf der Forschungsarbeiten ebenfalls bestätigt (Pukrop et al. 2010).

In der in dieser Arbeit verwendeten Ko-Kultur wird eine humane Mamma-KarzinomZelllinie eingesetzt. Der Hirnschnitt ist jedoch murinen Ursprungs. Unklar ist hier, welchen Effekt die unterschiedlichen Spezies von Tumorzellinie und Gewebe auf die Untersuchung der Zellinteraktionen und der Metastasierungsvorgänge ausüben. Es konnte beispielsweise gezeigt werden, dass humane Glioblastomzellen auf einem Rattenhirn eine ähnlich starke Invasion in das Gewebe zeigen wie eine RattenGlioblastomzelllinie (Matsumura et al. 2000). Dennoch wäre es hier vorteilhaft, das KoKulturmodell mit einer murinen Tumorzellinie zu wiederholen. Diese Versuche wurden nach Abschluss der Arbeit auch durchgeführt und zeigen, dass sich die Invasion und Kolonisation der Tumorzellen ähnlich verhalten, gleich ob humaner oder muriner Herkunft (Pukrop et al. 2010). 


\section{$7 \quad$ Abgeleitete Thesen zur Tumorinvasion}

\subsection{Mikroglia im Zusammenhang mit dem Wnt-5a-Signalweg}

Im Rahmen dieser Arbeit wurde nicht überprüft, wie sich die Tumorzellinvasion verhält, wenn die Mikroglia in ihrer Aktivität gehemmt wird. Vor einiger Zeit konnten Pukrop et al. zeigen, dass ein invasionsfördernder Effekt von Makrophagen vollständig durch die Gabe von DKK-1, einem Antagonisten des Wnt5-a Signalweges, aufgehoben werden kann (Pukrop et al. 2006). Es stellt sich die Frage, was geschieht, wenn DKK-1 in die Organoptypische Hirnschnittkultur eingebracht wird. Es ist zu vermuten, dass es bei einer Inhibition der Aktivität der Mikroglia unter Umständen auch zu einer Hemmung der Invasion der Tumorzellen kommt. Die Göttinger Arbeitsgruppe stellte fest, dass es in den Mikrogliazellen, anders als bei TAM, zu keiner Hochregulation von Wnt-5a kommt und Mikroglia nur partiell durch DKK-1 inhibierbar ist. Allerdings konnte in der Boyden-Chamber eine Ko-Kultur ohne direkten Zell-zu-Zell Kontakt sowie auch in der Hirnschnittkultur die Invasion der Tumorzellen durch die Gabe von DKK-2 gehemmt werden (Pukrop et al. 2010). DKK-2 gehört ebenfalls wie DKK-1 zu den Antagonisten des Wnt-Signalweges. Dabei wird sowohl von DKK-1 und DKK-2 vor allem der Wnt/ $\beta$ Catenin Weg über die Bindung an die Ko-Rezeptoren LRP5/6 inhibiert (Niehrs 2006). DKK-1 und DKK-2 unterscheiden sich jedoch in ihrer Wirkung durch den molekularen Kontext, in dem sie agieren (Brott und Sokol 2002). Dies erklärt unter Umständen auch die ungleichen Effekte von DKK-1 und DKK-2 auf Makrophagen und Mikroglia. Ein weiterer Unterschied zwischen Mikroglia und TAM konnte im Verlauf bereits aufgedeckt werden. Anders als bei den TAM fehlt bei den Mikrogliazellen die Ausprägung eines M2-Zytokinprofils. Mikroglia übt ihren proinvasiven Effekt auf die Tumorzellen nicht über die Hochregulation von MMPs und TNF $\alpha$ aus (Pukrop et al. 2010). Jedoch erfolgt bei einer Stimulation mit LPS eine Veränderung der Mikroglia hin zum M1-Zytokinprofil. Weiter konnte festgestellt werden, dass Mikroglia mit einem M1 Profil nicht länger die Invasion von Tumorzellen unterstützt (Pukrop et al. 2010). Offenbar besitzen Mikroglia und TAM ähnlich invasionsfördernde Effekte auf Tumorzellen. Allerdings scheinen sie diese Reaktion über vollkommen unterschiedliche Mechanismen auszuüben. Für ein tieferes Verständnis dieser Unterschiede wäre es sicherlich interessant, die Effekte über Wnt-Signalwege und auch Zytokinprofile weiter zu analysieren. 


\subsection{Inhibition der Mikroglia durch Bisphosphonate}

Eine nächste Überlegung wäre es, einen Hirnschnitt zu verwenden, in dem keine Mikrogliazellen enthalten sind. Eine Depletierung der Mikroglia aus dem Schnitt gelingt mit der Zugabe von Clodronat. Clodronat gehört zur Gruppe der Bisphosphonate. Bisphosphonate inhibieren generell Makrophagen und werden im klinischen Alltag zur Hemmung von Osteoklasten, den residenten Makrophagen des Knochens, eingesetzt. Die „Austrian Breast and Colorectal Cancer Study Group trial 12“ analysierte in einer Studie die adjuvante Therapie mit dem Bisphosphonat Zoledronat bei postmenopausalen Patientinnen mit Östrogen-Rezeptor positiven Mamma-Karzinom. Es zeigte sich, dass die Gabe von Zolderonat das rezidivfreie Intervall verlängerte, überraschenderweise nicht nur durch Verhinderung von Knochen- sondern auch von anderen Metastasen (Gnant et al. 2009). Neben der postulierten direkten antitumorösen Wirkung von Zoledronat spricht dies auch für eine indirekte antimetastatische Wirkung über die Hemmung residenter Makrophagen. Passend dazu konnte im Fall hirneigener Tumore für Gliomzellen gezeigt werden, dass die Vorbehandlung der Hirnschnitte mit Bisphosphonaten mit einer signifikant geringeren Invasion der Tumorzellen einhergeht (Markovic et al. 2005). Hierbei wurden die Hirnschnitte mit liposomalem Clodronat behandelt und so selektiv die Mikroglia depletiert. Weiterhin konnte Markovic demonstrieren, dass die Invasivität der Tumorzellen erneut gesteigert wurde, wenn die Gliomzellen zusammen mit externen Mikroglia in einen zuvor depletierten Hirnschnitt reinjiziert wurden (Markovic et al. 2005). Dies wirft folglich die Frage auf, wie eine Depletion von Mikroglia sich auf die Invasivität einer epithelialen Tumorzellinie auswirkt. Weiterführend wäre der Einsatz von Bisphosphonaten bei Hirnmetastasen in vivo interessant, beispielsweise bei Patientinnen mit metastasiertem MammaKarzinom. Allerdings müssten für diesen pharmakologischen Einsatz Bisphosphonate so modifiziert werden, dass sie in der Lage wären, die Bluthirnschranke zu überwinden.

\subsection{Ko-Kultur des Organotypischen Hirnschnittes mit einer benignen Zelllinie}

Innerhalb dieser Arbeit wurde der ECM-Gel-Tropfen stets mit einer Tumorzelle gefüllt oder als Leerkontrolle eingesetzt. Was geschieht, wenn eine benigne Zellinie in das Gel eingebettet und neben dem Hirnschnitt platziert wird? Wie verhält sich die Mikroglia dann? Erste Hinweise aus der Göttinger Arbeitsgruppe deuten darauf hin, dass sich Mikroglia gegenüber benigen fremden Zellen in Gänze anders verhält. Während Tumorzellen den Kontakt mit den Mikroglia überleben und mit ihrer Hilfe in 
das Hirngewebe invadieren, initiiert die Mikroglia den Zelltod der benignen Zellen. Bisher sind diese gänzlich konträren Aktivitäten der Mikroglia noch nicht vollständig verstanden. Die faszinierende Heterogenität und Plastizität der residenten Makrophagen des Gehirns sind hoffentlich Gegenstand zukünftiger Forschung. 


\section{$8 \quad$ Zusammenfassung}

Übergeordnetes Ziel dieser Arbeit war es, einen Beitrag zum Verständnis zerebraler Metastasierung von Mamma-Karzinomen zu leisten, wobei insbesondere der Einfluss der Mikrogliazellen als ortsständige Makrophagen des Gehirns auf diesen Prozess im Fokus der Betrachtung steht. Hierzu sollten die Wechselbeziehungen zwischen Tumorzellen, Mikroglia und dem Tumorstroma in einem ex-vivo-Modellsystem beobachtbar gemacht werden.

Im Rahmen dieser Arbeit konnte die Methode der Organotypischen Hirnschnittkultur mit eigenen Änderungen als Ko-Kultur erfolgreich etabliert werden. Es konnte am Beispiel humaner Mamma-Karzinom-Zellen gezeigt werden, dass die Methode geeignet ist, die Tumorinvasion zu beobachten. Im Rahmen dieser exemplarischen Anwendung konnte einerseits die Vermutung bestätigt werden, dass Mikroglia als ortsständige Makrophagen die Tumorinvasion ebenso effektiv fördert wie TAM. Zudem konnten überraschenderweise Effekte festgestellt werden, dass Mikrogliazellen aktiv die Tumorinvasion begünstigen, indem sie in die extrazelluläre Matrix migrieren, von dort die Tumorzellen abholen und ihnen den Weg ins Hirngewebe weisen.

Damit ist die etablierte Methode offensichtlich geeignet, eine Vielzahl weiterer Theorien zu untersuchen, die sich in diesem Zusammenhang stellen, zum Beispiel könnten folgende Hypothesen überprüft werden:

- An der Grenze zwischen den Tumorzellen und dem Hirngewebe befindet sich eine Infiltrationszone mit Mikrogliazellen.

- Die Tumorzellen rekrutieren Mikroglia durch die Sekretion chemotaktischer Faktoren und locken sie über diese Signalstoffe an.

- Mikroglia nimmt in der Kommunikation mit Tumorzellen einen bisher unbekannten Subtyp ein.

- Mikroglia bewirkt als Führer der Tumorzellen, dass die Tumorzellen die BlutHirnschranke überwinden können.

Die Klärung dieser Hypothesen bleibt der Arbeit zukünftiger Forschung vorbehalten. 
Darüber hinaus wird auch noch Potenzial gesehen, wie die Methode selbst weiter verbessert und in ihrer Aussagekraft noch ausgereifter abgesichert werden kann. Hierzu wird besonders auf folgende Punkte verwiesen:

- die Verifizierung der Vitabilität der Organotypischen Hirnschnitte

- die Quantifizierung der Tumorzellinvasion

- die Durchführung der Ko-Kultur mit einer Spezies-äquivalenten KarzinomZelllinie muriner Herkunft.

Ein Teil dieser Fragen ist inzwischen von der Göttinger Gruppe um Binder/Pukrop bereits untersucht worden. Dabei konnte immer wieder die Effektivität und Aussagekraft der hier entwickelten Methode bestätigt werden. Ein weiteres Arbeiten mit dieser Methode ist also sinnvoll und wünschenswert. Im weiteren Verlauf könnte das Studium der Interaktion von Tumorzellen und Mikroglia wichtige klinische Implikationen hervorbringen. So könnten sich zum Beispiel aus den Erkenntnissen des prometastatischen und proinvasiven Einflusses der Mikroglia Empfehlungen für die Hirnchirurgie ergeben. Metastasen im ZNS sind von einer Gliazellnarbe umgeben, die bei der operativen Sanierung bisher in situ belassen wird. Die Beobachtungen von Tumorzellen in dieser "Narbe“ legen jedoch eine Resektion dieses Gliazellmantels nahe und lassen vermuten, dass das Auftreten von Rezidiven dadurch reduziert werden kann. 


\section{$9 \quad$ Literaturverzeichnis}

Allavena P, Sica A, Garlanda C, Mantovani A (2008): The Yin-Yang of tumorassociated macrophages in neoplastic progression and immune surveillance. Immunol $\operatorname{Rev} \underline{222}, 155-61$

Balkwill F, Mantovani A (2001): Inflammation and cancer: back to Virchow? Lancet 357, 539-45.

Balkwill F, Charles K, Mantovani A (2005): Smoldering and polarized inflammation in the initiation and promotion of malignant disease. Cancer Cell $\underline{7}, 211-217$.

Barnholtz-Sloan JS, Sloan AE, Davis FG, Vigneau FD, Lai P, Sawaya RE (2004): Incidence proportions of brain metastases in patients diagnosed (1973 to 2001) in the Metropolitan Detroit Cancer Surveillance System. J Clin Oncol 22, 2865-2872

Baumert BG, Rutten I, Dehing-Oberije C, Twijnstra A, Dirx M, Debougnoux-Huppertz R, Lambin P, Kubat B (2006): A pathology-based substrate for target definition in radiosurgery of brain metastases. Int J Radiat Oncol Biol Phys $\underline{66}, 187-194$

Bechmann I (2005): Failed central nervous system regeneration: a downside of immune privilege? Neuromol Med $\underline{7}, 217-228$

Bechmann I, Nitsch R: Interaction of glial cells with monocytes; Neuroglia, hrsg. Kettenmann H, Ramson BR, Oxford University Press, Oxford 2004

Bechmann I, Rappert A, Priller J, Nitsch R: The Microlial Component; in: Blood-Brain Interfaces: From Ontogeny to Artificial Barriers. hrsg. v. Dermietzel R, Spray DC, Nedergaard M, Wiley-VCH Verlag GmbH \& Co. KGaA, Weinheim 2006, 169-188

Bechmann I, Galea I, Perry VH (2007): What is the blood-brain barrier (not)? Trends Immunol 28, 5-11 
Bessis A, Béchade C, Bernard D, Roumier A (2007): Microglial control of neuronal death and synaptic properties. Glia $\underline{55}, 233-238$

Bettinger I, Thanos S, Paulus W (2002): Microglia promote glioma migration. Acta Neuropathol $\underline{103}, 351-355$

Biswas SK, Sica A, Lewis CE (2008): Plasticity of macrophage function during tumor progression: regulation by distinct molecular mechanisms. J Immunol 180, 2011-2017

Brana C, Biggs TE, Mann DA, Sundstrom LE (1999): A macrophage hippocampal slice co-culutre system: application to the study of HIV-induced brain damage. J Neurosci Methods $\underline{90}, 7-11$

Brott BK, Sokol SY (2002): Regulation of Wnt / LRP Signaling by Distinct Domains of Dickkopf Proteins. Mol Cell Biol $\underline{22}, 6100-6110$

Carey DJ, Todd MS, Rafferty CM (1986): Schwann cell myelination: induction by exogenous basement membrane-like extracellular matrix. J Cell Biol 102, 2254-2263

Chan AT, Giovannucci EL, Meyerhardt JA, Schernhammer ES, Wu K, Fuchs CS (2008): Aspirin dose and duration of use and risk of colorectal cancer in men. Gastroenterology 134, 21-28

Coltman BW, Ide CF (1996): Temporal characterization of microglia, IL-1 beta-like immunoreactivity and astrocytes in the dentate gyrus of hippocampal organotypic slice cultures. Int J Dev Neurosci 14, 707-719

Condeelis J, Pollard JW (2006): Macrophages: obligate partners for tumor cell migration, invasion, and metastasis. Cell $\underline{124}, 263-266$.

Coussens LM, Werb Z (2001): Inflammatory cells and cancer: think different! J Exp Med 193, F23-F26.

Coussens LM, Werb Z (2002): Inflammation and cancer. Nature $\underline{420}, 860-867$. 
Czapiga M, Colton CA (1999): Function of microglia in organotypic slice cultures. J Neurosci Res $\underline{15}$, 644-651

Dehghani F, Conrad A, Kohl A, Korf HW, Hailer NP (2004): Clodronate inhibits the secretion of proinflammatory cytokines and $\mathrm{NO}$ by isolated microglial cells and reduces the number of proliferating glial cells in excitotoxically injured organotypic hippocampal slice cultures. Exp Neurol 189, 241-251

Del Rio-Hortega P: Microglia; in: Cytology and Cellular Pathology of the Nervous System, hrsg. v. W Penfield, Hoeber, New York 1932, 481-534

DeNardo DG, Johansson M, Coussens LM (2008): Immune cells as mediators of solid tumor metastasis. Cancer Metastasis Rev $\underline{27}, 11-18$

De Simoni A, My Yu L (2006): Preparation of organotypic hippocampal slice cultures: interface method. Nat Protoc $\underline{1}, 1439-1445$

Eyüpoglu IY, Bechmann I, Nitsch R (2003): Modification of microglia function protects from lesion induced neuronal alterations and promotes sprouting in the hippocampus. FASEB J $\underline{17}, 1110-1111$

Färber K, Synowitz M, Zahn G, Vossmeyer D, Stragies R, van Rooijen N, Kettenmann H (2008): An alpha5beta1 integrin inhibitor attenuates glioma growth. Mol Cell Neurosci $\underline{39}, 579-85$

Fitzgerald DP, Palmieri D, Hua E, Hargrave E, Herring JM, Qian Y, Vega-Valle E, Weil RJ, Stark AM, Vortmeyer AO, Steeg PS (2008): Reactive glia are recruited by highly proliferative brain metastases of breast cancer and promote tumor cell colonization. Clin Exp Metastasis 25, 799-810

Flossmann E, Rothwell PM (2007): Effect of aspirin on long-term risk of colorectal cancer: consistent evidence from randomised and observational studies. Lancet $\underline{369}$, 1603-1613

Foskas E, Engenhart-Cabillic R, Daniilidis K, Rose F, An HX (2007): Metastasis: The seed and soil theory gains identity. Cancer Metastasis Rev 26, 705-715 
Friedl P, Gilmour D (2009): Collective cell migration in morphogenesis, regeneration and cancer. Nature Rev Mol Cell Biol $\underline{10}, 445-457$

Gähwiler BH, Capogna M, Debanne D, McKinney R, Thompson SM (1997): Organotypic slice cultures: a technique has come of age. Trends Neurosci $\underline{20}, 471-477$

Gall C, Rose G, Lynch G (1979): Proliferative and migratory activity of glial cells in the partially deafferented hippocampus. J Comp Neurol 183, 539-549

Garlaneau H, Villenueve J, Gowing G, Julien JP, Vallieres L (2007): Increased glioma growth in mice depleted of macrophages. Cancer Metastasis Res $\underline{67}, 8874-8881$

Ginhoux F, Greter M, Leboeuf M, Nandi S, See P, Grokhan S, Mehur MF, Conway SJ, Ng LG, Stanley ER, Samokhvalov IM, Merad M (2010): Fate mapping analysis reveals that adult microglia derive from primitive macrophages. Science $\underline{330}, 841-845$

Giraudo E, Inoue M, Hanahan D (2004): An amino bisphosphonate targets MMP-9expressing macrophages and angiogenesis to impair cervical carcinogenesis. $\mathrm{J}$ Clin Invest $\underline{114}, 623-633$

Giulian D (1993): Reactive glia as rivals in regulating neuronal survival. Glia. $\underline{7}, 102-10$

Giulian D, Chen J, Ingeman JE, George JK, Noponen M (1989): The role of mononuclear phagocytes in wound healing after traumatic injury to adult mammalian brain. J Neurosci $\underline{9}$, 4416-4429

Gloor SM, Wachtel M, Bolliger MF, Ishihara H, Landmann R, Frei K (2001): Molecular and cellular permability control at the blood-brain barrier. Brain Res Brain Res Rev $\underline{36}$, 258-264

Gnant M, Mlineritsch B, Schippinger W, Luschin-Ebengreuth G, Postlberger S, Menzel C, Jakesz R, Seifert M, Hubalek M, Bjelic-Radisic V, Samonigg H, Tausch C, Eidtmann H, Steger G, Kwasny W, Dubsky P, Fridrik M, Fitzal F, Stierer M, Rucklinger E, Greil R, Marth C (2009): Endocrine therapy plus zoledronic acid in premenopausal breast cancer. N Engl J Med $\underline{360}, 679-691$ 
Graeber MB, Streit WJ (2010): Microglia: biology and pathology. Acta Neuropathol $\underline{119}$, 89-105

Hagemann T, Robinson SC, Schulz M, Trumper L, Balkwill FR, Binder C (2004): Enhanced invasiveness of breast cancer cell lines upon co-cultivation with macrophages is due to TNF-alpha dependent up-regulation of matrix metalloproteases. Carcinogenesis $\underline{25}, 1543-1549$

Hagemann T, Wilson J, Kulbe H, Li NF, Leinster D, Charles K, Klemm F, Pukrop T, Binder C, Balkwill $F$ (2005): Macrophages induce invasiveness of epithelial cancer cells via NFk-B and JNK. J Immunol 175, 1197 - 1205

Hagemann T, Lawrence T, McNeish I, Charles KA, Kulbe H, Thompson RG, Robinson SC, Balkwill FR (2008): "Re-educating" tumor-associated macrophages by targeting NF-kappaB. J Exp Med 205, 1261-1268

Halin S, Rudolfsson SH, Van Rooijen Nm Bergh A (2009): Extratumoral macrophages promote tumor and vascular growth in an orthotopic rat prostate tumor model. Neoplasia 11, 177-186

Hanahan D, Weinberg RA (2011): Hallmarks of Cancer: The Next Generation. Cell 144, 646-674

Hanahan D, Weinberg RA, Francisco S (2000): The Hallmarks of Cancer. Cell $\underline{100}, 57-$ 70

Hanisch U-K, Kettenmann H (2007): Microglia: active sensor and versatile effector cells in the normal and pathologic brain. Nat Neurosci $\underline{10}, 1387-1394$

Hauptmann S, Schnalke T (2001): Rudolf Virchows Sicht der malignen Geschwülste. Pathologe 22, $291-295$

Hiraga T, Williams PJ, Ueda A, Tamura D, Yoneda T (2004): Zoledronic acid inhibits visceral metastases in the $4 \mathrm{~T} 1 /$ luc mouse breast cancer model. Clin Cancer Res $\underline{10}$, 4559-4567 
Kielian T, Rooijen N van, Hickey WF (2002): MCP-1 expression in CNS-1 astrocytoma cells: implications for macrophage infiltration into tumors in vivo. $\mathrm{J}$ Neuro-Oncol $\underline{56}, 1$ 12.

Kim J-A, Yamada MK, Nishiyama N, Matsuki N, Ikegaya Y (2003): Mossy fiber pathfinding in multilayer organotypic cultures of rat hippocampal slices. Cell Mol Neurobiol $\underline{23}, 115-119$.

Klemm F: Der Wnt-Signalweg in der Makrophagen induzierten Invasion von Brustkrebszellen. Med. Diss. Göttingen 2010

Koehne $\mathrm{CH}$, Dubois RN (2004): Cox-2 inhibition and colorectal cancer. Semin Oncol $\underline{31}, 12-21$

Kohl A, Dehghani F, Korf HW, Hailer NP (2003): The bisohosphonate clodronate depletes microglial cells in excitotoxically injured organotypic hippocampal slice cultures. Exp Neurol 181, 1-11

Kreutz S, Koch M, Böttger C, Ghadban C, Korf H-W, Dehghani F (2009): 2Arachidonoylglycerol elicits neuroprotective effects on excitotoxically lesioned dentate gyrus granule cells via abnormal-cannabidiol-sensitive receptors on microglial cells. Glia $\underline{57}, 286-294$

Kreutzberg GW (1996): Microglia: a sensor for pathological events in the CNS. Trends Neurosci $\underline{19}, 312-318$

Lee SS, Ahn J-H, Kim MK, Sym SJ, Gong G, Ahn SD, Kim S-B, Kim WK (2008): Brain metastases in breast cancer: prognostic factors and management. Breast Cancer Res Treat $\underline{111}, 523-530$

Leek RD, Harris AL (2002) Tumor-associated macrophages in breast cancer. J Mammary Gland Biol Neoplasia $\underline{7}, 177-189$

Leek RD, Lewis CE, Whitehouse R, Greenall M, Clarke J, Harris AL (1996): Association of macrophage infiltration with angiogenesis and prognosis in invasive breast carcinoma. Cancer Res $\underline{56}, 4625-4629$ 
Lin EY, Nguyen a V, Russell RG, Pollard JW (2001): Colony-stimulating factor 1 promotes progression of mammary tumors to malignancy. J Exp Med 193, 727-740

Ling E, Wong WC (1993): The origin and nature of ramified and amoeboid microglia: a historical review and current concepts. Glia $\underline{7}, 9-18$

Ling EA (1976): Some aspects of ameboid microglia in the corpus callosum and neighbouring regions of neonatal rats. J Anat $\underline{121}, 29-45$

Mantovani A, Sica A, Sozzani S, Allavena P, Vecchi A, Locati M (2004): The chemokine system in diverse forms of macrophage activation and polarization. Trends Immunol 25, 677-686

Mantovani A, Allavena P, Sica A, Balkwill F (2008): Cancer-related inflammation. Nature $\underline{454}, 436-444$

Markovic DS, Glass R, Synowitz M, van Rooijen N, Kettenmann H (2005): Microglia stimulate the Invasiveness of Glioma Cells by Increasing the Activity of Metalloprotease-2. J Neuropathol Exp Neurol $\underline{64}, 754-762$

Matsumura H, Ohnishi T, Kanemura Y, Maruno M, Yoshimine T (2000): Quantitative analysis of glioma cell invasion by confocal laser scanning microscopy in a novel brain slice model. Biochem Biophys Res Commun 269, 513-520

Mousa S (2008): Cell adhesion molecules: potential therapeutic \& diagnostic implications. Mol Biotechnol $\underline{38}, 33-40$

Nakamura $Y$ (2002): Regulating factors for microglial activation. Biol Pharm Bull $\underline{25}$, 945-953

Niehrs C (2006): Function and biological roles of the Dickkopf family of Wnt modulators. Oncogene $\underline{25}, 7469-7481$

Padalecki SS, Guise TA (2002): Actions of bisphosphonates in animal models of breast cancer. Breast Cancer Res 4, 35-41 
Paget S (1889): The distribution of secondary growths in cancer of the breast. Lancet 1889, 23.3., 571-573.

Pestalozzi BC (2009): Brain metastases and subtypes of breast cancer. Ann Oncol 20, 803-805

Podleschny MC: Untersuchung zum Einfluss von Wnt 5a und Dkk-1 auf das Migrationsverhalten von Mamma-Karzinom Zelllinien. Bachelorarbeit Molecular Medicine Göttingen 2006

Pollard JW (2009): Trophic macrophages in developement and disease. Nat Rev Immunol $\underline{9}, 259-270$

Posner JB (1992): Management of brain metastases. Rev Neurol 148, 477-487

Poritz LS, Garver KI, Tilberg AF, Koltun WA (2004): Tumor necrosis factor alpha disrupts tight junction assembly. J Surg Res $\underline{116}, 14-18$

Priller J, Flugel A, Wehner T, Boentert M, Haas CA, Prinz M, Fernandez Klett F, Prass K, Bechmann I, de Boer BA, Frotscher M, Kreutzberg GW, Persons DA, Dirnagl U (2001): Targeting gene-modified hematopoetic cells to the central nervous system: use of green fluorescent protein uncovers microglial engraftment. Nat Med $\underline{7}, 1356-1361$

Pukrop T, Klemm F, Hagemann T, Gradl D, Schulz M, Siemes S, Trumper L, Binder C (2006): Wnt 5 a signaling is critical for macrophage-induced invasion of breast cancer cell lines. Proc Natl Acad Sci U S A 103,5454 - 5459

Pukrop T, Dehghani F, Chuang H-N, Lohaus R, Bayanga K, Heermann S, Regen T, Van Rossum D, Klemm F, Schulz M, Siam L, Hoffmann A, Lorenz T, Stadelmann C, Bechmann I, Hanisch U-K, Binder C (2010): Microglia promote colonization of brain tissue by breast cancer cells in a Wnt-dependent way. Glia $\underline{58}, 1477-1489$

Robinson-Smith TM, Isaacsohn I, Mercer CA, Zhou M, van RN, Husseinzadeh N, Mc Farland-Mancini MM, Drew AF (2007): Macrophages mediate inflammation-enhanced metastasis of ovarian tumors in mice. Cancer Res $\underline{67}, 5708-5716$ 
Roggendorf W, Strupp S, Paulus W (1996): Distribution and characterization of microglia /macrophages in human brain tumors. Acta Neuropathol $\underline{92}, 288-293$

Rollins BJ (1996): Monocyte chemoattractant protein 1: a potent regulator of monocyte recruitment in inflammatory disease. Mol Med Today 2, $198-204$

Schwartz M, Butovsky O, Brück W, Hanisch U-K (2006): Microglial phenotype: is the commitment reversible? Trends Neurosci $\underline{29}, 68-74$

Sica A, Schioppa T, Mantovani A, Allavena P (2006): Tumour-associated macrophages are a distinct M2 polarised population promoting tumour progression: potential targets of anti-cancer therapy. Eur J Cancer $\underline{42}, 717$ - 727

Sliwa M, Markovic D, Gabrusiewicz K, Synowitz M, Glass R, Zawadzka M, Wesolowska A, Kettenmann H, Kaminska B (2007): The invasion promoting effect of microglia on glioblastoma cells is inhibited by cyclosporin A. Brain $\underline{130}, 476-489$

Sofroniew MV (2005): Reactive astrocytes in neural repair and protection. The Neuroscientist 11, 400-407

Sozzani S, Locati M, Zhou D, Rieppi M, Luini W, Larmorte G, Bianchi G, Polentarutti N, Allavena P, Mantovani A (1995): Receptors, signal transduction and spectrum of action of monocyte chemotactic protein-1 and related chemokines. J Leukoc Biol $\underline{57}, 788-794$

Stoppini L, Buchs P, Muller D (1991): A simple method for organotypic cultures of nervous tissue. J Neurosci Methods $\underline{37}, 173-182$

Streit WJ (2001): Microglia and Macrophages in the developing CNS. Neurotoxicol $\underline{22}$, 619-124

Streit WJ, Xue Q-S (2009): Life and death of microglia. J Neuroimmune Pharmacol $\underline{4}$, 371-379

Streit WJ, Graeber MB, Kreutzberg GW (1988): Functional plasticity of microglia: a review. Glia 1, 301-307 
Streit WJ, Walter S, Pennell N (1999): Reactive microgliosis. Progress in Neurobiology 57, 563-581

Streit WJ, Conde JR, Fendrick SE, Flanary BE, Mariani CL (2005): Role of microglia in the central nervous system 's immune response. Neurol Res $\underline{27}, 685-691$

Tuomela JM, Valta MP, Väänänen K, Härkönen PL (2008): Alendronate decreases orthotopic PC-3 prostate tumor growth and metastasis to prostate-draining lymph nodes in nude mice. BMC Cancer $\underline{28} ; 8: 81$

Ulrich T, Jain A, Tanner K, MacKay JL, Kumar S (2010): Probing cellular mechanobiology in three-dimensional culture with collagen-agarose matrices. Biomaterials $\underline{31}, 1875-1884$

Villeneuve J, Tremblay P, Vallieres L (2005): Tumor necrosis factor reduces brain tumor growth by enhancing macrophage recruitement and mircrocyst formation. Cancer Res $\underline{65}$, 3928-3936

Wang F, Graham WV, Wang Y, Witkowski ED, Schwartz BT, Turner JR (2005): Interferon-gamma and tumor necrosis factor-alpha synergize to induce intestinal epithelial barrier dysfunction by up-regulating myosin chain light kinase expression. Am J Pathol 166, 409-419

Watters JJ, Schartner JM, Badie B (2005): Microglia function in brain tumors. J Neurosci Res $\underline{81}$, 447-455

Wesolowska A, Kwiatkowska A, Slomnicki L, Dembinski M, Master A, Sliwa M, Franciszkiewicz K, Chouaib S, Kaminska B (2008): Microglia-derived TGF-beta as an important regulator of glioblastoma invasion - An inhibition of TGF-beta-dependent effects by shRNA against human TGF-beta type II receptor. Oncogene 27, 918-930

Yang J, Weinberg R (2008): Epithelial-mesenchymal transition: at the crossroads of development and tumor metastasis. Dev Cell $\underline{14}, 818-829$

Yap S, Brieher WM, Gumbiner BM (1997): Molecular and functional analysis of cadherin-based adherens junctions. Annu Rev Cell Dev Biol 13, 119-146 
zur Hausen, H (2008): Papillomaviruses - to Vaccination and Beyond. Biochemistry Mosc. $\underline{73}, 498-503$ 


\section{Danksagung}

Herzlich möchte ich mich bei Frau Prof. Claudia Binder für Ihre Betreuung, bereichernden Diskussionen und Hilfestellungen bedanken. Gleichsam danke ich der gesamten Arbeitsgruppe von Frau Prof. Binder, insbesondere PD Dr. Tobias Pukrop, der mein Projekt betreute und mir zur Seite stand, Matthias Schulz, der mich die grundlegenden Labortechniken lehrte, Eugenia Chuang, Julia Schoenen und Dr. Christina Charlotte Dicke für die freundschaftliche Begleitung und die sehr schöne gemeinsame Zeit im Labor. Prof. Dieter Kube danke ich für die Hodgkin-LymphomZelllinie L428, die er mir freundlicherweise zur Verfügung stellte. Besonders herzlich möchte ich mich zudem bei Prof. Ingo Bechmann, Prof. Faramarz Dehghani, Chalid Ghadban und Dr. Carolin Prodinger bedanken mit deren Hilfe ich die Methode der Organotypischen Hirnschnittkultur erlernen konnte. Zuletzt gilt mein Dank meinen Eltern Maria Lohaus und Prof. Ludger Lohaus sowie meinen Geschwistern Lukas und Theresa, die meine Arbeit nie müde wurden zu lesen und mich mit hilfreichen Anmerkungen und redaktionellen Tipps immer unterstützten. 


\section{Lebenslauf}

Am 13.08.1981 wurde ich als Tochter von Maria Lohaus, geb. Wissing, und Prof. Ludger Lohaus in Gladbeck geboren. Nach den Grundschuljahren von 1988-1992 an der St. Johannes Grundschule in Gladbeck, besuchte ich ab 1992 das Ratsgymnasium in Gladbeck. Während der gymnasialen Schulzeit absolvierte ich Sprachaufenthalte in England, den USA und Frankreich. Meine schulische Ausbildung schloss ich 2001 mit dem Erwerb der allgemeinen Hochschulreife mit einer Durchschnittsnote von 1,5 ab. Im Anschluss begann ich ein Studium der Wirtschaftswissenschaften an der LeibnizUniversität in Hannover, wo ich das Vordiplom erwarb. Daraufhin wechselte ich im Jahre 2004 für ein Studium der Humanmedizin an die Georg-August-Universität in Göttingen. Während der klinischen Semester absolvierte ich Famulaturen am Institute for Pigmentary Disorder der University of Bradford, England sowie am Centre René Huguenin, St. Cloud, Paris. Während meines Praktischen Jahres verbrachte ich ein Tertial am CHU Haut-Lévêque der Université Victor Segalen Bordeaux II. Ein weiteres Tertial absolvierte ich am CHU de Fort de France, Hôpital P. Zobda Quitman, Martinique. Neben dem Erwerb guter Sprachkenntnisse in Französisch und Englisch konnte ich durch die vielen intensiven und bereichernden Aufenthalte einen Einblick in die medizinische Versorgung in England und Frankreich erhalten. Im Anschluss an das Praktische Jahr schloss ich mein Studium der Humanmedizin mit dem 2. Abschnitt der Ärztlichen Prüfung ab (1. Abschnitt der Ärztlichen Prüfung, Note: sehr gut; 2. Abschnitt der Ärztlichen Prüfung, Note: gut). Während der Studienzeit wurde ich als Stipendiatin des Begabtenförderungswerkes "Cusanuswerk" gefördert, welches mich besonders durch die ideelle Förderung sehr geprägt hat. Seit 2011 bin ich als Assistenzärztin in der Abteilung Hämatologie/Onkologie der Universitätsmedizin Göttingen tätig. Meine Dissertation realisierte ich in der Arbeitsgruppe von Frau Prof. Claudia Binder, Abteilung Hämatologie und Onkologie der UMG. Teile dieser Arbeit konnte ich bei einem Forschungsaufenthalt in der Arbeitsgruppe von Prof. Ingo Bechmann der Dr. Senckenbergischen Anatomie der Universität Frankfurt a. M. umsetzen. Während meiner Dissertation wurde ich durch das Promotionsstipendium "Gö4med" der Universitätsmedizin Göttingen unterstützt. In meiner freien Zeit beschäftige ich mich mit Sologesang im Bereich Jazz, Chanson und Liedgesang, ich trete mit verschiedenen Pianisten und Jazzcombos auf und engagiere mich musikalisch in der kath. Kirche, z.B. für Körperspender in der Anatomie. 